Illinois State University

ISU ReD: Research and eData

Theses and Dissertations

$10-24-2018$

\title{
The Plight Of Wage-Earning Women In Peoria, 1905-1915
}

Cheryl Kay Fogler

Illinois State University, ckfogler@gmail.com

Follow this and additional works at: https://ir.library.illinoisstate.edu/etd

Part of the United States History Commons

\section{Recommended Citation}

Fogler, Cheryl Kay, "The Plight Of Wage-Earning Women In Peoria, 1905-1915" (2018). Theses and Dissertations. 1021.

https://ir.library.illinoisstate.edu/etd/1021

This Thesis is brought to you for free and open access by ISU ReD: Research and eData. It has been accepted for inclusion in Theses and Dissertations by an authorized administrator of ISU ReD: Research and eData. For more information, please contact ISUReD@ilstu.edu. 
THE PLIGHT OF WAGE-EARNING WOMEN IN PEORIA, 1905-1915

\section{CHERYL KAY FOGLER}

117 Pages

This thesis examines the conditions of wage-earning women in Peoria, Illinois, during the first two decades of the twentieth century. I present the plight of wage-earning women as well as the well-intended efforts of both local and national crusaders who helped the working women of Peoria survive and in some cases overcome hardships.

KEYWORDS: working-class women; wages; employment; progressive; reform; vice; prostitution, Peoria 
THE PLIGHT OF WAGE-EARNING WOMEN IN PEORIA, 1905-1915

\author{
CHERYL KAY FOGLER
}

\begin{abstract}
A Thesis Submitted in Partial Fulfillment of the Requirements for the Degree of

MASTER OF SCIENCE

Department of History

ILLINOIS STATE UNIVERSITY
\end{abstract}


Copyright 2018 Cheryl Kay Fogler 
THE PLIGHT OF WAGE-EARNING WOMEN IN PEORIA, 1905-1915

\author{
CHERYL KAY FOGLER
}

COMMITTEE MEMBERS:

Kyle Ciani, Chair

Linda Clemmons

Amy Wood 


\section{ACKNOWLEDGMENTS}

Writing this thesis was a very rewarding experience both professionally and personally thanks to the guidance of my very talented thesis committee. I would like to express my sincere gratitude to my thesis advisor Dr. Kyle Ciani for her time, support, encouragement and neverending faith in me. Dr. Ciani's knowledge and passion for women's history inspired this thesis and I will be forever grateful for her investment in me. I am indebted to my committee members, Dr. Linda Clemmons and Dr. Amy Wood, for their time, patience, and intellectual contributions to this work. I greatly respect their work as historians and am honored they sat on this committee.

I am deeply grateful to Christopher Farris from the Peoria Public Library whose expertise and love of Peoria's history was invaluable in my research. His passion for research and ability to rise probing questions made my research an adventure. Thanks to Elizabeth Bloodworth at Bradley University's Cullom-Davis Library for bringing to light the many treasures of the Special Collections Center. A special thanks to Vanette Schwartz, Social Sciences Librarian at Illinois State University, for her many years of guidance and encouragement.

This work would not have been possible without the support of my family and friends. My deepest appreciation goes to Angela Engel, my friend and colleague, whose flexibility made all my days of research and writing possible. Her uncanny ability to make me laugh eased many worries and got me back on track. I owe my deepest gratitude to my husband, Matthew, whose faith and support never wavered. To my sons, parents, sisters, nieces, and neighbors thanks for being my cheer squad and believing I could do this, especially on those days I did not. Funny notes, home cooked meals, and hugs meant more to me than I can express. Thanks to each of you!

C.K.F. 


\section{CONTENTS}

Page

ACKNOWLEDGMENTS

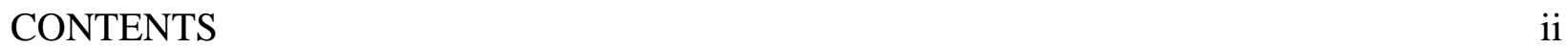

CHAPTER I: INTRODUCTION 1

CHAPTER II: WAGE-EARNING IN PEORIA 11

$\begin{array}{ll}\text { Demographics of Peoria } & 12\end{array}$

Types of Employment 16

Problems of Low Wages $\quad 31$

CHAPTER III: CHALLENGES OF WAGE-EARNING WOMEN 38

$\begin{array}{ll}\text { Desertion } & 40\end{array}$

$\begin{array}{ll}\text { Divorce } & 44\end{array}$

$\begin{array}{ll}\text { Mothers' Pensions } & 48\end{array}$

$\begin{array}{ll}\text { Domestic Violence } & 50\end{array}$

$\begin{array}{ll}\text { Violence against Women } & 58\end{array}$

$\begin{array}{ll}\text { Alcohol Abuse } & 61\end{array}$

$\begin{array}{ll}\text { Illegitimacy } & 63\end{array}$

Women Working in the Red-Light District 65

CHAPTER IV: PROGRESSIVE-ERA REFORMERS IN PEORIA 71

$\begin{array}{ll}\text { Community Organizations in Peoria } & 72\end{array}$

Peoria Women's Civic Federation $\quad 75$

$\begin{array}{ll}\text { Rescue Homes } & 81\end{array}$

Young Women’s Christian Association $\quad 87$ 
State Initiatives

CONCLUSION

104

BIBLIOGRAPHY

108 


\section{CHAPTER I: INTRODUCTION}

In the first two decades of the twentieth century, women in the United States entered the workforce in unprecedented numbers. The conditions driving their entry included greater access to wage labor due to economic and social changes caused by industrial and commercial enterprises. Historians have studied these working women extensively, especially in terms of the political, economic, and policy reforms that affected how these women experienced the changes. Most of these studies focus on cities that witnessed expansive population shifts due to immigration or internal migration, such as New York, Boston and Chicago. ${ }^{1}$ However, smaller cities also experienced these shifts, and they too need studied to assess how regional attitudes changed the national conversation about the difficulties that working women faced. ${ }^{2}$

This thesis examines the conditions of wage-earning women in Peoria, Illinois, during the first two decades of the twentieth century. Despite its presence as the second largest city in Illinois in 1900, no one has yet studied the experiences of working women in Peoria. Like their working sisters across the country, these women struggled to earn a living despite growth in employment opportunities. Unfortunately, most of these opportunities were limited to low paying positions with no promise of betterment. Employers assumed the wages they paid women supplemented those of a male member of the household whether a husband or a father. Most women did not earn enough from their individual wages to support themselves and their

\footnotetext{
${ }^{1}$ Works that examined wage-earning women in large cities at the turn of the twentieth century include Leslie Woodcock Tentler, Wage-Earning Women Industrial Work and Family Life in the United States, 1900 -1930 (New York: Oxford University Press, 1979); Joanne J. Meyerowitz, Women Adrift: Independent Wage Earners in Chicago, 1880-1930 (Chicago: The University of Chicago Press, 1988); Carolyn Strange, Toronto's Girl Problem: The Perils and Pleasures of the City, 1880-1930 (Toronto: University of Toronto Press, 1995); and Kathy Peiss, Cheap Amusement: Working Women and Leisure in Turn-of-the-Century New York (Philadelphia: Temple University Press, 1986).

${ }^{2}$ Nancy A. Hewitt, Southern Discomfort: Women's Activism in Tampa, Florida, 1880s-1920s (Urbana: University of Illinois Press, 2001.
} 
dependents and many were compelled to seek alternative means to earn money or send their children into the workforce at a young age.

Wage-earning women living and working in cities across the country emerged as a social problem around the turn of the century. As women left the domestic sphere and entered the workforce, they competed with men for jobs and pay. Society struggled with the impact of this on families and the instability it created in the ideal home structure, where men were the primary breadwinners and women performed domestic and childrearing duties in the home. Independent working women were caught in a double bind. They needed to work to provide for themselves or their dependents yet the separate spheres culture and the urban environment did not support it. How these women managed in the city concerned many Progressive reformers and they worked for measures to support independent working-class women and stabilize the home. I present the plight of wage-earning women as well as the well-intended efforts of both local and national crusaders who helped the working women of Peoria survive and in some cases overcome hardships. Peoria's reformers and social workers were on the forefront of creating and implementing measures that attacked major social issues at the turn of the twentieth century..

This thesis uses agency reports such as Police Matron annual reports, financial reports from the City of Peoria Comptroller, as well as reports from the Illinois Board of State Commissioners of Public Charities. Correspondence and records from national organizations such as the Y.W.C.A. and the Traveler's Aid Society offer detailed accounts of aid to individual women as well as monthly and yearly summaries. Statistics from the Department of Commerce and Labor Bureau of the Census reports as well as the annual reports of the Illinois Free Employment Offices illustrate the number of employable women in Peoria and types of employment available to them. Newspaper stories note the tenor of the city while social 
organizational minutes target concrete solutions. Reports from the Illinois Senate Vice Committee, the Chamber of Commerce, and individual merchants illustrate the concern of the city leaders to civic problems. This wide range of sources allowed me to explore the strategies working women used in Peoria to support their families and the reactions by reformers to these actions.

Peoria proved attractive to working-class families because it offered a wide variety of jobs for both skilled and unskilled workers, and presented opportunities for self-employment. Jobs in factories, commercial offices, hotels, restaurants, and the large shopping district that supported the city's convention center all gave women an opportunity to earn wages. Women could also support their families by opening boarding houses to accommodate the workers migrating into the city. However, along with these trends, came struggles for workers, especially women who faced the problem of supporting themselves and their children.

Beginning in the 1970s, historians have examined the social problems surrounding wageearning women and the culture that emerged among them during the late nineteenth and early twentieth centuries. They focused on young, single, wage-earning women whose entry into the workforce challenged societal notions of women's roles and sexuality. Leslie Woodcock Tentler was the first historian to provide an overview of these issues. Tentler explored the experiences of female factory workers in major industrial cities in the East and Midwest mainly Boston, New York, Philadelphia, and Chicago. ${ }^{3}$ Her study explored their experiences at work, in the home, and in the industrial neighborhoods. She chose to study factory workers over domestic or clerical workers because factory work seemed to be the most typical line of work for working-class women during the early decades of the twentieth century. By relying heavily on the reports of

\footnotetext{
${ }^{3}$ Tentler, Wage-Earning Women.
} 
middle-class, social workers and government investigators, Tentler concluded that industrial employment reinforced female dependence on family through low wages and limited job opportunities. It strengthened sex-segregated roles within the home and bolstered women to make traditional life choices. Tentler's analysis is the first to highlight the critical involvement of women's labor to the family economy.

Carroll Smith-Rosenberg examined similar conflicts surrounding working women that arose in the late nineteenth century. Her work is important to this study as she analyzes the cultural mechanisms that men and women developed to handle the disruptions resulting from rapid socioeconomic changes in the nineteenth century. These mechanisms shaped how reformers reacted to wage-earning women in the early twentieth century. Smith-Rosenberg concluded that as young working women challenged their traditional public and political roles they become the ultimate symbol of social danger and disorder in a world that accepted women's independence. Her analysis of the new woman addresses progressive reformers' fears that women in the work force devalued femininity and challenged traditional ideals by assuming the manly duty of familial support. ${ }^{4}$

In the 1980s and 1990s, historians began to focus on wage-earning women at the turn of the twentieth century in specific cities such as Chicago and New York City. These cities are distinctive yet studies of working women in them have emphasized national trends of the struggles facing urban working women. Historians who have studied working people in these larger cities relied on the copious records of social agencies. In addition, contemporary studies

\footnotetext{
${ }^{4}$ Carroll Smith-Rosenberg, Disorderly Conduct Visions of Gender in Victorian America (New York: Alfred A. Knopf, 1985), 181.
} 
on immigrants in those metropolises yielded interviews and records that historians used in understanding working-class culture..$^{5}$

One of the most important of these urban case studies is Joanne Meyerowitz's study of working women in Chicago whom she called "women adrift." Meyerowitz showed how they created their own culture and challenged Victorian ideals regarding women. ${ }^{6}$ Meyerowitz expanded Tentler's spotlight on factory workers by focusing on the social and support networks that women adrift accessed to become self-sufficient. She broadened Smith-Rosenberg's analysis of the revolution of sexual norms and highlighted the extent of agency that independent women in the city actually exerted over their own sexuality. Kathy Peiss similarly explored the agency of young working women in New York by studying their leisure activities revolving around new commercialized, urban pleasures, which middle-class reformers deemed deeply threatening to the traditional moral order. Peiss argues that reformers' attempts to make commercial amusements more respectable ultimately came to change middle-class culture. ${ }^{7}$

A number of historians took these findings and broadened the research by focusing on how wage-earning women challenged the separate spheres ideology. The morals of the young women who appeared to prefer factory, clerical, or sales work to domestic service jobs became a source of concern for state-appointed experts and moral reformers alike. Scholars have examined various cities to uncover the effects of "the girl problem" on civic life. In her study of Toronto, Canada, Carolyn Strange concluded that the single, sexually assertive wage-earning woman

\footnotetext{
${ }^{5}$ For more on immigrant working-class women see Elizabeth Alice Clement, Love for Sale: Courting, Treating, and Prostitution in New York City, 1900-1945 (Chapel Hill: University of North Carolina Press, 2006), Mary E. Odem, Delinquent Daughters: Protecting and Policing Adolescent Female Sexuality in the United States, $1885-1920$ (Chapel Hill: The University of North Carolina Press, 1995), and Sharon Wood, The Freedom of the Streets: Work, Citizenship, and Sexuality in a Gilded Age City (Chapel Hill: University Of North Carolina Press, 2005).

${ }^{6}$ Meyerowitz, Women Adrift.

${ }^{7}$ Kathy Peiss, Cheap Amusements: Working Women and Leisure in New York City, 1880 to 1920 (Philadelphia: Temple University Press, 1986).
} 
came to symbolize modern urban life. ${ }^{8}$ Life in the city meant pursuit of worldly goods and sometimes the pursuit came at great cost. While living and working in the city, the modern woman was no longer restricted to only performing domestic duties or to sitting at home while the male members of the household enjoyed the pleasures of the city. The modern woman enjoyed all the city had to offer. ${ }^{9}$

Elizabeth Alice Clement continued this analysis of working-class notions of sexual morality by examining the reasons why working-class women slipped into prostitution and how working-class communities regarded the profession at the turn of the twentieth century. Like Strange, she devoted much of her book to solutions developed by the middle-class to the perceived threat of working-class morals. Clement claimed most women entered prostitution to provide for family members and to maintain family ties because of their inability to earn a living wage. ${ }^{10}$ Working-class communities understood this plight and often ignored certain aspects of urban vice.

Other scholars have focused on the social-order policies that Progressive reformers used to control urban vice and have claimed that reformers did not seek to eliminate vice altogether but simply wanted to reduce its worst effects. Mara L. Keire contended that efforts to reduce prostitution and drinking actually backfired and the unintended outcome was a sporting class culture that stimulated the economic success of red-light districts. ${ }^{11}$ These districts became an important element of the urban experience and blurred the lines between propriety and immorality.

\footnotetext{
${ }^{8}$ Strange, Toronto's Girl Problem, 212.

${ }^{9}$ See also Ruth Alexander, The "Girl Problem": Female Sexual Delinquency in New York, 1900-1930 (Ithaca: Cornell University Press, 1995.

${ }^{10}$ Clement, Love For Sale, 76.

${ }^{11}$ Mara L. Keire, For Business and Pleasure: Red-light Districts and the Regulation of Vice in the United States, 1890-1933 (Chapel Hill: University of North Carolina Press, 2011).
} 
Vanessa May likewise has examined the failure of certain reform efforts in her study of domestic servants in New York. Domestic service was the largest sector of women's employment in the late nineteenth and early twentieth centuries. The "servant problem" was a contentious public issue that invaded the very private sphere of the middle-class home. Most disagreements between the middle-class employers and domestics centered around poor wages, hours on the job, and workers' personal autonomy. ${ }^{12}$ She concluded that reform efforts for the servant girl problem failed for several reasons. First, middle-class reformers could not see beyond their own needs to help the working-class women suffering in their own homes. Second, domestics failed to make their plight visible in the world of labor relations and therefore could not get legislators to regulate working conditions for domestic service. May's analysis of the servant problem is important to this thesis, as domestic work was the most typical line of work available to women in Peoria during the early decades of the twentieth century.

Recent scholarship has highlighted the importance of studying medium sized communities. Sharon Wood examined women with "respectable" employment and women who earned their wages through prostitution in Davenport, Iowa. Located along the Mississippi River, Davenport represents a community that underwent tremendous change in the Progressive Era due to consumer energy driven by its location. She determined that working women in Davenport collaborated in mutually beneficial endeavors to ease some of their financial woes but they also labored to eliminate the stigma associated with working outside of the home. Wood explored how wage-earning women experienced life in the city but also how they helped shape public

\footnotetext{
${ }^{12}$ Vanessa H. May, Unprotected Labor Household Workers, Politics, and Middle-Class Reform in New York, 18701940 (Chapel Hill: University of North Carolina Press, 2011), 71.
} 
policy. Her in-depth study of prostitution in Davenport focused on civic efforts to regulate the trade as well as reformer's attempts to place wayward girls into reformatory institutions. ${ }^{13}$

This thesis will follow a similar approach to Wood and investigate the experiences of wage-earning women in the urban setting of Peoria, Illinois. Its three chapters will outline the importance of Peoria in understanding the working-class woman's experience as a wage-earner, a daughter, and as a wife and mother. The first chapter establishes the framework of why a study of Peoria is important to understanding the experiences of wage-earning women at the turn of the century by outlining the domestic demography of Peoria, including the employment, educational, civic, and leisure opportunities available to women in Peoria. Its size, central locality within the state and the Midwest, abundance of employment and entertainment opportunities, and access to both rail and waterways makes Peoria an important site to study. Peoria was a midsized city, in an ideal location, with lots to offer its residents and visitors.

Even though Peoria offered many opportunities to both middle-class and working women, many women faced traumatic situations that forced them to make uncomfortable decisions about how they could survive. Chapter two outlines some of the problems women in Peoria faced both in the domestic and public realms. A review of newspaper articles shows that journalists regularly reported on episodes of domestic violence, and often highlighted how poverty and alcohol abuse escalated the violence. Government analyses highlight the numerous divorce petitions that began appearing in Peoria courts, and state commissions began to document the many social problems growing in the city. They found that many of these problems were connected to Peoria's growing reputation as the "whiskey capital of the world." Saloons flourished despite civic leaders' efforts to impose costly licenses and fines, and prostitutes

\footnotetext{
${ }^{13}$ Sharon Wood, The Freedom of the Streets: Work, Citizenship, and Sexuality in a Gilded Age City (Chapel Hill: University Of North Carolina Press, 2005).
} 
became cemented in the city landscape. City leaders bemoaned the fact that madams owned and operated brothels in the city and engaged scores of employees to service customers. Many wageearning women endured the cycle of poverty throughout their entire lives because they came from single parent homes, entered the workforce at an early age, and even as adult wage-earners could not earn a living wage. This chapter reviews the familial traumas that emerged in Peoria and assesses some of the situations that kept working-class women captive to a life of poverty.

Working women in Peoria did not have to face these struggles alone as civic leaders and social reformers alike recognized their hardships and attempted to provide some respite. Chapter three considers the measures taken by state and local leaders to better the condition of wageearning women in Peoria. Reformers and civic leaders understood circumstances for wageearning women in Peoria necessitated change, yet their solutions reflected deep-rooted separate spheres and maternalism ideology. The Illinois Senate Vice Commission spent three years investigating the conditions that threatened the goodness of the home and proposed remedial measures to help rectify the plight of working women but it took twenty or more years for many of their recommended solutions to materialize.

The Y.W.C.A. of Peoria partnered with many local and national civic organizations to provide food, shelter, safety, and social activities for wage-earning women. Charitable institutions such as the Florence Crittenton Home, Home of the Good Shepherd, and Home of the Friendless collaborated with the Peoria Police Matron and other civic leaders to rehabilitate wayward girls. This chapter explores the many services available to wage-earning women but also seeks to understand why these women continued to suffer despite the myriad of assistance programs available to them. 
Through the testimonies in the vice commission we see that issues plaguing wage-earning women did not all stem from the vice industry. Many women who found themselves working in brothels ended up there as a last resort because they could not support themselves through legitimate means. Desertion, divorce, and abuse created poverty and instability in the home that forced women into a situation where they had to get a job. This created more uncertainty, insecurity, and anxiety for women pushed to work outside of the home. In particular, the lack of childcare and time for domestic duties led to accusations of neglect and abuse by social reformers. Very limited opportunities existed for women to earn money in the home and many of those options put them at risk from a moral standpoint, making them ineligible for state support through a mothers' pension. Despite charitable organizations interacting with these women since the 1890s, social reform efforts did not achieve the desired result in Peoria of alleviating the woes of the wage-earning woman.

This thesis does not seek to address the full effects of progressive reforms on the working class community in Peoria. Instead, it shows how the living and working conditions of wageearning women in the state's second largest city influenced those larger conversations among progressive reformers about the difficulties that working women faced. Local and state reformers realized the plight of working girls and women in cities like Peoria and worked locally, regionally, and nationally to make their lives better. But the lives of the women examined in this study expose the cyclical effects of poverty on this group. Many women entered the workforce out of necessity — some in their childhoods, some as deserted wives and mothers — but low wages and poor working conditions kept most of them impoverished in spite of their wage earning. 


\section{CHAPTER II: WAGE-EARNING IN PEORIA}

In 1916, during his testimony before the Illinois Senate Vice Committee, Richard Heidrick, president of the Peoria Cordage Company, commented on the types of female employees that his manufacturing company employed. He explained that because they had limited schooling, “A great many of them, I suppose, could not occupy any very high position, probably nothing any higher than they are now filling," which primarily involved dirty and tedious machinery work. He emphasized, "If a girl could do much better than that, I don't believe we could employ her at what we do." ${ }^{14}$ Heidrick attempted to justify the low wages paid to female factory workers in Peoria, which were $\$ 6.00$ a week, by claiming his employees did not need to purchase nice clothes to work in the factory. He continued, "The ordinary clothes, half worn out, that she would have to throw away, in some occupations, she can wear them out down there until they are rags." 15 The Vice Committee interrogated Heidrick, as well as managers from the Larkin Company, F. W. Woolworth \& Company, and Schipper \& Block regarding the wages paid to their female employees.

Progressive reformers in Illinois, and across the nation, were deeply concerned about the morality of Americans and the stability of the home. The growing presence of women in the paid workforce altered ideals of separate spheres and the sexual division of labor. More and more women in the early twentieth century served as primary providers for the family, but because their wages did not rise to the level of men's, it was difficult if not impossible for them to support themselves or children under their care. Civic leaders and reformers feared that many of these underpaid workers resorted to prostitution to support themselves and their dependents. The

\footnotetext{
${ }^{14}$ Report of the Senate Vice Committee Created under the Authority of the Senate of the Forty-ninth General Assembly as a Continuation of the Committee Created under the Authority of the Senate of the Forty-Eighty General Assembly (Chicago: Allied Printing, 1916), 288.

${ }^{15}$ Report of the Senate Vice Committee, 287.
} 
investigation of the Senate Vice Committee helped state leaders assess correlations between low wages and prostitution but it also revealed the pervasive cultural belief that women were not expected to be a home's primary provider. Through the testimony of wage-earning women we see the insecurity many of these women faced their entire lives due to social problems such as desertion, divorce, and alcoholism, and the barriers they had to overcome to survive in the city.

This chapter uses reports from the Illinois Senate Vice Committee and the Bureau of Labor Statistics to understand the employment opportunities for wage-earning women in Peoria at the turn of the century. This evidence shows that Peoria attracted female workers who were unskilled and largely illiterate. Leaders in Illinois were concerned about what they believed to be the deteriorating condition of the family home, which they connected to an increase in businesses stemming from the vice industry. State leaders commissioned a committee to study the extent of vice and to propose a comprehensive plan to correct the effects of immoral behavior. During the process, the extensive red-light district along the Peoria riverfront became highlighted and many business leaders and social reformers became aware of the realities facing the working-class community.

\section{DEMOGRAPHICS OF PEORIA}

The size of Peoria at the turn of the century, the composition of its residents, and the abundance of employment opportunities provide a window into the struggles of wage-earning women in the early twentieth century. Peoria was not a boomtown in the early twentieth century, but its population was steadily growing. The population grew 19.3 percent between 1900 and 1910, making it the second largest city in Illinois at 67,000 . It was also a predominantly white community; 97.6 percent of its residents were listed in the federal census as white with the largest percentage of its foreign-born population coming from Germany or Ireland. Only 2.3 
percent of residents were African American. ${ }^{16}$ A city of this size offered a variety of

opportunities for men and women seeking employment or entertainment. The cluster of German

and Irish immigrants in Peoria added to the character of the city, providing a large blue-collar

workforce and experts in brewing and distilling. The importance of beer in the German culture

bolstered both the manufacture and consumption of alcohol, and German-owned breweries such

as Anheuser Busch and Pabst operated successfully in Peoria.

Peoria had an even mix of male and female residents, but a remarkably high percentage -

fifty percent - were unmarried. ${ }^{17}$ When compared to other cities in Illinois with a population over

25,000 , the city had below the average percentage of married women and had the second highest

percentage of divorced women. ${ }^{18}$ What do these statistics tell about Peoria and why are they

important to the study of working-class women? The census statistics illustrate that Peoria had an

abundance of unmarried women who needed to work to support themselves and possibly

dependents. According to historian Linda Gordon, single mothers were more likely than mothers

from a two-parent household to work outside of the home, and a mother's employment was often

\footnotetext{
${ }^{16}$ Percentages were calculated from data presented in the Department of Commerce and Labor and Bureau of the Census, Thirteenth Census of the United States Taken in the Year 1910 Statistics for Illinois, 636. The white population can be segregated as follows: 54.7 percent native white, 20.8 percent native white of a foreign or mixed parentage, and 13.2 percent foreign-born white. The majority of foreign-born whites were born in Germany and Ireland at 42.4 percent and 11.7 percent respectively.

${ }^{17}$ Department of Commerce and Labor and Bureau of the Census, Thirteenth Census of the United States Taken in the Year 1910 Statistics for Illinois. 51.3 percent of residents were male and 48.7 percent were female. Forty-eight percent of men were unmarried and 45 percent of women. When compared to other cities in Illinois with a population over 25,000 (Aurora, Joliet, Bloomington, Rockford, Quincy, East St. Louis, Elgin, Springfield, Decatur, and Danville), Peoria had one of the lowest percentages of females in a male to female comparison and was below the median of 50.4 percent. I counted single, widowed, and divorced individuals as unmarried. Peoria contained a slightly higher population of single men than other cities. It had the highest percent of divorced men, the second highest percent of widowed men, and the lowest percent of married men amongst other cities.

${ }^{18}$ Department of Commerce and Labor and Bureau of the Census, Thirteenth Census of the United States Taken in the Year 1910 Statistics for Illinois. Only Quincy, Elgin, and Bloomington had lower percentages of married women but only slightly at 51.5, 51.6, and 53.2 respectively. The percent of divorced women in Peoria was $1.4 \%$. Danville had the highest amount of divorced women at $1.5 \%$.
} 
blamed for child abuse, neglect, and delinquency. ${ }^{19}$ This situation troubled Peoria's male leaders who were upper or middle-class and probably the sole providers in their household.

Life at the turn of the century was very different for middle-class and working-class women, especially if they were mothers. Historian Lisa Fine claims that, due to the prominent ideals of separate spheres and sexual division of labor, women who worked outside of the home had to explain the reasons for their work. ${ }^{20}$ Under the separate spheres ideal, husbands were expected to be the primary providers for the family, and most of the time their steady wages reflected that social role. Wives were to complement the activities of the husband by tending to the home and children. Members of the middle-class believed this model offered stability to both the family and society. Yet, historian Alice Kessler-Harris has explained, families of unskilled workers often times found it impossible to survive on the wages of a single wage earner, which forced wives and children into the workforce. ${ }^{21}$ Women who worked to supplement the low or irregular wages of a husband or fully supported their families went against the grain of the model home and family life. Women, especially mothers, who held jobs beyond their domestic duties of cooking, cleaning, and sewing or provided the primary source of income for a family, threatened the ideal. As Historian Carolyn Strange has written, "By the early twentieth century waged labor for women had become virtually synonymous with city life, and increasingly it entailed work that was conducted beyond the domestic sphere."22 This perceived menace to the ideal society troubled local, state, and national leaders.

\footnotetext{
${ }^{19}$ Linda Gordon, Pitied But Not Entitled: Single Mothers and the History of Welfare, 1890-1935, (New York: The Free Press, 1994), 22.

${ }^{20}$ Lisa M. Fine, The Souls of the Skyscraper: Female Clerical Workers in Chicago, 1870-1930, (Philadelphia: Temple University Press, 1990), 53.

${ }^{21}$ Alice Kessler-Harris, Out to Work: A History of Wage-Earning Women in the United States, (Oxford: Oxford University Press, 1982), 121.

${ }^{22}$ Strange, Toronto's Girl Problem, 22.
} 
Fewer men choosing to marry was one impact of urbanization that contributed to the demographics of Peoria. Many men found family obligations overwhelming during times of economic recessions and unemployment and abandoned family life rather than appear as failures. Gordon notes an increase in desertion in larger cities in the U.S., as urbanization lent itself to anonymity and greater mobility. ${ }^{23}$ Deserters could simply disappear into the city and leave their families behind. Abandoned mothers in the city were left to both earn a living and care for their children often without any familial support. Unmarried women who lived in rural areas could be assimilated into a family member's household and could contribute by doing housework or caring for children, but the urban dynamic worked differently. In urban areas, single, widowed, divorced, or abandoned women had migrated into the city alone thus did not possess family ties that provided a safety net for them or their children. Physical space and the family economy put constraints on what families in the city could do to help each other. Many poor wage-earning women turned to benevolent associations for assistance to make up for this lack of familial support.

Peoria was one of many Midwestern cities grappling with the impact of urbanization. Examining working-women in Davenport, Iowa, historian Sharon Wood has claimed that female employment in cities emerged as a social problem as early as the $1870 \mathrm{~s}^{24}$ The problem developed as women left the domestic sphere and began to compete with men for jobs. The issue expanded as wage-earning women and their dependents experienced extreme poverty due to inadequate pay. Davenport, situated along the Mississippi River, provided markets, services, employment, and entertainment very similar to Peoria and was a magnet for women migrating

${ }^{23}$ Gordon, Pitied But Not Entitled, 20.

${ }^{24}$ Wood, The Freedom of the Streets, 31 
from small towns and rural areas in search of work. ${ }^{25}$ Women worked in a variety of occupations in the service industries as well as light manufacturing work, but most wage-earning women in Davenport found jobs in domestic service. Whether a woman worked in a hotel, department store, clothing factory, or served in a private home the wages she earned were inadequate, making it extremely difficult to make ends meet. Many women in Davenport, like Peoria, turned to occasional or full-time prostitution in order to get by. ${ }^{26}$

Detroit, Michigan, another growing industrial city very similar to Peoria also attracted women with the hope of employment and independence. By the turn of the century, Detroit was one of the largest cities in the United States, offering its residents countless opportunities and enabling all members of a working-class family to contribute to the family economy. Historian Kyle Ciani found that as Detroit grew into an industrial giant, its dependence on female day workers grew as well. ${ }^{27}$ Many young, independent women found work in the service industry by cooking and cleaning for the growing middle-class sector instead of factory work. Many wageearning women in Detroit received poor wages and struggled to make ends meet regardless of their occupation. Like Detroit and Davenport, Peoria offered a variety of employment options for women.

\section{TYPES OF EMPLOYMENT}

Wage-earning women developed hierarchies of desirable occupations that reflected class, ethnic, and racial distinctions. ${ }^{28}$ At the top were professional jobs such as teachers and nurses, which required more training and were positions more easily attained by women from the

\footnotetext{
${ }^{25}$ Wood, The Freedom of the Streets, 9.

${ }^{26}$ Wood, The Freedom of the Streets, 100.

${ }^{27}$ Kyle Ciani, "Hidden Laborers: Female Day Workers in Detroit, 1870-1920," The Journal of the Gilded Age and Progressive Era 4, no. 1 (January 2005): 27.

${ }^{28}$ Kessler-Harris, Out to Work, 128.
} 
middle-class. Semi-professional jobs, next on the hierarchy, such as those found in offices required some training but much less than a teacher or nurse. Department store clerking necessitated some level of skills (the ability to communicate with customers and count money) but did not warrant formal training. The lowest positions in the hierarchy were factory workers, waitresses, and domestic servants as they required the fewest skills. Hierarchies reflected a sense of status and moralizing standards. The lower the rung on the hierarchy, the greater the possibility the worker not remain a "good girl."

Peoria offered educational opportunities to train middle-class girls for those muchcoveted professional jobs. Its school system, whose superintendent had the reputation of a "wideawake, progressive educator" according to a 1912 local study, employed 325 teachers throughout forty-eight public and parochial schools including kindergartens and a normal department for “training young women in scholarship, pedagogical principles and professional attitude." 29 Purportedly, the citizens of Peoria recognized the importance of a high school education in meeting the demands of modern civic life for both male and female students. ${ }^{30}$ Educators and school officials attempted to meet the modern needs of all children throughout the city regardless of class, gender, race, or ethnicity by erecting new school buildings in working-class neighborhoods. Bradley Polytechnic Institute, three business colleges, four music conservatories, and two academies further bolstered educational opportunities within the city and added to the attraction the city held to newcomers, like young women from rural areas in Central Illinois.

The Peoria State Hospital was one of those attractions. It housed a training school for nurses in caring for mentally ill patients and patients with communicable diseases, and prepared

\footnotetext{
${ }^{29}$ Rose Pfeiffer, "Peoria Public Schools" in Peoria City and County Illinois A Record of Settlement, Organization, Progress, and Achievement, Vol I, ed. James M. Rice (Chicago: The S.J. Clarke Publishing Company, 1912), 388389.

${ }^{30}$ Pfeiffer, "Peoria Public Schools," in Peoria City, 189.
} 
nurses for supervisory roles. ${ }^{31}$ Between 1890 and World War I, the number of women seeking professional training soared nationwide. Citing nursing as an example, Kessler-Harris discovered that in a ten-year period from 1900 to 1910 the number of trained nurses increased seven times. ${ }^{32}$ The 1911 White's City Directory bears this out for Peoria, as it listed over eighty female nurses in Peoria. ${ }^{33}$ Women graduating from institutions of higher learning found professional and semiprofessional jobs in Peoria as well as in other parts of the state.

Office work was one of the more desirable lines of work for white, native-born, single, and educated female wage earners. Women often chose clerical work because the hours, wages, and work conditions were more favorable than department store clerking or teaching. ${ }^{34}$ It also was more prestigious for workers and their parents. Women who trained at one of Peoria's business schools acquired the necessary skills to work as stenographers and typists. A woman was considered a competent typist and stenographer after a year of secretarial school, but less training was required for file clerks, telephone operators, and receptionists. ${ }^{35}$ To produce maximum efficiency with minimal training, many office jobs were reduced to trivial tasks resembling factory work.

Most of the wage-earning women in Peoria did not find employment in clerical work but labored in unskilled jobs in factories, department stores, or domestic service. By 1915, Peoria proudly proclaimed itself the "World's Center of Production and Consumption" and "The Central City of the Great Middle West” with "unequaled advantages for manufacturing, opportunities for business enterprises, superior transportation facilities, homes, schools, churches

\footnotetext{
${ }^{31}$ Illinois General Hospital for the Insane at Peoria. Ninth Biennial Report of the Peoria State Hospital at Peoria Illinois July 1, 1910 to September 30, 1912 (Springfield: Illinois State Journal Co., State Printers, 1914 ), 10.

${ }^{32}$ Kessler-Harris, Out to Work, 116.

${ }^{33}$ John A. White, White's Peoria City Directory 1911 Directory of the Citizens, Business Directory, Numerical Street Directory and an Appendix of Useful Information with Map (Peoria: John A White Publishing, 1911).

${ }^{34}$ Fine, The Souls of the Skyscraper, 42 and 44.

${ }^{35}$ Kessler-Harris, Out to Work, 148.
} 
and parks." 36 It earned those accolades because of its access to all of the other Midwestern states via railroad and navigable waterways. According to The Peorian, no other city in the United States the size of Peoria had as many million-dollar manufacturing or producing establishments, and those companies produced over a thousand different articles. ${ }^{37}$ That production made the city attractive to people seeking industrial employment. Although many more opportunities existed for men seeking manufacturing work, female job seekers could find employment in facilities that manufactured everything from cigars, to soap, to sugar, and to textiles. However, while women migrated to Peoria to seek industrial work, the ideal did not always materialize as imagined. Factory work in Peoria and elsewhere was unstable for women as layoffs often occurred during economic downturns and many women did not have other skills they could fall back on to quickly replace lost income. Female factory workers were highly exploited and even dispensable, since domestic workers seeking factory work could easily replace them. ${ }^{38}$

Domestic service was one of the few alternatives to factory work for uneducated or unskilled women. Like their sisters in Toronto, Detroit, and Davenport, Peorians worked in domestic service day labor, as laundresses, and cooks, all of which were low paid jobs. These types of jobs gave impoverished women some means to survive but it did not lead to economic stability. Instead, many women were forced to turn to relief agencies like the Y.W.C.A. for help. The Twelfth Annual Report of the Bureau of Labor Statistics of the Illinois Free Employment Offices from 1910, showed that the demand for domestic servants in Illinois

\footnotetext{
${ }^{36}$ Committee of the Peoria Association of Commerce, The Great Middle West Peoria-The Central City (Peoria: Peoria Association of Commerce, 1912). The states included within the Great Middle West were Ohio, Indiana, Michigan, Illinois, Wisconsin, Minnesota, both North and South Dakota, Nebraska, Iowa, Kansas, Missouri, Oklahoma, Arkansas, Kentucky, and Tennessee.

37 "Peoria From an Industrial Viewpoint - Facts and Figures Taken Principally from the Preliminary Report of Mr. Young Of the United States Census Bureau Report of 1915," The Peorian, V no 1(May 1915): 1. The Peorian further stated, based on data from a United States Census Bureau Report that Peoria employed twelve thousand workers and paid annual wages of eight million dollars.

${ }^{38}$ Strange, Toronto's Girl Problem, 25.
} 
exceeded those seeking employment in that capacity because women found work in factories, stores, and hotels more appealing. ${ }^{39}$ This statement confirmed the research of historian Vanessa May who found that middle-class housekeepers were at a loss as to how to find morally upright and dependable domestic help, and domestics believed these women to be poor employers. May summed up the problem this way: "Domestics, employers complained, were unfit to work in middle-class homes. Middle-class housewives, domestics retorted, were unfit to run them." According to May, domestic service was the largest sector of women's employment into the 1940s and this appeared to be true in Peoria in the first decade of the twentieth century. The Peoria Journal reported in March 1906 that according to the free employment agency, general housework was the most requested employment for girls, and 111 women were placed for employment in a two-week period. ${ }^{41}$

In 1910, 2,357 women, about ten percent of the female population over age fifteen, completed applications for employment at the Peoria Free Employment Office. Over two thousand, or 91 percent, of those applications were for positions in the domestic service industry. ${ }^{42}$ Approximately 90 percent of women seeking domestic work in Peoria through the employment office secured a position; however, this only filled 77 percent of the open

\footnotetext{
${ }^{39}$ David Ross, Twelfth Annual Report of the Bureau of Labor Statistics of the Illinois Free Employment Offices for the Year Ending September 30,1910, (Springfield: Illinois State Journal Co. State Printers, 1911). 1.

${ }^{40}$ May, Unprotected Labor, 2.

41 "Employment Bureau Busy Positions are secured for a large number of applicants," Peoria Journal, March 24, 1906, evening edition.

${ }^{42}$ David M. Katzman, Seven Days a Week: Women and Domestic Service in Industrializing America (Urbana: University of Illinois Press, 1978), 44. Katzman identified the following as domestic service work, general servants, chambermaids, child nurses, cooks, waitresses in families, day workers, laundresses, and other similar works in private households. I included the following in my tabulations; general housework, dayworkers, laundresses, dishwashers, waitresses, chambermaids, cooks, housekeepers, scrubwomen, kitchen help, and pantry work.
} 
positions..$^{43}$ In Peoria, there were more positions available in domestic service than there were workers to fill them.

This coincides with a national trend occurring between 1900 and 1920. The number of female domestic servants grew from 1870 to 1910, declined from 1910 to 1920, and then rose again from 1920 to 1930. David Katzman has attributed this fluctuation to several factors. The rise in urban-based middle-class families who could afford to hire domestic workers created a continuous increase in demand for the service. At the same time, the number of native-born white women entering the domestic service industry declined as new employment opportunities opened up for them in white-collar jobs. Prior to World War I, the influx of immigrants from Europe who were willing to work in household labor helped to supplement the number of nativeborn white women leaving the industry. After the outbreak of the war, the supply of female immigrant workers sharply declined but the demand for their services did not. ${ }^{44}$ Also, many young black girls migrated from the southern states to northern cities lured by the promise of domestic employment, higher wages, and a means to escape the southern caste system. ${ }^{45}$

Peoria experienced these same trends, as is evidenced by several reports of the Peoria Free Employment Offices. In 1906, the superintendent of the Peoria Free Employment Office touched on the demands of domestic labor by middle-class women when reporting on his reasons for changing the opening time of the employment office from 9:00 a.m. to 7:00 a.m. He stated,

I know, from my short experiences, that this business can no more be successfully operated in this city on banking hours, than could a market house or meat shop. Think of

\footnotetext{
${ }^{43}$ Ross, Twelfth Annual Report of the Bureau of Labor Statistics of the Illinois Free Employment Offices There were 453 applications for 830 general housework positions only 52 percent were filled. There were 439 applications for 384 dayworker positions, all which were filled. Dishwasher (186), waitress (170), chambermaid (138), and cook (110) were other top positions applicants women pursued There were 98 open factory positions for only 81 applicants with 89 percent of the positions being filled. Nearly double the amount of women desired clerical work than there were positions available but even so the total seeking this type of work was less than 40 women and the total available positions were less than 20.

${ }^{44}$ Katzman, Seven Days a Week, 46.

${ }^{45}$ Katzman, Seven Days a Week, 208.
} 
a half dozen wives waiting until after nine o'clock on a hot summer morning to call up the Employment Office to have sent to each of them a woman to do their laundry. In almost every instance it would be lunch time before the wash woman could put in an appearance. ${ }^{46}$

The 1916 Free Employment Office report addressed the national crisis "caused by the breaking out of the European War in the fall of 1914. ${ }^{, 47}$ Secretary Luke McCoy explained that the decline in immigrants due to the war had an effect on the supply of labor in Illinois. He claimed the number of immigrants in 1915 was the lowest it had been since 1898 and was one of the reasons for the shortage of labor. Peoria Y.W.C.A secretary, Miss Elizabeth McKenzie, provided further explanation. She noted that many small town and country girls could not sew or cook well nor could they perform basic household tasks efficiently. ${ }^{48}$ The lack of domestic skills made it difficult for these girls migrating to Peoria to find employment in the domestic service industry. In addition, the girls migrating from the small towns were probably young, white, and nativeborn and preferred other lines of work to live-in domestic service.

The abundance of positions available in domestic service did not make it a favorable or lucrative option for workers. By the end of the nineteenth century, most of the domestic workers in the urban north were Irish, German, or Scandinavian immigrants. In Peoria, the majority of foreign-born whites or children of foreign-born whites were likewise born in Germany and Ireland. This concentration of specific ethnicities in domestic service heightened conflict

\footnotetext{
${ }^{46}$ David Ross, Eighth Annual Report of the Bureau of Labor Statistics of the Illinois Free Employment Offices for the Year Ended October 1, 1906, (Springfield: Phillips Bros., Co. State Printers, 1907) 82.

${ }^{47}$ Luke D. McCoy, Eighteenth Annual Report of the Bureau of Labor Statistics of the Illinois Free Employment Offices and the Supervision of Private Employment Agencies for the Year Ending September 30,1916, (Springfield: Illinois State Journal Co. State Printers, 1917), 7.

${ }^{48}$ Edith Gilmore, "Girl Unfitted For City Life Is Never Safe What to Do with Country Lass Is Bring Problem of Y.W.C.A. Miss M'Kenzie Talks New Girls in Some Stores Get only \$4 a Week; Can't Live On It. \$10 Is Safe Minimum," Herold Transcript Monthly, July 1, 1914.
} 
between employees and employers due to employers' ethnic prejudices. ${ }^{49}$ Ethnically charged animosity was not the only source of tension for domestic workers.

Most disagreements between middle-class employers and their domestic servants centered around poor wages, hours on the job, and worker's personal autonomy. ${ }^{50}$ Domestics contended that unlike factory workers who could check out of the factory at a set time every day, their workday never ended. Live-in domestic servants worked six and sometimes seven days a week, began work before their employers even awoke to prepare for the day, and toiled late into the night leaving very little time for rest or leisure. Their employers gave them little independence to complete their work and constantly scrutinized them even during their few moments of free time. Many domestics also complained of the inadequate living quarters provided to them.

A former domestic servant who turned to prostitution provided testimony to the Illinois Senate Vice Committee about her life as a domestic servant. The twenty-eight-year-old woman contrasted living conditions in the brothel to those of a live-in domestic. She contended that in the brothel she had good and nourishing food to eat, sufficient amounts of sleep and rest, a warm room, and bath, and companionship. She complained that domestics in a private home were overworked, underfed, and had no private space. She claimed if she had a visitor, even when she was sick, that the visitor could not use the front door and she had to receive them in the kitchen. She continued:

\footnotetext{
${ }^{49}$ For more on ethnicity and race conflict between domestics and employers see Vanessa May in Unprotested Labor. Percentages were calculated from data presented in the Department of Commerce and Labor and Bureau of the Census, Thirteenth Census of the United States Taken in the Year 1910 Statistics for Illinois. The white population can be segregated as follows: 54.7 percent native white, 20.8 percent native white of a foreign or mixed parentage, and 13.2 percent foreign-born white. The majority of foreign-born whites were born in Germany and Ireland at 42.4 percent and 11.7 percent respectively.

${ }^{50}$ May, Unprotected Labor, 71. See also Priscilla Murolo, The Common Ground of Womanhood, Class, Gender, and Working Girls' Clubs 1884-1928, (Urbana: University of Illinois Press, 1997).
} 
You are worse than any slave that ever was in existence some places. They don't consider you ever get tired or need rest. You are a machine, wound up in the morning, and you work till all hours of the night, in a private family. You are up in the morning before they are up, and you get your meals in a hurry, and do your work all through the day, and then you are expected to work late at night. . . You work all day, and they don't ever stop to figure how many hours you work, and whether you need rest or recreation. They give you a salary of $\$ 5$ a week, and sometimes they give you a salary of $\$ 3$ or $\$ 4$, and think they give you big wages, because you get some dark little room and meals that you are too tired to eat. They simply don't care how many hours you work in domestic service. ${ }^{51}$

Some working-class women preferred the day work model of domestic service for these reasons. Day work included labor such as laundry, cleaning and general housework and working-class families depended on this revenue source. ${ }^{52}$ Women seeking employment in domestic service also preferred day work to live-in positions as it allowed them to return home to their families every night instead of residing in the home of the employer. This was particularly true of black women who viewed the live-in system too close to slavery. Mothers with children at home found day work attractive, since they did not have to give up their children in order to work in the industry. In 1902, only seventy-seven women filed applications for day work. ${ }^{53}$ By 1916, that number had increased to over twelve hundred. ${ }^{54}$ From 1902 to 1916 , more women sought day work positions in Peoria than there were positions available. However, day work carried the same social stigma as other forms of domestic service and was shunned by those who believed they could do better.

A comparison of the demand for two types of labor, domestic service and retail work, shows the demand for domestic labor far exceeded the demand for female retail labor. In 1916, employers listed three thousand and seven hundred open positions for household labor.

\footnotetext{
${ }^{51}$ Report of the Senate Vice Committee, 339.

${ }^{52}$ Ciani, "Hidden Laborers," 24.

${ }^{53}$ David Ross, Fourth Annual Report of the Bureau of Labor Statistics of the Illinois Free Employment Offices for the Year Ending October 1,1902, (Springfield: Phillips Bros., Co. State Printers, 1903), 70.

${ }^{54} \mathrm{McCoy}$, Eighteenth Annual Report, 40. During this same period the population of Peoria only increased by twenty-five percent but the percent of increase in demand for day work was over one thousand percent increase.
} 
According to the testimony of multiple retail employers before the Senate Vice Committee, collectively they could have at most employed five or six hundred female employees.

Secretary McCoy noted that people seeking positions in clerical or retail work did not want to apply at the same employment offices as laborers and domestic workers, which noticeably affected the number of applicants. ${ }^{55}$ It appears from the reports of the Peoria Free Employment Office that the majority of positions available to working-class women fell into the domestic service category, but perhaps there were many women seeking clerical or retail positions in Peoria that did not utilize the services of the Free Employment Office. Employment estimates provided by retail dry good stores to the Illinois Senate Vice Committee suggested that these stores employed hundreds of female employees every year, yet this is not reflected in the Free Employment Office reports. These reports show a small number of retail positions offered through their service, less than thirty. Presumably, like the Larkin Company, these retail stores had their own hiring departments and did not need the service of the employment office.

The entertainment industry in Peoria provided a variety of employment opportunities for women. Peoria was a mecca for the entertainment industry and supported twelve theaters. The Majestic, a "modern" motion picture theater, was on Jefferson Avenue and the Orpheum, a vaudeville theater, was on Madison. Both theaters were an easy stroll or cheap cab ride for working-class women who lived in this hub, which stretched from Monroe Avenue on the west to the Illinois riverfront on the east. Adams Street alone contained six theaters all within a few blocks of each other. ${ }^{56}$ Theaters provided employment for actresses as well as chorus girls, seamstresses, makeup artists, and hair stylists. Wage-earning women not only worked in these spaces; some frequented them during their free time. The entertainment industry attempted to

\footnotetext{
${ }_{55}$ McCoy, Eighteenth Annual Report, 9.

${ }^{56}$ White, White's Peoria City Directory 1911.
} 
woo working-class girls to their establishments by lowering prices and catering to their desires for entertainment. These efforts further increased the anxiety of social reformers who became increasingly troubled over these practices. ${ }^{57}$

Peoria was known as a popular convention city supporting multiple convention halls, department stores, hotels, restaurants, sample rooms, saloons, and theaters to entertain convention goers. In addition to factory work and domestic service, the environment industry provided work for women with little or no skills. ${ }^{58}$ The 1911 White's Peoria City Directory listed eight department stores, forty-eight hotels, twelve theaters, and 322 sample rooms and saloons. ${ }^{59}$ Visitors could find a variety of dining establishments and entertainment venues within walking distance from the train depot, and migrants to Peoria could step off the train and gauge the employment opportunities as they strolled to their lodging.

The alcohol industry in Peoria also opened up employment opportunities for women. Alcohol and the entertainment industry went hand in hand in Peoria. Entertainment seekers could purchase a glass of wine, pint of beer, or shot of whiskey at one of the many tasting rooms or saloons in the entertainment district. People from all sectors of the city easily purchased and consumed spirits in Peoria in part due to the multitude of breweries and distilleries that populated the riverfront. The Great Western distillery, the largest distillery in the world, operated in Peoria alongside other international distilleries including Clark Brothers, Corninge Distilling, and Standard Distilling, earning Peoria the title of "The Whiskey Capital of the World."60 People

\footnotetext{
57 Strange, Toronto's Girl Problem, 117.

${ }^{58}$ The Great Middle West Peoria-The Central City. The Coliseum erected in Peoria in 1901 boasted a capacity of 6,500 and was a testament to the progressiveness of the city leaders.

${ }^{59}$ White, White's Peoria City Directory 1911.

${ }^{60}$ According to Jack Sullivan in his article about The Whiskey Trust published in the September 2009 newsletter Bottle and Extras, the distilling industry was successful in Peoria because of the river and railway access, an bountiful natural water supply, and an abundance of corn and barley. Jack Sullivan, "Peoria's Clarke Brothers \& The Whiskey Trust", Bottles and Extras, September - October 2009, 42. Peoria also had a plentiful coal supply.
} 
from all over the globe came to Peoria to make it big in the distilling industry and their success was a catalyst for many supporting industries. Anheuser-Busch, Pabst, and Schlitz were just three of ten brewing companies operating in Peoria in $1911 .^{61}$

In this era, Peoria produced more spirits than any other city in the United States, an average of 185,000 gallons per day.$^{62}$ Importantly, the vast production of alcohol contributed more alcohol-related taxes to the government than any other distilling center. The revenue from these taxes supported the construction of parks, schools, public works, and magnificent municipal buildings, all which made the city attractive to young women wishing to leave the dull rural areas for the treasures of the city. Holly Karibo has noted that money from the liquor industry had a profound effect on certain communities in Detroit as vice intertwined with the economic and social lives of its residents. ${ }^{63}$ This was certainly true in Peoria as the manufacture, distribution, and consumption of alcohol contributed greatly to its vitality and legendary reputation as a wide-open city. The brewers and distillers not only had a hand in shaping the physical landscape of the city, but also played an active role in politics and helped shape the city's political climate.

The goods and services industries flourished in Peoria as the distilling industry pumped money into the economy. Employment opportunities for men prospered in both blue and whitecollar industries as barrel makers, grain and stock handlers, dockworkers, bottlers, office workers and bankers were all crucial to the success of the alcohol industry. Young women worked in clerical, service, and retail positions connected to the alcohol industry. The Whiskey Barons and bankers who prospered from the industry built impressive homes as well as structures for work

\footnotetext{
${ }^{61}$ White, White's Peoria City Directory 1911.

${ }^{62}$ Reid Mitenbuler, Bourbon Empire: The Past and Future of America's Whiskey, (New York: Viking, 2015), 123.

${ }^{63}$ Holly M. Karibo, Sin City North: Sex, Drugs, and Citizenship in the Detroit-Windsor Borderland (Chapel Hill: University of North Carolina Press, 2015), 34.
} 
and pleasure as office buildings, theaters, hotels, and taverns carpeted the heart of the city and along the riverfront. ${ }^{64}$ Upper- and middle-class families employed female day workers in the homes they built and furnished from the proceeds of the alcohol industry. Joseph B. Greenhut, the biggest distiller in America during the Gilded Age, made his home in Peoria. He entertained members of the Whiskey Trust as well as President William McKinley in his elegant thirty-five room Peoria mansion. ${ }^{65}$

Besides serving in the homes and offices of wealthy distilling executives, women in Peoria found employment on the retail side of the alcohol industry. This line of work, while profitable, proved more difficult for women than men. Men in Peoria's alcohol industry possessed political power and could seek redress for grievances or lobby for change. Female retail sellers were not granted that same privilege and were left no alternative but to operate outside of the law. According to the Peoria Journal many women in Peoria held federal liquor licenses but not city of Peoria liquor licenses. Since women did not have the right to vote in Illinois until 1919 and therefore had no voice in liquor license negotiations, the city refused to issue them liquor licenses. Women such as Margaret Morrow and Anna Daum were fined repeatedly for selling liquor in the city without a license. Thirty-four women were listed in a 1910 news article as holding U.S. liquor licenses but not city licenses, leaving them vulnerable to arrest and hefty fines, whereas their male counterparts, in the same lines of business could hold city licenses and not face those obstacles. Morrow owned a candy kitchen; others listed in the article owned or operated boarding houses or brothels. Male retail liquor sellers, under the 1910

\footnotetext{
${ }^{64}$ Works that examined the whiskey industry include: Dane Huckelbridge, Bourbon A History of the American Spirit (New York: HarperCollins Publishing, 2014); Mitenbuler, Bourbon Empire; and Fred Minnick, Whiskey Women: The Untold Story of How Women Saved Bourbon, Scotch, and Irish Whiskey (Lincoln: University of Nebraska Press, 2013).

${ }^{65}$ Mitenbuler, Bourbon Empire, 123.
} 
ordinance would pay $\$ 600$ annually for a license; Morrow paid a $\$ 50.00$ fine, plus court costs, every time she was arrested for selling liquor, which was often. The Peoria Journal commented on Morrow's situation, “State's Attorney Scholes further announced that he would prosecute her (Morrow) every time he could get the evidence that she has either got to quit the business or take out a city license. She has been fined innumerable times on this charge. The city and county authorities prosecute her frequently and she has paid an immense sum for violations of the law." 66

Women who found it difficult to work outside of the home but needed to earn money could own their own business in Peoria. Taking in boarders was a popular means of bringing in extra income for blue-collar workers ${ }^{67}$ Women also operated home-based businesses as dressmakers, music teachers, and boarding house proprietors. The 1911 White's City Directory listed twenty-nine boarding houses in Peoria, twenty-three of them owned by women. ${ }^{68}$ Women owned a variety of other businesses in Peoria including candy shops, lunchrooms, grocery stores, and saloons. These operations allowed mothers more flexibility in regards to managing their childcare than they would have had working for an employer. These female-owned businesses may have served a dual purpose. Sharon Wood found that many female-owned or operated boarding houses and cigar shops in Davenport actually fronted for brothels. ${ }^{69}$ The Peoria City Directory for 1911 listed 126 women as dressmakers; sixty percent carried the title of "Miss," indicating they were unmarried. Music teacher was also a popular occupation for unmarried girls

\footnotetext{
${ }^{66}$ See "Many Women Holding U.S. Licenses to Sell Intoxicants City and County Authorities, however, Make Prosecutions in Only Two Instances" Peoria Journal, March 10, 1910, morning edition. According to the 1910 Federal Census, Marguerite Morrow owned a confectionery, Anna Daum was a single female who owned and operated a lunchroom, Anna Conkey, Bertha Grant, Alice Greenwood, Georgia Hall, Leona Kahn, Mabel Stellars, Myrtle Mason, Annie Rooney, Ella Williams and Bella Yates all owned or operated boarding houses. Georgia Hall admitted to the Illinois Senate Vice Committee that she operated a brothel.

${ }^{67}$ Kessler-Harris, Out to Work, 124.

${ }^{68}$ White, White's Peoria City Directory 1911.

${ }^{69}$ Wood, The Freedom of the Streets, 22.
} 
and nearly eighty percent of the nurses listed in White's directory were of the "Miss" classification. ${ }^{70}$ The music teachers, nurses, and dressmakers lived on the same streets and even the same blocks as saloons, candy shops and theaters. While there is no definitive evidence to define the character of these women, one can survey the geography of the city to assess the spaces where single women lived.

Much like Davenport, the majority of the female-owned and operated businesses in Peoria were clustered in an area near the riverfront. This probably reflected lower rents that made it more affordable for women to live in the area. ${ }^{71}$ In Peoria, the C.R.I \& P railyard was situated between the river and the businesses along South Water, Washington, and Adams streets where the majority of female-owned business were located. The noise from the railway as well as the many distilleries that lined the riverfront made it a less attractive area for wealthier business owners who could afford property in a better location. The mixed-use district where boarding houses, businesses, and entertainment centers existed side by side was common in many central urban neighborhoods. ${ }^{72}$ These areas allowed wage-earning women to live close, within walking distance, to their respective jobs but also potentially put them in harm's way. Peoria's leaders were concerned that vulnerable working-class women crossed paths with saloon patrons as well as prostitutes as they traversed the streets lined with theaters, saloons, and brothels on their way to work or the local grocery store exposing them to the seduction of the underworld. Living and working in these multi-use districts put working-class girls' morality in jeopardy. The Y.W.C.A was one organization that worked diligently to protect working-girls from the hardships of urban life.

\footnotetext{
${ }^{70}$ White, White's Peoria City Directory 1911.

${ }^{71}$ Wood, The Freedom of the Streets, 26.

${ }^{72}$ Wood, The Freedom of the Streets, 24.
} 


\section{PROBLEMS OF LOW WAGES}

Peoria Y.W.C.A secretary, Miss Elizabeth McKenzie, detailed the obstacles wageearning girls in Peoria faced in 1914 and identified their poor wages as the paramount problem. She claimed that the highest paid jobs for women in Peoria were experienced laundresses who earned around \$7.00 a week, while store clerks earned only $\$ 4.00$ a week. ${ }^{73}$ McKenzie compared these wages to the cost of living in Peoria: "In the first place, rooming places are very scarce in Peoria. It is almost impossible for girls to find places to live. The rooms that we have listed range in price from $\$ 8$ to $\$ 10$ a month. Once in a while we have one at $\$ 6-$ a poor room; that is the lowest." 74 She added that boarding houses that offered board were non-existent in Peoria and calculated that the cheapest that a girl could spend on meals was sixty cents a day, or over $\$ 4.00$ a week. She estimated that laundry would cost a dollar, and carfare would be another seventy cents per week. A working girl in Peoria paying the minimum amount for room, board, laundry and carfare would thus expect to pay around $\$ 7.00$ a week or $\$ 28.00$ per month. This does not take into account the cost of shoes, clothing, or any form of entertainment. According to these estimates, even the highest paid workers would have struggled to live independently.

Wages for female office workers in Peoria varied. In 1913, the Larkin Company, a mail order house for soap and other toilet articles operating in Peoria, employed approximately three hundred girls and women, of which all but eighty-eight worked in the offices. ${ }^{75}$ Larkin paid their new female employees $\$ 5.00$ a week for forty-seven and a half hours of work. The company provided instruction for new employees on various office duties during a training period. Once

\footnotetext{
${ }^{73}$ Edith Gilmore, "Girl Unfitted For City Life Is Never Safe What to Do with Country Lass Is Bring Problem of Y.W.C.A. Miss M'Kenzie Talks New Girls in Some Stores Get only \$4 a Week; Can't Live On It. \$10 Is Safe Minimum,". Ms. McKenzie's estimates were based on her knowledge as secretary of the Peoria Y.W.C.A. but testimony from the employers during the Senate Vice Hearings reported higher wages.

${ }^{74}$ Gilmore, "Girl Unfitted For City Life.

${ }^{75}$ Report of the Senate Vice Committee, 320.
} 
the girls acquired the skills to work on their own, they were promoted out of the training program and paid $\$ 6.00$ a week with the potential to earn over eight. According to Fine, the average weekly wage for all clerical workers in Chicago in the 1890 s was $\$ 8.78 .^{76}$ This is considerably higher than Larkin reportedly paid his workers in Peoria more than ten years later, showing that business owners in Peoria could get away with paying their employees less than their counterparts could in a metropolis like Chicago.

W.E. Persons, a manager at Larkin, claimed to the Senate Vice Committee that the company performed a thorough investigation of prospective employees, which included personal information such as where she lived, how long she had resided in Peoria, and the number of siblings she had: "We have a blank to be filled out. . On this blank they give a sort of personal history of themselves, and state their education, and if they are acquainted with any of the employees. We then get all the information we can from the people they know." 77 Girls and women hired to work in professional and semi-professional jobs were overwhelmingly white and native-born, and Larkin's investigators undoubtedly looked for these qualities in their prospective office workers.

Department stores hired hundreds of female employees and paid a wide range of wages. A 1908 survey showed the average wages of retail store workers in Chicago ranged from \$4.69 up to $\$ 13.33$ a week depending on experience, but Peoria did not match these rates. ${ }^{78}$ In 1913 , Schipper \& Block, the largest retail dry goods store in Peoria, employed approximately 279 girls and women in a variety of positions. The lowest paying positions were waitresses who only worked for two hours a day at the store lunch room, and received a meal and $\$ 3.50$ a week in

\footnotetext{
${ }^{76}$ Fine, The Souls of the Skyscraper, 43.

${ }^{77}$ Report of the Senate Vice Committee, 320.

${ }^{78}$ Meyerowitz, Women Adrift, 37.
} 
compensation. ${ }^{79}$ Errand girls were the next level of workers and earned $\$ 4.00$ a week. ${ }^{80}$ Carl Block, secretary of Schipper \& Block, claimed to the Senate Vice Committee that errand girls lived at home and learned the business at their parents' insistence. ${ }^{81}$

Relief inspectors were a step above errand girls. Their role was to relieve the inspectors or wrappers when they had to be away from their departments. Relief workers worked eight and half or nine hours a day, six days a week and earned $\$ 4.50$ weekly. Wages for other positions in the store ranged from $\$ 5.00$ to $\$ 35.00$ a week. Block estimated that 123 female employees earned less than $\$ 8.00$ week at the Peoria store. As previously noted, girls who worked in offices and department stores needed to dress for their station, which necessitated higher wages. The Schipper \& Block Rule Book dictated their employees' appearance including clothing choice, "Be cleanly and neat in appearance, avoiding extravagance and display. The young women of all Sections, Workrooms, Offices. Etc. will be required to wear black skirts at all seasons of the year, with black or white shirtwaists." ${ }^{" 22}$ This attire would resemble middle-class dress and further signify the preference for white, native-born workers. According to Kessler-Harris, department stores hired more native-born women than any other major woman-employing industry because they were believed to be better educated, have a higher standard of living, and virtuous. ${ }^{83}$

Thomas Greer of Clark \& Company, another retail dry goods store in Peoria, reported similar salaries for similar positions. His store employed approximately one hundred women and girls who performed a variety of duties. He too insisted that the lowest paying positions were

\footnotetext{
${ }^{79}$ Report of the Senate Vice Committee, 296.

${ }^{80}$ Report of the Senate Vice Committee, 297.

${ }^{81}$ Report of the Senate Vice Committee, 296.

${ }^{82}$ Schipper \& Block Rule Book, 7.

${ }^{83}$ Kessler-Harris, Out to Work, 140.
} 
intended for girls who resided with relatives and were not boarders who rented rooms. ${ }^{84}$ P.A. Bergner \& Company employed approximately 124 girls of which only 36 earned more than $\$ 10.00$ a week. P.A. Bergner claimed to have established a precedent in his stores that "a girl who is dependent upon her own resources, entirely, must not be employed at less money than $\$ 40.00$ a month as a minimum. ${ }^{" 85}$ Each retail establishment had an informal apprenticeship where girls could advance in position and pay based on their motivation and ability.

W. J. Roos, manager of the W.D. Putnam Five and Ten Cent Store, claimed his small store functioned as a training ground for girls to get experience and then move onto the bigger stores such as Schipper \& Block or Bergner's. He described the girl's work as mechanical.

The goods are displayed in sight of the customers, and marked. The goods are wrapped, and there is a cash register, and change is made. It is not like the skill that is involved in showing and selling expensive articles, in other stores... We are practically in the position of a school, or an apprentice-shop, for these girls. We make stock-keepers of them, but they are hardly sales-girls, because of the simplicity of their work. Still, when they leave us they possess store experience and can get positions by reason of having worked for us that they could not obtain before. ${ }^{86}$

He used their lack of meaningful skills as an excuse to justify the low wages his store paid to female employees. Roos also claimed that he knew for a fact that all the girls he employed for $\$ 4.00$ a week lived at home because he knew their parents.

Female workers that lived at home with their parents proved a widespread rationale for employers in Peoria to pay them low wages. The Woolworth Five and Ten Cent Store in Peoria employed approximately thirty girls and paid them between $\$ 4.00$ and $\$ 10.00$ a week depending on their experience. The manager, Frank J. Young, estimated that he paid ten of his young female employees $\$ 4.00$ a week and another fifteen between $\$ 4.50$ and $\$ 5.00$ a week. These girls

\footnotetext{
${ }^{84}$ Report of the Senate Vice Committee, 312.

${ }^{85}$ Report of the Senate Vice Committee, 314.

${ }^{86}$ Report of the Senate Vice Committee, 323.
} 
were between the ages of sixteen and eighteen years old, supposedly lived at home, and were not competent "salesladies." ${ }^{87}$ As part of their hiring practice, Woolworth inquired as to the living situation of prospective female employee and tried to only hire those who lived at home unless they were getting more money elsewhere. ${ }^{88}$ Young claimed his store paid older, more experienced “salesladies" between $\$ 7.50$ and $\$ 10.00$ a week, and those who worked at Woolworth for several years could earn Christmas bonuses up to $\$ 25.00$. During the Christmas shopping seasons, the store gave all its employees a 10 percent raise as an acknowledgement of their hard work during the rush season. Woolworth also offered up to two weeks paid vacation for employees who stayed with the company for more than a year.

The Peoria Cordage Company was just one of several factories that employed girls in Peoria. Steuber \& Kuch manufactured tin cans and tin ware and hired approximately 56 married and unmarried women on piecework, girls under the age of sixteen years old, paying them over $\$ 5.50$ a week for an eight hour day. ${ }^{89}$ Henry Kuch, partner in the corporation, claimed girls between the ages of fourteen and sixteen who lived at home and worked an eight-hour day started out at $\$ 4.00$ a week, and girls who worked ten hours a day earned an average of $\$ 8.72$ a week. Meyerowitz argued that the irregular or seasonal nature of factory work exacerbated the problem of inadequate wages.$^{90}$ Piecework did not generally provide a steady or consistent quantity of work so women and girls who completed piecework for Steuber \& Kuch did not earn a guaranteed amount every week, which made it difficult for these workers to budget. While factory work had its drawbacks, young, single, working-class girls preferred factory work to domestic service.

\footnotetext{
${ }^{87}$ Report of the Senate Vice Committee, 284.

${ }^{88}$ Report of the Senate Vice Committee, 284.

${ }^{89}$ Report of the Senate Vice Committee, 343

${ }^{90}$ Meyerowitz, Women Adrift, 36.
} 
Carl Block, secretary of Schipper \& Block, claimed to have conducted his own investigation into the cost of living for girls in Peoria. Block interviewed several girls in his employ who earned from $\$ 7.00$ to $\$ 15.00$ on week. He asserted that he did not interview any girls who made less than $\$ 7.00$ a week because it was his experience that those girls were not dependent on their own wages.$^{91} \mathrm{He}$ found the average cost of room and board among girls in his employ was about $\$ 5.50$ a week or $\$ 22.00$ per month. He estimated it cost an average of $\$ 1.00$ a week for girls to dress and still appear nice enough to work in the store. Laundry was an expense that Block claimed his girls saved money on by doing themselves. He went on to say that, he told girls up front that unless she could earn $\$ 8.00$ a week, then she should not attempt to live on her own. Block's monthly estimates were very close to those of Miss McKenzie's.

Block declared, "It is a very unfortunate circumstance when a girl between sixteen and twenty years old finds it necessary to support herself, without any assistance, without any friends, and it seems to me it is the duty of the community, through some adequate agency, to look after those girls as they do after other dependent classes, morally and physically, for her best welfare, until she is in a position to look after her physical and moral welfare herself, and competent to do so. ${ }^{.92}$ Block realized as an employer that a girl could not go out at night and make money, either legitimately or illegitimately, and still give her best to her day job or retain good health.

Meyerowitz described similar conditions for working-class girls in Chicago. She claimed according to a federal government survey of store and factory workers in Chicago that over half of the women living on their own earned less than $\$ 8.00$ a week.${ }^{93}$ She further contended that

\footnotetext{
${ }^{91}$ Report of the Senate Vice Committee, 297.

${ }^{92}$ Report of the Senate Vice Committee, 298.

${ }^{93}$ Meyerowitz, Women Adrift, 34.
} 
social investigators found that a woman needed a minimum of $\$ 8.00$ to $\$ 12.00$ a week to support herself. At \$8.00 a week, most women lived in poverty and sacrificed meals, warm clothing, and security to scrape by.

Peoria offered wage-earning women a variety of employment options that crossed all employment sectors, allowing women the opportunity to pursue careers in teaching, nursing, business, retail, domestic service or self-employment. Wages for the majority of these positions while consistent with those earned by working women all across the country were inadequate and did not provide a living wage. Women's meager wages compounded other social problems in Peoria's working-class communities as many wage-earning women also grappled with desertion, divorce, illegitimacy, access to state support for single mothers, alcohol abuse, and domestic violence. 


\section{CHAPTER III: CHALLENGES OF WAGE-EARNING WOMEN}

In the summer of 1909, Police Matron Mayall investigated the home of an impoverished East Peoria family where she found the mother, her three children, and a male boarder living in filth. The children were covered in dirt and mosquito bites. The husband and father of the children, a man named Bert Woolen, had been arrested for abandoning his family several years prior, and according to Mrs. Woolen, she had not seen him in years. The Peoria Journal stated he was a known vagrant and had never contributed to the support of his children. Neighbors reported that the boarder living in the Woolen home had been Mrs. Woolen's boyfriend for some time and the two of them had previously worked together at a "resort" in another town. Woolen begged Mayall to let her keep her children and promised to reform. At the conclusion of the investigation, Mayall agreed to allow Woolen to keep her children, providing her conduct was good and she secured a job. Woolen agreed to dismiss her boyfriend from her home and quickly obtained a job as a laundress. ${ }^{94}$

In dealing with single, working-class mothers, such as Mrs. Woolen, progressive-minded social workers attempted to address four main problems: desertion, illegitimacy, access to state support for mothers without an adult male income known as "mothers' pensions," and women's employment. Evidence in Peoria shows divorce, alcohol abuse, and domestic violence posed additional problems. In addressing these problems social workers aimed to censor immorality, to protect children, and to encourage the construction of what they understood to be a proper family: a husband who fully provided for his family, a mother who remained at home to care for

\footnotetext{
94 "Buried Babe Beside Hog Terrible Story of Depravity Family Live in Filth Husband Ditches Wife, Who Has Taken Up With an Affinity," Peoria Journal, August 17, 1909, evening edition. According to the Peoria Journal Woolen had once lived in a boarding house on Hamilton Street. While serving time in the workhouse for wife and child abandonment, his wife filed charges of bigamy, stating he had married another woman without obtaining a divorce from his first wife. She dropped the charges of bigamy against her husband if he promised to support her and her small children, who at the time would all have been under the age of five.
} 
the children, and children who attended school rather than a workplace. ${ }^{95}$ Woolen's husband deserted his family at least four years prior to Mayall's investigation, but a doctor's report showed that Woolen had given birth to a stillborn child just a few years earlier. Woolen's late pregnancy confirmed social workers' fears that women who were deserted and could not remarry were still sexually active and often times this promiscuity resulted in illegitimate children. Yet, they did not always recognize that many single-mothers like Woolen were in hopeless situations. Woolen needed to earn money in order to provide for her children but they were too young to be left alone, which limited her employment options. Taking in boarders allowed a mother like Woolen to care for her children and earn a little money. Social agencies, however, discouraged this option for single mothers because of the immoral possibilities that they might engage in sexual relationships with boarders. ${ }^{96}$ The need to earn a living wage to support children and the barriers that inhibited this created mental and emotional burdens for single mothers. Woolen may have used whiskey to help her cope with the stresses of single parenthood. The newspaper account reported she was drunk during the interview with Matron Mayall and had admitted to drinking whiskey, but she also insisted that she did not make a habit of it. ${ }^{97}$

This chapter describes women like Woolen in Peoria, who dealt with social problems that reformers identified: desertion, divorce, domestic violence, alcohol abuse, illegitimacy, and access to mothers' pensions, a state subsidy for families with dependent children who lacked adult male income. Middle-class standards developed in the late nineteenth century persisted into the twentieth century and shaped the perceptions and judgements of social workers, judges,

\footnotetext{
${ }^{95}$ Linda Gordon, Heroes of Their Own Lives: The Politics and History of Family Violence Boston: $1880-1960$ (New York: Penguin Books, 1988), 99. See also Sherri Broder, Unfit Mothers, and Neglected Children Negotiating the Family in Late Nineteenth-Century Philadelphia (Urbana: University of Chicago Press, 1997) and Wini Breines and Linda Gordon, ““"The New Scholarship on Family Violence.” Signs 8, no. 3 (Spring 1983): 490-531.

${ }^{96}$ Gordon, Heroes of Their Own Lives, 97.

97 "Buried Babe Beside Hog Terrible Story of Depravity Family Live in Filth Husband Ditches Wife, Who Has Taken Up With an Affinity," Peoria Journal, August 17, 1909, evening edition.
} 
and other reform-minded Peorians. Many women who were deserted or divorced were compelled to find a way to support themselves and their children. The realities of their lives clashed with the enduring middle-class maternalistic principles that favored separate spheres ideology. Women's employment is integral to the analysis of each problem as many of these social problems forced women to become independent providers, and in this chapter, I assess how wage-earning women navigated life in Peoria when faced with these many challenges.

Incidences of non-support, desertion, and divorce are important to the study of workingclass women because these events created instability in the home and forced women into the urban workforce. Single mothers competed with young wage-earning girls for jobs in Peoria and both suffered due to the inability to earn a living wage. Domestic violence and alcohol abuse often contributed to incidences of non-support, desertion, and divorce, and young women in Peoria were often vulnerable to assaults from men in their homes or on the city streets. Furthermore, the female children of deserted or divorced parents became wage-earning girls as they left the family home for work at an early age to help support their single-parent households.

\section{DESERTION}

By the twentieth century, reformers understood the problems facing families whose fathers did not provide economic support. A study in 1913 revealed that twenty percent of the children committed to New York City orphanages were children of deserting fathers. ${ }^{98}$ Desertion contributed to the growing number of wage-earning women who grappled with surviving in the city and contributed to a growing national concern for women who were married to "nonsupporters." Many women abruptly found themselves in a desperate situation when the primary provider of the home left them. Torn between the need to support their children and the

\footnotetext{
${ }^{98}$ Monroe M. Goldstein, Family Desertion and Non-Support: Report of the National Desertion Bureau Incorporated for Three Years 1912-1915 (New York: National Desertion Bureau, Inc., 1915), 3.
} 
traditional gender roles that placed them in the home, many single mothers were suddenly compelled to find employment and support their families. ${ }^{99}$

Desertion was known as the "poor man's vacation” and was widespread among immigrants and in slum districts in bigger cities. ${ }^{100}$ Monroe M. Goldstein, Secretary and Counsel for the National Desertion Bureau, claimed in 1915, "Family desertion is not a simple crime, but is inextricably woven with social and economic factors." ${ }^{101}$ Goldstein defined desertion as the willful and voluntary separation of a husband/father from his wife and children, without justification or intention of returning to them. He categorized the deserters into two types: nonsupporters (a man that lived at home but did not support the family economically) and abandoners, (a man who moved out of the home, left no clue regarding his destination, and refused to pay maintenance to his family). Goldstein concluded that the National Desertion Bureau was socially necessary. Not only did desertion pose an economic crisis for social agencies who provided aid to deserted families but it also posed a moral issue for middle-class social workers. Women who were married to deserters could not legally re-marry men who would support them and their children. This ultimately led to couples living together, claiming to be married, and perhaps producing illegitimate children. ${ }^{102}$ This presented a threat to the ideal family situation and contributed to the instability of the home.

Family desertion situations occasionally led women into prostitution as a way to support themselves or family members. Sometimes an abandoned mother resorted to prostitution to support herself and other times a daughter turned to prostitution to contribute to the family

\footnotetext{
${ }^{99}$ Elaine Frantz Parsons, Manhood Lost: Fallen Drunkards and Redeeming Women in the Nineteenth-Century United States (Baltimore: The John Hopkins University Press, 2003), 161.

${ }^{100}$ Alfred Cahen, Statistical Analysis of American Divorce (New York: Columbia University Press, 1932 ), 16.

${ }^{101}$ Goldstein, Family Desertion and Non-Support, 6.

${ }^{102}$ Gordon, Heroes of Their Own Lives, 90.
} 
income. Prostitution was a major concern for Progressive-era social workers and was tied to many of the domestic problems they attempted to address.

The story of a twenty-six year-old Peoria prostitute illustrates the relationship between non-support, poverty, and prostitution. The woman began working in Peoria when she was fourteen to help support her family. ${ }^{103}$ She earned three dollars a week at a laundry and even though she gave all of her earnings to her mother, she felt they did not have enough to eat or buy clothing. She claimed her mother suffered because her father, like most men she knew, drank a lot. ${ }^{104}$ Historian Robert Griswold has explained how reformers believed that alcohol destroyed the work ethic leading to a downfall of a male breadwinner who could not hold a steady job and support his family. ${ }^{105}$ After falling into prostitution, the young woman continued to give her mother most of her earnings, which ranged from fifty to one hundred dollars a week, and kept only enough to buy her own clothing. Her experience was typical of working-class families as older children often worked to help supplement the primary breadwinners' income. Child labor was important to the family economy especially in families where the father was "shiftless," could not keep steady employment, or in single-parent families. Linda Gordon has estimated the rate of employment for children of single mothers was two to three times higher than for two parent families. ${ }^{106}$ It is not surprising that young girls turned to prostitution since they could earn twenty times more money prostituting than they could earn performing "honest" work. The prostitutes fall into vice was the direct result of the poverty her family experienced due to her father's non-support.

\footnotetext{
${ }^{103}$ Report of the Senate Vice Committee, 332. Clarks was on Jefferson and Main Streets near the vice district. ${ }^{104}$ Gordon, Heroes of Their Own Lives, 91. Cyclical, structured unemployment created feelings of inadequacy or failure for many working-class men like the prostitute's father, which often led to depression and alcohol abuse. ${ }^{105}$ Robert Griswold, "Divorce and the Legal Redefinition of Victorian Manhood," in Meanings for Manhood: Construction of Masculinity in Victorian America, ed. Mark C. Carnes and Clyde Griffen (Chicago: University of Chicago Press, 1990), 103.

${ }^{106}$ Gordon, Pitied But Not Entitled, 24.
} 
The Woolen family also illustrates the effects of desertion. Matron Mayall was called to the Woolen home to investigate the neglect of the children, and her reaction to this mother and her handling of the situation was typical of progressive reformers during the early twentieth century. During the Progressive Era, as Linda Gordon has explained, "Single motherhood and child neglect were mutually and simultaneously constructed as social problems, and many of the defining indices of child neglect, such as lack of supervision, were essential to the survival of female-headed households." ${ }^{107}$ Middle-class reformers found it hard to distinguish neglect from poverty. While many poor parents did the best they could for their children with limited resources, social workers saw manifestations of child neglect. However, Gordon emphasizes that “dirty clothing, soiled linen, lice and worms, crowded sleeping conditions, lack of attention and supervision, untreated infections and running sores, rickets and other malformations, truancy, malnutrition, (and) overwork" were direct results of poverty. ${ }^{108}$

Working women, with and without dependents, found it difficult to live independently in the city. Single working mothers confronted the additional burden of caring for the health and well-being of their children. Day nurseries were scarce during this period and small children could not be left unattended while mothers worked outside of the home, which further limited their employment options. In Peoria and elsewhere, single mothers were less likely than other parents to ask for placing out of their children so that they could work. ${ }^{109}$ As is demonstrated by Woolen's plea to the police matron, most single mothers wanted to keep their children with them despite the hardship that it created. Accordingly, many working mothers relied on the services provided by charitable organizations to help care for their children.

\footnotetext{
${ }^{107}$ Gordon, Heroes of Their Own Lives, 84.

${ }^{108}$ Gordon, Heroes of Their Own Lives, 95.

${ }^{109}$ Gordon, Heroes of Their Own Lives, 106. Placing out is a system of caring for dependent children by placing them in private families instead of putting them in an orphanage
} 
It is thus possible that the Woolen children were unclean and unkempt simply because their abandoned mother did not earn a living wage and not because she was neglectful. Woolen's marital situation automatically devalued her in the eyes of the middle-classes because her home life did not conform to the norms of domesticity, femininity, and mothering. ${ }^{110}$

Social workers assessed domestic situations differently when a single mother headed the home. The deserted or widowed single mother earned some sympathy from social workers whereas divorced or unmarried mothers largely earned condemnation. A single mother whose morality was in question received more judgement and less help than did a married mother in need. This is evident in the number of women who received a mothers' pension, state subsidies for families with dependent children who lacked adult male income, as more widows and deserted mothers received assistance than unmarried mothers did. Social workers were quick to blame neglect on unwed mothers who they characterized as "incompetent, insensitive, and untrained." 111

\section{DIVORCE}

Divorce also contributed to instability and poverty in the working-class home and often forced young women into the workforce to help support their families. Working-class couples repeatedly reported infidelity, abandonment, abuse, and drunkenness as reasons for divorce petitions. The ill effects of pregnancy, especially due to illegal abortion, also plagued women. Many reformers attributed these social problems to the effects of urbanization and rising industry. Dr. Alfred Cahen, for example, concluded in his 1928 study of American divorce that urbanization appeared to be distinctly associated with divorce: "Urbanization is synonymous with growing economic production and the accelerated speed of living in industrial cities, such

\footnotetext{
${ }^{110}$ Gordon, Heroes of Their Own Lives, 84.

${ }^{111}$ Gordon, Heroes of Their Own Lives, 61.
} 
circumstances tending to cause increased friction in family circles. City life involves a complexity of interacting factors affecting the unit of the home." 112 While the causes of divorce were undoubtedly more complex, the urban environment certainly contributed to unfavorable conditions in the home that led to infidelity, abandonment, abuse, and drunkenness.

The story of another young Peoria prostitute illustrates the deleterious effects of divorce on working-class families. The twenty-eight-year-old woman claimed her parents divorced when she was eleven years old and her father never provided for his family. ${ }^{113}$ She maintained that he was a drinking man and would not stick to a job. Her mother worked hard to support seven children, each of whom had to work as well. The young woman started working at age thirteen in private homes taking care of children and doing house work during the summer. When she was old enough to leave school she worked in a laundry, then a grocery store, and then in the office of a laundry business before finally falling into prostitution. The girl's devolution into prostitution after a series of more reputable jobs was a common story among prostitutes and resulted in the inability to earn a living wage through legitimate means.

Life was particularly hard for divorced women, since divorce carried a social stigma and hefty financial costs. Filing for divorce was costly, time consuming, and uncomfortable, as the petitioner had to hire and pay an attorney, give testimony, answer questions about personal issues, produce witnesses, and serve divorce papers to a spouse. The process could cost close to a month's wages for some women. ${ }^{114}$ Unwillingness to recount a husband's cruelty publically due to fear or shame could keep a battered wife from obtaining a divorce. Moreover, middle-class reformers viewed divorce as an assault on the ideal family life.

\footnotetext{
112 Cahen, Statistical Analysis of American Divorce, 62.

${ }^{113}$ Report of the Senate Vice Committee, 338.

${ }^{114}$ David Peterson, "Wife Beating: An American Tradition," The Journal of Interdisciplinary History 23, no 1 (Summer 1992): 102.
} 
The federal Bureau of the Census collected statistics on marriage and divorce in the United States from 1867 to 1906 and again in 1916. The findings of the first twenty-year period from 1867 to 1906 , published in 1909 , revealed that nationally the normal rate of increase for divorce in a 5-year period was about thirty percent, and the rate of increase of divorce was far greater than the rate of increase in population. ${ }^{115}$ Both reports showed that divorces obtained by the wife were twice a numerous as those obtained by the husband. Investigators attributed this to the reasons given in the divorce petitions: a wife could more easily claim non-support, neglect, or cruelty. ${ }^{116}$ The 1909 report found that white women in northern states filed for divorce more often than white women in the South for two reasons: first, northern white women had more employment opportunities, and second, they were more accustomed to the idea of earning their own living. ${ }^{117}$ Women in Peoria had opportunities for employment, but few of these paid a living wage, therefore the threat of poverty was a real consequence for many women contemplating divorce. In both the 1909 and 1916 reports, desertion proved the principle cause of divorce with cruelty named as the second. ${ }^{118}$ This was true in Illinois, where close to 50 percent of divorces were caused by desertion. ${ }^{119}$ Drunkenness or intemperance accounted for a very low percent of reasons given for divorce, but when employed as a contributing factor to neglect or cruelty, intemperance was present in one out of every five divorce cases. Intemperance was cited as an indirect cause in one out of every three cruelty cases and one out of every five neglect cases in

\footnotetext{
${ }^{115}$ Bureau of the Census Special Reports: Marriage and Divorce 1867-1906 Part I Summary, Laws, and Foreign Statistics (Washington D.C.: Government Printing Office, 1909), 12.

${ }^{116}$ Marriage and Divorce 1867-1906, 25 listed the following as falling under the classification of cruelty: cruelty, extreme cruelty, repeated cruelty, intolerable cruelty, intolerable severity, cruel and abusive treatment, cruel and inhuman treatment, cruel and barbarous treatment, attempt to take life, indignities rendering life intolerable, excesses and outrages, treatment endangering reason, treatment injuring health, violence endangering life.

${ }^{117}$ Marriage and Divorce 1867-1906, 25.

${ }_{118}$ Bureau of the Census, Marriage and Divorce 1916, (Washington D.C.: Government Printing Office, 1919), 15. ${ }^{119}$ Analysis of statistics for years 1902 to 1906 and 1916 complied from Marriage and Divorce 1867-1906 Part II pages 17-19 and Marriage and Divorce 1916, 24.
} 
which the wife secured divorce. ${ }^{120}$ Wives brought divorce suits against their husbands who did not conform to the new middle-class ideal of manhood and demonstrated drunken, domineering, cruel, or abusive behavior.

Infidelity was also a common justification cited in divorce cases for both men and women. The middle-class ideal for manhood included male sexual fidelity and self-control but similar rules extended to wives who were to be pure, passionless, and morally superior to their husbands. ${ }^{121}$ Nationally, adultery was the second most cited reason for divorces granted to husbands in the late nineteenth and early twentieth centuries. ${ }^{122}$ In Illinois, desertion caused over fifty percent of divorces annually from 1902 to 1906 and almost sixty-five percent of divorces in 1916. Adultery was the second leading cause in Illinois ranging from twenty-five to thirty percent of all cases brought by men. ${ }^{123}$ For a wife to be labeled adulterous was a serious allegation, and court officials realized the accusation alone could ruin a woman's life, which gave husbands immense power. Many courts took steps to protect women against unfounded charges of adultery by limiting the evidence that could be used to sustain allegations and by declaring that false accusations constituted extreme cruelty. ${ }^{124}$ Records in Peoria indicate several cases of men who filed for divorce due to adultery. For example, Frank Larson, a carpenter, filed for divorce in 1910 from his wife Anna charging that she was living in a state of open adultery with another man. ${ }^{125}$ Wintford Harper accused his wife Emma of adultery and filed for just two years into their marriage.

\footnotetext{
${ }^{120}$ Marriage and Divorce 1867-1906, 29.

${ }^{121}$ Griswold, Meanings for Manhood, 105.

${ }^{122}$ Marriage and Divorce 1867-1906, 25.

${ }^{123}$ Analysis of statistics for years 1902 to 1906 and 1916 complied from Marriage and Divorce 1867-1906 Part II pages 17-19 and Marriage and Divorce 1916, 24.

${ }^{124}$ Griswold, Meanings for Manhood, 106 and 108.

${ }^{125}$ Frank W. Larson is listed consistently in the Peoria city directory as a carpenter living on New York Avenue.
} 
In Illinois, adultery was the fourth most cited reason for divorce petitions filed by women. ${ }^{126}$ While men certainly committed adultery, wives found it easier to file for divorce due to "cruelty" unless it was blatantly easy to prove. Such was the case for Pearl Parr who filed for divorce from her husband Fred Parr, a barber at the Hotel Lud shop, after he lived for an entire summer with another woman, Pearl Bennett. ${ }^{127}$ Mr. Parr claimed that Ms. Bennett had gotten pregnant by another man and he had taken compassion on her and allowed her to live with him while she was ill. Parr and Bennett were indicted for living in an open state of adultery, charges that were published in the city newspaper. ${ }^{128}$ Even if the accused adulteress was found innocent or the divorce was not granted, the reputation of the accused woman was destroyed.

\section{MOTHERS' PENSIONS}

Social workers were concerned about access to mothers' pensions as the care of dependent families was the center of their work. Into the twentieth century, some single mothers could receive some aid from social organizations and later a mothers' pension but eligibility could be an issue for many women who needed the additional support. Illinois passed the first publically funded aid for mother-only families in 1911. Reformers intended the mothers' pension to provide subsidies to families without an adult male provider as long as the mother accepted middle-class behavioral norms. ${ }^{129}$ The Funds to Parents bill authorized courts to disburse public funds to poor parents to help properly care for impoverished children. ${ }^{130}$ Juvenile court judges hesitated to remove children from their unsupported mothers simply because they were poor and

\footnotetext{
${ }^{126}$ Analysis of statistics for years 1902 to 1906 and 1916 complied from Marriage and Divorce 1867-1906 Part II pages 17-19 and Marriage and Divorce 1916 page 24. Desertion, cruelty, and habitual drunkenness were first, second, and third respectively.

127 "Sues The Gay Barber For Severance Of Ties," Peoria Journal, March 4, 1910, evening edition.

128 "Good Samaritan Will Be Parr's Defense," Peoria Journal, February 10, 1910, evening edition.

${ }^{129}$ Mark H. Leff, “Consensus for Reform: The Mothers'-Pension Movement in the Progressive Era," Social Service Review 47, no. 3 (September 1973): 397.

${ }^{130}$ Goodwin, Gender and the Politics of Welfare Reform, 104.
} 
believed that many children became delinquent because their working mothers could not care for them. The pension helped keep children with their mothers and kept children from becoming wage earners at a young age. The bill reflected the social value of keeping a family together, the responsibility of the community to help care for poverty-stricken children, and the growing anxiety over the problem of dependent motherhood. ${ }^{131}$

Mothers' pensions were meant to supplement a family's income and help raise a family's standard of living. Applicants for mothers' pensions could be denied for a variety of reasons, including if the examiner believed the mother could be self-supporting, if the mother refused to disclose fully her economic situation, or if the mother's moral behavior was questionable. ${ }^{132}$ Racial and ethnic identity also played a major role as the only mothers approved for a pension were those considered white. When children in the household reached a certain age, they were expected to contribute to the family income. Very few of the women who received a pension could earn money by working out of the home by taking in washing, sewing, or boarders. Women who wanted to earn money by keeping boarders could not take in male boarders who were not family members. The fear of immoral sexual relationships with boarders was a real concern for social workers. Women who needed to find work outside of the home but had children to care for faced more of a challenge because day nurseries were rare. Those that did exist were privately operated and were selective in the children that they cared for. The day nursery movement was an upper- and middle-class response to the growing number of wageearning mothers during the Progressive era. Reformers attempted to apply their values of the

\footnotetext{
${ }^{131}$ Goodwin, Gender and the Politics of Welfare Reform, 22.

${ }^{132}$ Goodwin, Gender and the Politics of Welfare Reform, 167.
} 
home to the public sphere by creating public institutions to care for children while their mothers worked outside of the home. ${ }^{133}$

\section{DOMESTIC VIOLENCE}

Peoria had a higher number of divorces between 1902 and 1906 compared to other cities in Illinois with a population over 25,000. ${ }^{134}$ This is consistent with the national trend, which saw a record jump in divorces to wives on the ground of cruelty during the same time. ${ }^{135}$ Historian Robert Griswold has explained that changes in sex roles and family life at the turn of the century prompted couples to demand more of their marriages. When expectations did not meet reality, many couples turned to divorce. ${ }^{136}$ Women filed a record number of divorce petitions in the Peoria Circuit Court in the summer of 1909, and many listed domestic and alcohol abuse as their reasons. This is consistent with the national findings that alcohol was often a contributing factor to abuse in divorce petitions. Peoria lawyer Abraham Jacobson filed the seventy-fourth divorce petition of the year on behalf of his client, Mrs. George Jacobs. The Peoria Journal reported that it was the fourth suit filed for the day and the twelfth filed by Jacobson during the term. Jacobson bragged to the reporter that his "general average in making two homes where there was previously but one" was much higher than the law firm of Dailey \& Miller, his closest competitor. ${ }^{137}$ Mrs. Jacobs had only been married for four years when she alleged extreme and

\footnotetext{
${ }^{133}$ Anne Durst, "Of Women, by Women, and for Women: The Day Nursery Movement in the Progressive-Era United States," Journal of Social History 39, no. 1 (Autumn, 2005), 142. See also Sonya Michel, Children's Interests/Mothers' Rights: The Shaping of America's Child Care Policy (New Haven, 1999) and Elizabeth Rose, A Mothers' Job: The History of Day Care 1890-1960 (New York, 1999).

${ }^{134}$ Marriage and Divorce 1867-1906, 714-715. Peoria County reported 800 divorces in total from 1906 to 1902, averaging 160 divorces per year with a peak in 1905 of 203 divorces. Sangamon county was the second highest with an average of 147 divorces per year.

135 Robert L. Griswold, "Law, Sex, Cruelty, and Divorce in Victorian America, 1840-1900," American Quarterly 38, no. 5 (Winter 1986): 722.

${ }^{136}$ Griswold, "Law, Sex, Cruelty, and Divorce in Victorian America, 1840-1900," 722.

137 “Seventy-four Suits For Divorce On Five Days Yet Before Entries for the September Term Close," Peoria Journal, August 29, 1909, evening edition.
} 
repeated cruelty by her husband as the grounds for divorce. Just a few days prior, a Peoria

Journal reporter commented on the causes for the record number of divorce petitions and speculated if it was due to the summer heat or if it had become fashionable to divorce. ${ }^{138}$

Mrs. Cora Muegele asserted in her divorce petition that her husband Godfrey was a good husband until he started drinking and began to beat her. Godfrey operated a saloon on Hecox Street in Peoria from 1907 to $1909 .{ }^{139}$ Mattie Prince filed for divorce in 1909 alleging that her husband George liked to drink too much and then beat her. ${ }^{140} \mathrm{Mr}$. Prince was a paving contractor and Mattie Prince kept a boarding house on North Jefferson Street. ${ }^{141}$ Wife beating was often blamed on drinking but not all cases of domestic violence stemmed from alcohol consumption. Social relations involved in drinking escalated hostilities between husbands and wives. Husbands and wives argued over the amount of money spent on alcohol as well as who was drinking and where. Wives accused husbands of depriving the family of necessities when they spent their pay on beer instead of handing it over for food or provisions for the family. Men often drank in saloons away from their wives, and saloon camaraderie tended to escalate or encourage marital disputes.

Florence Miller, age fifteen, filed for divorce from her nineteen-year-old husband, Albert, on the grounds of extreme and repeated cruelty, which began shortly after their wedding just a few months before. The Millers were married in February 1909 in secret and because of Florence

\footnotetext{
138 “Divorce Will Break Record More Cases Filed For Sept. Than Ever Are Coming In Swarms," Peoria Journal, August 21, 1909, evening edition.

139 John White, White's Peoria City Directory 1907 Directory of the Citizens (Peoria: J.W. Franks \& Sons, 1907).

140 "Sixty Divorce Suits Filed Two Weeks Yet Before Last Day of Service Are Coming in Rapidly Mesdames Muegele and Prince Say Husbands Like Whiskey Too Well," Peoria Journal, August 18, 1909.

${ }^{141}$ Thirteenth Census of the United States, 1910, (National Archives and Records Administration microfilm publication T624_316; page 10B; Enumeration District: 0078; FHL microfilm: 1374329)

https://search.ancestry.com/cgibin/sse.dll? indiv=1\&dbid=7884\&h=5799107\&tid=\&pid=\&usePUB=true\&_phsrc=cDo470\&_phstart=successSourc $\underline{\mathrm{e}}$
} 
Miller's tender age, they lied to court officials in order to obtain a marriage license. The Peoria Journal claimed, "Immediately after the marriage, Miller began a course of treatment the like of which no woman in Peoria had ever to bear so soon after her marriage." ${ }^{142}$ Albert Miller was sent to the Workhouse in July for assaulting his young wife in public, and if it had not been for the interference of others, he would have killed her. ${ }^{143}$ Most police tried to maintain order by simply urging dangerous or drunken characters to behave. Offenders were arrested, paid a fine, and then were released shortly after. A few men like Albert Miller served some time but most did not. ${ }^{144}$

Rose Doolin was not as lucky as Miller. Her husband, William Doolin, attacked her in a drunken rage, kicking and beating her so severely that death was almost certain. The Doolins lived in rooms above a candy store, which the Peoria Journal described as being "conducted" by Margaret Morrow on South Adams, an establishment that was often fined for selling liquor without a city liquor license. ${ }^{145}$ Neighbors reported that the couple had been fighting for days and Mrs. Doolin had recently attempted suicide. ${ }^{146}$ The Peoria Journal reported that Mr. Doolin was a well-known character in the neighborhood. As Gordon has argued, marital violence served to enforce female subordination and assert male dominance, which made wife beating a social rather than a personal problem. ${ }^{147}$ Husbands were not the only consumers of alcohol and disputes over wives' social drinking sometimes ended in violence.

\footnotetext{
142 "Child Wife Asks Divorce Mrs. Florence Miller Charges Cruelty Hubby in the Works Mrs. Maggie Donnelly Seeks Separation on Grounds of Bigamy," Peoria Journal, August 28, 1909, evening edition.

143 "Took shot at Wife's Guest Bullet Hits Chicago Drummer in Neck End of Beer Party Wm. Houston Fought When H.L. Saunders Stroked and Kissed His Wife," Peoria Journal, August 25, 1909, evening edition.

${ }^{144}$ Elizabeth H. Pleck, Domestic Tyranny: The Making of American Social Policy against Family Violence From Colonial Times to the Present (New York: Oxford University Press, 1987), 85.

145 "Woman May Die From Beating Rose Doolin Assaulted By Her Husband Condition Is Serious Bail Refused Pending Outcome Of The Kicking She Received," Peoria Journal, August 9, 1909, evening edition

146 "Woman May Die From Beating Rose Doolin Assaulted By Her Husband Condition Is Serious Bail Refused Pending Outcome Of The Kicking She Received."

${ }^{147}$ Gordon, Heroes of Their Own Lives, 251.
} 
Friends and neighbors of Rose Doolin and Mrs. Houston witnessed the violence inflicted on the women by their husbands and attempted to intervene. Men were encouraged to control their passions and this included control of anger and physical violence. Nineteenth century middle-class culture called for the end of traditional male behaviors such as authoritarian control, drinking, gambling, absence from the home, and occasional sexual dalliances. ${ }^{148}$ The fact that Doolin and Houston had some neighborly support during and after the attacks illustrates the proliferation of this ideal. Newspaper citations of divorce petitions provided a public forum for a discussion of appropriate family behavior thus allowing the public to clarify expectations and norms. Wife beating showed a loss of control and therefore was looked down upon, even by the working-class.

Women feared retaliation from abusive husbands for standing up for themselves. Glen Schoonover beat his wife May after she filed for divorce. ${ }^{149}$ Before their marriage, Mr. Schoonover, a bartender, had dated multiple women simultaneously and finally married his wife in August 1908. One year later, he decided he had made a mistake and attempted to make amends with the other woman leading Mrs. Schoonover to file for divorce. The case was heard and dismissed twice. Illinois divorce laws required that the cause of divorce be fully proven by reliable witnesses before a judge would grant the divorce. ${ }^{150}$ It might have been difficult for May Schoonover to produce witnesses to corroborate her story or provide evidence to the judge that a divorce was necessary for her safety. This illustrates another difficulty that women faced when attempting to leave an abusive relationship. May brought suit again in February 1910 claiming

\footnotetext{
148 Griswold, Meanings for Manhood, 97.

${ }^{149}$ A Glen Schoonover appears in the Peoria City Directory in 1907 as working for the Peoria Livery Company, in 1908 as a bartender for C.A. Foote and occupied rooms at 325 Harrison Street, and lastly in 1909 working at J.A. Engel \& Co with his residence as 315 Harrison Street.

${ }^{150}$ Marriage and Divorce 1867-1906, 290.
} 
"Glen had made a punching bag of her on more than one occasion and with her face bettered in, her hair awry, and other parts of her anatomy sadly bruised and battered she decided last August to leave him."151

Alice Munro married her husband John in March 1905 and alleged that he began abusing her in September 1906. When she finally left him in July 1909, he had threatened to kill her with a razor. Mrs. Munro also accused her husband of not providing for the clothing and other necessities of life. ${ }^{152}$ Money was a major source of marital conflict and some women believed non-support was deliberate behavior by their husbands. Structural unemployment, which lasted longer than cyclical unemployment, intensified marital relations as unskilled workers found it more difficult to find jobs and replace lost income. ${ }^{153}$ Wives were financially dependent on their husbands and often pleaded with them for more money. This in turn made the husbands feel persecuted by the complaints and they retaliated in a violent manner.

As is evident in the examples provided, many women endured years of abuse before filing for divorce. The reality of the financial consequences of divorce prevented women from leaving abusive relationships sooner. Many women steered away from divorce because of the attitude that divorce broke a sacred marriage covenant. ${ }^{154}$ It was immoral to divorce and a woman or even the children of a woman whose decency was suspect were ill-treated.

Social stigma was not the only impediment to divorce in the early twentieth century, as financial ramifications also demanded consideration. Most women, especially women with small children, remained married to avoid extreme poverty and the accompanying hardship. While

151 "Defendant Turns Tables; Plaintiff in Divorce Tilt Julius Tort Beats His Wife's Action Friday, to File One Himself Yesterday Wants a Separation Without Alimony After Losing Out Twice May Schoonover Has Brought Her Third Suit For Divorce Against Her Husband Glen," Peoria Journal, February 6, 1910, evening edition. 152 "Says Her Husband threatened to Kill Reason Mrs. Alice Munro, of Edwards Station Asks For a Divorce," Peoria Journal, August 20, 1909, evening edition.

${ }^{153}$ Gordon, Heroes of Their Own Lives, 266.

${ }^{154}$ Gordon, Pitied But Not Entitled, 20. 
employment opportunities existed in Peoria for women, most did not provide adequate income for a single mother and her dependents. Mothers contemplating divorce had to consider the welfare of their children, including who would watch them if she went to work outside of the home. Illinois divorce laws granted both temporary and permanent alimony for wives but in working-class households, this amount could be minimal or nonexistent if the husband did not hold a steady job. ${ }^{155}$

Gertie Botts was a young girl from a working-class family who suffered from domestic violence and non-support throughout her short marriage. Her story demonstrates many of the issues that concerned social workers and illustrates the instability women experienced due to non-supportive husbands. It also shows the relationships between neighbors, friends, and families in a working-class neighborhood. Gertie (Slagle) Botts was found murdered in her room at a Monsoon Street boardinghouse. Alerted by the suspicious landlady after she witnessed a heated argument, police entered the Botts' room and found Mrs. Botts brutally murdered in her bed. The assailant had beaten her, shoved a man's handkerchief down her throat, covered her face with a pillow, and then strangled her to death with a hair ribbon. ${ }^{156}$ When compared to male/male assaults such as those that occurred at a saloon, domestic assaults were both more brutal and fatal. Men who did not use weapons in their domestic assaults thought they remained within the boundaries of a tolerable threshold. ${ }^{157}$ The only weapons Gertie's assailant used were fists and a hair ribbon, suggesting that the murder resulted from a domestic altercation. Police

\footnotetext{
155 Marriage and Divorce 1867-1906, 290.

156 "City Shocked By The Botts Murder Authorities Weaving A Web of Evidence Against Husband of Woman The Defendant's Statement Developments of the Coroner's Inquest Shows That After Leaving the House He Visited the Scene of the Crime," Peoria Journal January 7 1905, evening edition.

${ }^{157}$ Pamela Haag, "The "Ill-use of a Wife," Journal of Social History 25, no 3 (Spring 1992): 463.
} 
later found Otis Botts at the home of a friend, his face reportedly showed marks of being involved in a recent struggle.

The Botts had been residents of the boardinghouse for a while and other residents disclosed that it was common to hear the couple arguing. Domestic violence was a pervasive component of tenement life and neighbors were slow to intervene unless the violence passed a certain threshold of unacceptability. ${ }^{158}$ Gertie Botts was nineteen years old, and Otis Botts was twenty-one. They had been married less than a year and within the first few months of the marriage, Mr. Botts had driven Gertie Botts from their house with a revolver. ${ }^{159}$ Her father, Charles Slagle, a guard at the House of Corrections, testified that his daughter had returned to her family home upon leaving her husband because she feared for her life. ${ }^{160}$ Gertie Botts was lucky that she could return to her family home; however, it did not matter in the end. Many women in her situation did not have a family nearby they could rely on for support. These unfortunate women would have been left to fend for themselves or seek assistance from a charity organization. As historian Pamela Haag has contended, husbands in cases of domestic violence that ended in murder, "sought to underscore an unnegotiable right over wives and control of the private sphere by reveling in their capacity to determine the very life and death of their families." ${ }^{161}$ Otis Botts had repeatedly threatened his wife's life.

Mrs. Henry Ludwig, Gertie Botts' friend for eight years, testified that Mr. Botts was at times violently jealous of his wife and accused her of being unfaithful to him. ${ }^{162}$ She believed

\footnotetext{
${ }^{158}$ Haag, "The "Ill-use of a Wife," 463.

159 "City Shocked By The Botts Murder."

160 "Botts Faced with Alleged Confession Former Companion Says That He Told Of Killing Birdie Hoffman The Police Credit the Statement Sensational Testimony Developed at Morning's Hearing - Mrs. Ludwig Says that Slagle Threatened to Kill Daughter and Drove Her Away," Peoria Journal, January 9, 1905, evening edition.

${ }^{161}$ Haag, "The "Ill-use of a Wife," 463.

162 "Botts Faced With Alleged Confession Former Companion Says That He Told Of Killing Birdie Hoffman. The Police Credit The Statement Sensational Testimony Developed at Morning's Hearing - Mrs. Ludwig Says That Slagle Threatened to Kill Daughter and Drove Her Away," Peoria Journal, January 9, 1905, evening edition.
} 
that Mrs. Botts was faithful to her husband and the accusations against her were unfounded. The relationship between Mrs. Ludwig and Mrs. Botts illustrates the systems of support and rules of social relations that working-class women developed outside of their marriage that helped them manage the trials of daily life in a working-class neighborhood. ${ }^{163}$ Botts confided in Ludwig about her marital discord and relied on her friendship for encouragement.

Ludwig stated that the couple quarreled frequently because Botts would not keep a job and support his wife. He wrote letters daily to Gertie during a brief separation in which he begged her to return to him and promised he would change, get a job, and support her. The marriage contract was a woman's claim to economic security as both the working-class and middle-class believed that husbands should provide for their families. ${ }^{164} \mathrm{Mr}$. Botts' abusive behavior was contemptable but the unemployment was shameful as well to his wife's family and friends.

The Peoria Journal reported that Otis Botts was a known degenerate in the city of Peoria. ${ }^{165}$ He had been arrested four years earlier as an accessory to the murder of his girlfriend, Birdie Hoffman. He bragged to Gertie about committing this murder perhaps to frighten her into submission and to illustrate his dominance over her as a man. Botts was never tried for the murder due to the lack of evidence, however, many were certain of his guilt, including his young wife. It was disclosed that a few years after the Hoffman murder that Botts was in trouble again for the assault of a young girl. Police attempted to convince the young girl's mother to go after

\footnotetext{
163 Haag, "The "Ill-use of a Wife," 470.

${ }^{164}$ Haag, "The "Ill-use of a Wife," 467.

165 “City Shocked By The Botts Murder Authorities Weaving A Web of Evidence Against Husband of Woman The Defendant's Statement Developments of the Coroner's Inquest Shows That After Leaving the House He Visited the Scene of the Crime," Peoria Journal, January 7 1905, evening edition.
} 
Botts for the assault but she refused, afraid of what might happen to her daughter. Botts convicted of murdering his wife was hanged in the summer of 1905.

\section{VIOLENCE AGAINST WOMEN}

As is illustrated by the two women that Botts allegedly attacked before he killed his wife, unmarried women were also vulnerable to violent crimes. In August 1909, a former suitor attacked Miss Ethel Davis, an employee of a downtown Peoria department store, on a public street. Both Davis and the beau were arrested for disorderly conduct. ${ }^{166}$ The fact that both the man and woman were arrested demonstrates the attitude that the police had toward young women out on the streets at night. The credibility of a victim was often questioned in these situations because authorities believed that a respectable woman would not be walking the streets and talking to men after dark. ${ }^{167}$ Organizations such as the Y.W.C.A. and the Travelers' Aid Committee attempted to protect young women like Davis from dangerous men. ${ }^{168}$

Davis was probably an innocent young woman, unlike Carrie Ferris who was also assaulted by a known acquaintance. Rolla Johnson, a saloon owner, assaulted Fisher, a prostitute, in a drunken rage. ${ }^{169}$ The chief of police closed the saloon and stated that Johnson would not be allowed to reopen it. As Carolyn Strange has noted, police were reluctant to arrest men if the complainant was a woman of questionable character. ${ }^{170}$ Defense lawyers eager to deflect from an assailant's crime easily dismantled the credibility of such witnesses in court. The Peoria Journal reported that Johnson had been making trouble in Peoria for many years. He first came to Peoria as a barber and married the owner of a brothel. According to the newspaper, his wife died

\footnotetext{
166 “J.H. Boswell Beats Up Ethel Davis Because Of A Rival,” Peoria Journal, August 18, 1909, evening edition.

167 Strange, Toronto's Girl Problem, 53-54.

168 Meyerowitz, Women Adrift, 49.

169 “White Slave Is Beaten Almost To Pulp; May Die Rolla Johnson In A Drunken Rage Inflicts Possibly Fatal Injuries On Woman Mrs. Tyngblade Is Victim Of His Wrath Assault Occurred In Rooms Over His Saloon Which Is Closed By Chief Of Police Rhoades," Peoria Journal, February 26, 1910, evening edition.

${ }^{170}$ Strange, Toronto's Girl Problem, 66.
} 
mysteriously and Johnson inherited two brothels on North Washington Street and a fancy house on Monroe Street. The Peoria Journal reported that Johnson "has always borne the worst possible character as a white slaver, a menace to society and with the money inherited through the strange death of the Johnson woman, a leader in the class that preys on men and women alike." ${ }^{171}$ Perhaps Johnson's troublesome reputation convinced the Peoria police to act on Ferris' charge.

Madams and prostitutes were especially vulnerable to violent attacks by men due to their work in the vice district and police seldom took their complaints seriously. ${ }^{172}$ Working in Peoria's red-light district made women an easy target and their suspect reputation damaged their believability when they were pitted against the reputations of prominent citizens. In 1906, angry male customers, all considered prominent Peoria citizens, attacked Gale Brownley, the owner of a brothel on North Washington Street. A resident of the brothel named Leona joined in the fray to help Brownley and was so severely injured that she required surgery. The assailants were taken to jail but the local newspaper questioned if the matter would end up in court despite the severe beatings the women received. ${ }^{173}$ Women of disreputable character did not stand a chance in cases against respectable community members. Their already marred public identity challenged existing social structures and it was difficult for them to receive fair dealings in the

\footnotetext{
171 "White Slave Is Beaten Almost To Pulp; May Die Rolla Johnson In A Drunken Rage Inflicts Possibly Fatal Injuries On Woman Mrs. Tyngblade Is Victim Of His Wrath Assault Occurred In Rooms Over His Saloon Which Is Closed By Chief Of Police Rhoades," Peoria Journal, February 26, 1910, evening edition. Johnson's saloon was at 228 North Adams Street and the two brothels were at 307 and 309 North Washington Street.

${ }^{172}$ Strange, Toronto's Girl Problem, 67.

173 "Noble Scions In A Hot Fight Warm "Diddings" At The House of Gale Brownley May Result in Prosecutions in a Few Days," Peoria Journal, April 1, 1906, evening edition.
} 
criminal justice system. Because these women had limited social, political, and economic status it was difficult to mobilize legal assistance on their behalf. ${ }^{174}$

Women who owned and operated businesses in Peoria's vice district were often brutalized. In March 1906, a long time saloon employee, Meent De Vries, attacked the owner of the Klondike saloon, Mrs. Anna Haaren, and her twenty-year-old daughter in the middle of the night. De Vries had operated the saloon for Mrs. Haaren for several years and boarded in rooms over the saloon. As witnessed by Mrs. Haaren's twenty-two year old son, De Vries in a drunken stupor entered the rooms where the Haaren family slept and threatened to kill them with a hatchet. Acting in self-defense, the son shot De Vries with a revolver and killed him instantly. ${ }^{175}$ In his statement to the police, the son alleged that it was common for De Vries to drink with a crowd of men but recently he had become quarrelsome when he drank. This confirms Gordon's contention that saloon camaraderie escalated men's hostility toward women. ${ }^{176}$ Both De Vries and the Haaren family were recent immigrants from Germany and had known each other since at least 1898 , which makes the seemingly unwarranted violent attack even more confusing. ${ }^{177}$

\footnotetext{
${ }^{174}$ Anne M. Butler, Gendered Justice in the American West: Women Prisoners in Men's Penitentiaries, (Urbana: University of Illinois Press, 1997), 82 and 88. See also Mara L. Dodge, Whores and Thieves of the Worst Kind: A Study of Women, Crime, and Prisons, 1835-2000 (DeKalb: Northern Illinois University Press, 2002).

175 "Drunken Orgy Ends In Murder Meent DeVries Killed by Harold Haaren In The Klondike Saloon Attacks Mother and Sister Murderer Claims That He Committed Deed in Self-Defense - Prisoner in City Lockup," Peoria Journal, March 25, 1906, evening edition.

${ }^{176}$ Gordon, Heroes of Their Own Lives, 265.

177 Ancestry.com. U.S. and Canada, Passenger and Immigration Lists Index, 1500s-1900s [database on-line]. Provo, UT, USA: Ancestry.com Operations, Inc, 2010. The Haarens immigrated from Germany in 1891 and DeVries just two years later. Anna, already widowed, was first listed in the Peoria City Directory in 1895 living on South Washington Street. In 1898, the family resided at 1701 South Adams Street the same residence as Frederick De Vries, saloon owner. Meent De Vries lived at the same address but his occupation was listed as a laborer. The following year, Meent De Vries was listed as a saloon proprietor at 703 Starr Street and the Haaren family was listed as residing at the same address. By 1900, De Vries and the Haaren family were established at the 733 Starr Street Address where De Vries died six years later. After De Vries death, the Haaren family continued to operate the Klondike and the 1910 U.S. Census recorded Anna, Harry, and Catherine still operating and living above the saloon with Harry listed as the bartender. No one will ever know what prompted De Vries' attack on the Haaren family but their common German heritage might have been a contributing factor. Being raised in the German culture, De Vries may have naturally resented working for a woman even though women were generally welcomed in German beer gardens. The saloons location in a working-class neighborhood would have attracted a large German clientele and perhaps the attack was truly the result of drunken rowdy comradery. The record of two families' manner of living
} 


\section{ALCOHOL ABUSE}

Alcohol was both a symptom and a remedy for many of the ills that immigrant and urban poor families faced, including stress, hopelessness, tiredness, illness, depression, and hunger. ${ }^{178}$ Matron Mayall observed, "After thorough investigation I find that the excessive use of liquor in the family is the real cause of destitution and delinquency, and crime is almost the inevitable result. In many instances the mother imbibes herself, and her home is one of disorder and filth, the real necessities of life are withheld from the family, and the children are left to shift for themselves." ${ }^{179}$ Officials believed that the frequent and heavy consumption of alcohol among the working-class families in Peoria contributed to the poverty, misery, and abuse experienced by many women and children. In 1909, over 1,000 men and women were arrested in Peoria for drunkenness or drunk and disorderly conduct and by 1912 that number had risen to over 1,600. ${ }^{180}$ Alcoholism was a nationwide issue among the poor and working-class in the years leading up to the Prohibition era, 1919-1933. Alcohol not only ate away at the family budget but it caused pain and illness that affected family members and deprived them of support. Social workers found heavy drinking often contributed to physical-neglect cases as alcoholic parents often had the dirtiest homes and most neglected children. ${ }^{181}$

Women drank differently than men. They drank in the privacy of their homes and more often alone. Women in family-violence cases drank more heavily than other women. ${ }^{182}$ The

\footnotetext{
and working together as well as sharing strong cultural ties adds confusion to the death of the twenty-five year old man.

${ }^{178}$ Gordon, Heroes of Their Own Lives, 142.

${ }^{179}$ Anna M. Mayall, "Report of Police Matron," in City Comptroller's Report Statement of the Finances of the City of Peoria for the Fiscal Year Ending December 31, 1909 Together with the Reports of the Various Departments (Peoria: Brown-Williams Printing Co, 1910), 185-186, 190.

${ }^{180}$ Anna M. Mayall, "Report of the Police Matron," in City Comptroller's Report Statement of the Finances of the City of Peoria for the Fiscal Year Ending December 31, 1911 Together with the Reports of the Various Departments (Peoria: Brown-Williams Printing Co, 1912), 119-121.

${ }^{181}$ Gordon, Heroes of Their Own Lives, 144.

${ }^{182}$ Gordon, Heroes of Their Own Lives, 145.
} 
conditions in the Bowers' Peoria home demonstrates this perfectly. In the winter of 1910, neighbors called Matron Mayall to investigate the home of Mrs. William Bowers who reportedly beat her elderly mother-in-law, Almira Bowers. When Mayall arrived, she found the Mr. and Mrs. heavily intoxicated and Almira Bowers lying on the floor badly beaten. Purportedly, Mrs. William Bowers became angered and attacked her mother-in-law when she corrected one of her grandchildren. Almira Bowers had been living at the county poor farm until recently when her son brought her to live in his home. Almira Bowers was the widow of a Civil War veteran and received a pension from the government; she claimed that her son removed her from the poor farm only to get her pension and then used it to buy whiskey. The Peoria Journal reported that Mayall removed Bowers' two small daughters and placed them in a suitable foster home and returned the elderly woman to the poor farm. ${ }^{183}$

U.S. Census records and the Peoria City Directory indicated that William Bowers held a variety of jobs, including the driver of an ice truck, a laborer for a paper company, and as a porter in a barbershop. ${ }^{184} \mathrm{He}$ and his wife, who were married for over twenty-one years, resided in the rear of a house that was next to the C.RI. \& P.R.R tracks and immediately across the tracks from the Detweiller Ice Company where he was employed for many years. ${ }^{185}$ The records show that sometime between 1910 and 1917, the couple separated, and Bowers moved into the home of his younger brother, Frank Bowers. During this transitionary time, Bowers, already in his forties, became a laborer for a paper company, and his wife and their children disappeared from

\footnotetext{
183 “Drunken Woman Beats Up Her Mother In A Brutal Manner,” Peoria Journal, February 12, 1910, evening edition.

${ }^{184}$ Thirteenth Census of the United States, 1910, (National Archives and Records Administration microfilm publication T624_315; page 15A; Enumeration District: 0068; FHL microfilm: 1374328)

https://search.ancestry.com/cgi-

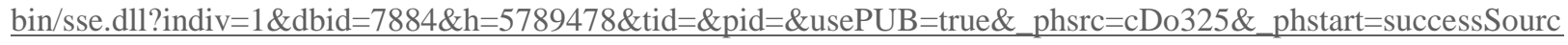
e and Peoria City Directory, 1906, 1907, 1908, 1909, 1917, 1922, 1923, 1924, 1926, 1928, 1929

${ }^{185}$ University of Illinois Digital Collections, Insurance Maps of Peoria Illinois, (New York: Sanborn Map Co, 1902), 109 https://digital.library.illinois.edu/items/c553ef30-c451-0133-1d17-0050569601ca-0
} 
the public eye. Many reformers believed that family weakness was the cause of larger social problems, which could be resolved by reforming the family. ${ }^{186}$ In the case of the Bowers family, the solution meant protecting the children by removing them from the violence and alcohol that was evident in the home. In the eyes of middle-class social workers, mothers were more responsible for the care of the children and therefore when neglect or abuse occurred in a twoparent home the mothers were often to blame. By removing the Bowers children from the home, Police Matron Mayall may have been trying to save the girls from a future in prostitution; a fate experienced by many young girls raised in working-class homes where alcohol played a prominent role in family life.

\section{ILLEGITIMACY}

Not all working-class families in Peoria experienced desertion, divorce, domestic violence or alcohol abuse but their lives were still touched by instability and hardship. The family life of Anna Lehan and her premature death following an illegitimate pregnancy illustrates social workers' concerns surrounding illegitimacy. Though raised in a two-parent household, Lehan still experienced instability in her home as the family moved frequently and every member of the family worked from a young age to contribute to the family income. Her unwed pregnancy further demonstrates the perils that young single working girls faced. Had Lehan been raised in a more stable environment and not been working at such a young age her story might have had a different ending.

Daniel Lehan and Margaret F Mitchel, both the children of Irish immigrants, married in 1880 in Livingston County, Illinois. The 1900 U.S. Census lists the family living on a farm in

\footnotetext{
${ }^{186}$ Gordon, Heroes of Their Own Lives, 72.
} 
Richwoods, Peoria County, Illinois with seven children. ${ }^{187}$ Daniel Lehan worked as a foreman on the railroad and his oldest son John only eighteen worked as a flagman. Other children in the household include Anna, age sixteen, Mary M age fourteen, Daniel Jr. age twelve, Lawrence age ten, Ellen age seven, and Peter age five.

The Lehan family like many working-class families moved regularly, rarely owning their residence, and each member of the family worked and contributed to the family economy. Anna and Mary Lehan worked in candy companies while their older brothers joined their father working on the railroad. ${ }^{188}$ The fact that all members of the Lehan family worked, even though the father was continually employed in a good trade, illustrates how difficult it would have been for a single mother to scrimp by in Peoria on the wages of a woman, which would have been considerably lower than what Mr. Lehan earned on the railroad.

The year of 1909 brought great tragedy to the Lehan family when twenty-six year old Anna Lehan died as the result of a botched abortion. According to the Peoria Journal she confessed to doctors on her deathbed that Mrs. Isabella Romine had twice attempted to perform an abortion on her. ${ }^{189}$ She died after the second attempt. The Peoria Journal reported, "The young girl's story was pitiful in the extreme. Grossly betrayed she was advised to go to this woman. She did but the operation failed the first time. She went again and this time it was successful as criminal operations go - successful in bringing death to her and sorrow and shame

\footnotetext{
187 Twelfth Census of the United States, 1900, (National Archives and Records Administration microfilm publication T623; page 7; Enumeration district: 0123; FHL microfilm: 1240335) https://search.ancestry.com/cgi-

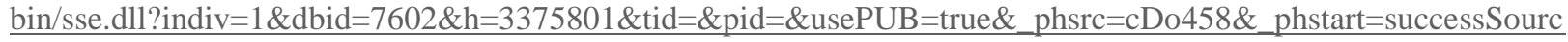
$\underline{\mathrm{e}}$

${ }^{188}$ Franks Peoria City Directory Vol XXIV 1905 Directory of the Citizens, (Peoria: J.W. Franks \& Sons, 1906). White's Peoria City Directory Vol XXV 1906 Directory of the Citizens, (Peoria: John A White, 1906). White's Peoria City Directory Vol XXVI 1907.

189 "Error Of Doctors Probably Defeats Ends Of Justice Failed To Notify States Attorney Of The Approaching Death Of Anna Lehan No Official Death Statement Is Taken Destroys Evidence Against Isabelle Romine Of North Street Whom The Girl Named At Hospital," Peoria Journal, February 18, 1910, evening edition.
} 
on her family." 190 Involuntary motherhood for a single woman was disastrous. Not only did pregnancy bring shame on the family but it also meant missed wages, possible loss of job, and additional expenses to feed, clothe, and house a child. ${ }^{191}$ Pregnant women sought illegal abortions to escape their dire circumstances, just as Anna Lehan resorted to the backdoor services of another working-class woman.

Isabella Romine, also known as Matilde Romine and Annabelle Long, was accused of performing the operation that ended the life of both the baby and mother. The instruments used to perform the abortion were found in her home, but Romine claimed to run a boarding house and that the instruments belonged to a boarder that lodged there. ${ }^{192}$ The fact that Romine operated a boarding house and was accused of performing an abortion validates some of the fears that social workers had concerning women who took in boarders. Carolyn Strange discovered in her examination of abortion cases in Toronto that police preferred to prosecute the abortionists and not the client attempting to secure an abortion because of the popular belief that young women in the city were naïve victims. ${ }^{193}$ The state's attorney investigated Mrs. Romine for the crime.

\section{WOMEN WORKING IN THE RED-LIGHT DISTRICT}

The account of Isabella's life in Peoria is an example of the hardship that some workingclass women experienced and the illicit activities they resorted to in order to earn a living. The 1900 United States Census lists the family of Belle Romine living on Monson Street in Peoria.

\footnotetext{
190 “Officials Probe The Sudden Death Of Anna Lehan Passes Away At the St. Francis Hospital Following A Criminal Operation Woman On The Bluffs Is Held Responsible Girl Made A Dying Statement To The Attending Physicians And Sister At Hospital," Peoria Journal, February 17, 1910, evening edition.

191 Strange, Toronto's Girl Problem, 69.

192 Mrs. Romine Takes Stand; Refuses To Make Answer On Advice Of Her Attorney She Maintains Silence Before The Corner Investigating Death Of Miss Anna Lehan Jury Holds Dr. Kerr and Authorities of St. Francis Hospital Guilty Of Neglect In Not Reporting Case,” Peoria Journal, February 19, 1910, evening edition.

193 Strange, Toronto's Girl Problem, 70.
} 
Romine lived with her husband Preston, who worked as a janitor. The Romine's had two children, Beulah and Jacaria, living in the home. ${ }^{194}$ Review of multiple years of the Peoria City Directory tells a confusing story about the family. Beginning in 1907, Isabella Romine was listed as a widow but a Preston Romine was recorded in the city directory consistently from 1897 through 1919 when he died. ${ }^{195} \mathrm{He}$ was listed off and on as a laborer or janitor and never lived at the same address for more than a year or two. Isabella Romine does not appear consistently in the directories but she and daughter Beulah share the same address in 1907. Beulah Romine and her brother lived at the same address in the 1905 directory but neither parent is listed in this edition. Whether Isabella Romine was widowed or deserted by her husband, it is evident that she supported herself in Peoria for multiple years. Perhaps she performed abortions out of sheer desperation in an attempt to make ends meet.

Many women like Gale Brownley, Anna Haaren, and Isabella Romine owned and operated businesses in Peoria's red-light district for years. Some such as Bertha Frankenstein a.k.a. Bertha Kashjen even expanded their businesses to red-light districts in neighboring cities and appeared to exercise some power. Bertha Frankenstein lived in Peoria but owned two properties in Peoria, two in Pekin, and one in Bloomington, which she rented out as brothels. ${ }^{196}$ She was arrested in January 1910 for attempting to place a fifteen-year-old girl, Pearl Patterson Harrison, in a brothel, which operated on property that she owned in Bloomington.

\footnotetext{
${ }^{194}$ Twelfth Census of the United States, 1900, (National Archives and Records Administration microfilm publication T623; page 9; Enumeration district: 0102; FHL microfilm: 1240334) https://search.ancestry.com/cgi-

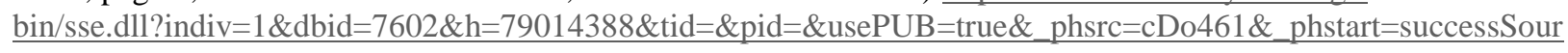
$\frac{c e}{195}$

$\frac{\overline{195}}{19}$ Ancestry.com. U.S. City Directories, 1822-1995 [database on-line]. Provo, UT, USA: Ancestry.com Operations, Inc., 2011. https://www.ancestry.com/search/?name=preston_romine\&event=_peoria-peoria-illinois-

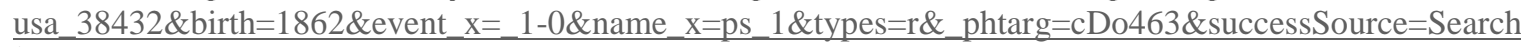
196 "Peoria Woman Talks Mrs. Frankenstein-Kashjens Says She Was Innocent of Enticing Pearl Patterson to Bloomington," The Pantagraph, January 14, 1910.
} 
The Bureau of Associated Charities and the Humane Society joined efforts in an attempt to prove that Patterson was only fifteen years old even though she was previously married and claimed to be eighteen. The Associated Charities provided records from the Peoria Public Schools that Patterson had once attended, as well as their own records from a time when they had provided services to the Patterson family, all showing that the girl was only fifteen. Patterson's parents, her married elder sister, an aunt, and several friends and former neighbors of the family testified in court that she was eighteen years old. The Associated Charities claimed that Bertha Frankenstein was paying the girl's family and friends to lie about her age to keep Frankenstein out of trouble. The Pantagraph reporter further speculated that Frankenstein owned multiple properties used as brothels and therefore she "has money to invest in the Pattersons if she sees fit." ${ }^{197}$ If it were proven that Patterson was underage and Frankenstein was convicted of pandering, her sentence would have been severe. ${ }^{198}$ The jury determined that Patterson was underage, and she was placed in the Home of the Good Shepherd in Peoria. Court officials declared since Patterson would be a witness against Frankenstein that it would be best if she remained at the Home until after the trial. ${ }^{199}$

Frankenstein was indicted for pandering but never went to court. Pearl Patterson disappeared and could not testify against Frankenstein making it difficult to prove her guilt. The McLean County judge made a deal with Frankenstein, which allowed her to escape jail time if she pleaded guilty. She was fined seven hundred dollars and court costs even though the crime

\footnotetext{
197 “Age Of Girl To Decide Delinquency Hearing In Patterson Case Interesting Testimony Heard In the Case Of Pearl Patterson, Brought Here For Immoral Purposes," The Pantagraph, January 19, 1910.

198 "Mrs. Frankenstein Has Been Arrested For Brining Patterson Girl Here New Developments Came Rapidly Yesterday and Last Night - Age of Girl is 15 Years," The Pantagraph, January 6, 1910.

199 "Pearl Patterson Place In Home Of Good Shepherd Bloomington Jury Find She Is Not Yet Sixteen Years Of Age, According To The Records Relative All Swore She Was Nineteen Will Be Held Here To Be Used As A Witness Against Bertha Frankenstein In Crusade Being Waged Against White Slavery," The Pantagraph, January 20, 1910.
} 
was punishable by a term in the penitentiary. ${ }^{200}$ The Pantagraph asserted, "It was freely predicted and stated at that time that Bertha Frankenstein's money was behind the resistance of the delinquency charge against the girl and that if sharp watch was not kept, that Pearl Patterson would be missing when the time came to try the case of the woman charged with the crime against her." Patterson was allowed to leave the Home of the Good Shepherd with her mother supposedly to attend court in Bloomington and never returned. The Peoria Journal conjectured that Frankenstein or her agents spirited the girl away to keep her from testifying.

Young working-class women like Pearl Patterson had countless obstacles to overcome and many nefarious people, both men and women to guard against. Madams were constantly replenishing their houses with new residents and young girls desperate to make money were easy targets. Bertha Frankenstein and Nettie Clark were only two of a host of women who owned or operated brothels in the Peoria area. Mattie Cooksey conducted a "cathouse" on Walnut Street in Peoria. She and her residents were arrested in June 1906 during a police raid. ${ }^{201}$ Mattie posted bond for herself, her employees, and her boyfriend, also arrested during the raid. The establishment of Miss Ethel Summers on North Washington Street was the site of a fatal shooting in June $1906 .{ }^{202}$ Several people were arrested at the time including an African American employee and a resident, Lenora Jackson. Miss Mabel Morris, another resident of Summers' establishment, paid the bond for Jackson and the helper on behalf of Summers. Both Morris and Jackson in their statements to the police mentioned a dance hall located near the brothel that they frequented.

\footnotetext{
200 “Mrs. Frankenstein Pays A Fine Of Seven Hundred Peoria Woman Pleads Guilty To A Charge Of Pandering At Bloomington Pearl Harrison Missing At Trial Authorities Agreed To Wave A Prison Term Because Of Absence Of Sixteen Year Old Girl," Peoria Journal, February 27, 1910, evening edition.

201 "Police Raid The Place Dive of Mattie Cooksey Was Pulled Last Night," Peoria Journal, June 3, 1906, evening edition.

202 “Thomas Littleton is Shot and Mortally Wounded By Bert M. Osborne In Summers' Dive," Peoria Journal, June 4, 1906, evening edition.
} 
Often madams operated bawdy houses under the guise of a boarding house. Anna Snyder, an African-American operator of a boarding house, was arrested multiple times, but never convicted, on the charge of running a "fancy" house. ${ }^{203}$ Examination of a single ledger page of the Thirteenth Census of the United State: 1910 for the city of Peoria shows four boarding houses side by side on the two hundred block of Washington Street all with female keepers and all single female boarders ranging in ages from twenty to twenty-six. ${ }^{204}$ On the three hundred block of Washington, the Census ledger shows the same scenario for six boarding houses. Georgia Hall, one of the boarding house keepers operating on Washington Street, admitted during testimony to the Illinois Senate Vice Committee that she had kept a house of prostitution for twenty-two years. A Mrs. Armstrong actually owned the house Hall operated out of and had run the business prior to Hall taking it over. ${ }^{205}$ According to historian Neil Shumsky, brothels tended to be clustered together in urban areas for three reasons. One, prostitutes chose to cluster in areas that were good for business and where the greatest number of potential clients could be found. Two, municipal officials and policemen, realizing that prostitution could not be abolished but at least controlled, confined brothels to certain areas within a city so that they could manage them better. Lastly, concerns over health regulations and especially venereal diseases produced a desire to regulate prostitution and provide health examinations, both of which would be simpler if the prostitutes were confined to a certain local. ${ }^{206}$ The locations along Washington Street

\footnotetext{
203 “Anna Is Freed Again Second Jury Decides She Is Not Running Disorderly House,” Peoria Journal, June 8, 1906, evening edition.

${ }^{204}$ Thirteenth Census of the United States, 1910, (National Archives and Records Administration microfilm publication T624_316; page 4A; Enumeration District: 0076; FHL microfilm: 1374329)

https://search.ancestry.com/cgibin/sse.dll?indiv=1\&dbid=7884\&h=5797209\&tid=\&pid=\&usePUB=true\& $\&$ phsrc $=$ cDo472\&_phstart=successSourc ${ }^{\mathrm{e}}{ }^{05}$ Report of the Senate Vice Committee, 330.

${ }^{206}$ Neil Larry Shumsky, "Tacit Acceptance: Respectable Americans and Segregated Prostitution, 1870-1910," Journal of Social History 19, no 4 (Summer 1986): 665.
} 
where these "boarding houses" existed was within the limits of Peoria's red-light district and demonstrated the thinking as outlined by Shumsky. Red-light districts were economic and social ghettos that segregated the lower and working-classes and provided a means of controlling them. ${ }^{207}$ These examples of women running brothels disguised as boardinghouses in Peoria justified social workers suspicions of women who took in boarders.

Many working-class women in Peoria lived a poor and miserable existence, working poor paying jobs to support themselves and their children. Their dismal situation often resulted from the non-support of a husband or father via desertion or divorce. Violence and alcohol abuse escalated instability in the homes and troubled social workers who attempted to assist impoverished families. Social workers concern over desertion, illegitimacy, access to mothers' pensions and employment for single mothers were substantiated in the homes of many Peoria working-class families. Life in Peoria's working-class neighborhoods was taxing for women and many turned to charities and civic organizations for help.

${ }^{207}$ Shumsky, “Tacit Acceptance: Respectable Americans and Segregated Prostitution”, 665-666. 


\section{CHAPTER IV: PROGRESSIVE-ERA REFORMERS IN PEORIA}

In March 1906, over one thousand Peoria women signed a petition asking the mayor to suppress gambling, wine rooms, and other forms of vice and calling for better enforcement of laws regarding Sabbath observation. ${ }^{208}$ Days before the submission, Captain Houston, a Chicago evangelist, addressed several women's groups in Peoria and encouraged them to publicize their opinions against the indecent practices of the red-light district and to join together to restore moral order in Peoria. Houston's address detailed his recent visit to the red-light district of Peoria where he observed prostitutes walking freely about and alcohol sold to minors. ${ }^{209}$ Soon after his visit, concerned women created pamphlets, which they distributed throughout Peoria. Their message announced reform efforts, including information on Illinois gambling laws, in an effort to spread the sentiment against vice in Peoria. Their correspondence with the Illinois Attorney General and petitions to Mayor Tolson, demonstrate their ability to influence legislation and make an impact on the community through raising awareness on the regulation of vice. The Peoria Journal reported, "The spirit of the meeting indicates that the women have started their campaign to win."210

This chapter examines the Progressive-Era reformers in Peoria, who, in addition to cleaning up vice districts, worked to elevate the dismal circumstances of wage-earning women and their dependents. Records from private community organizations, from national rescue homes with locations in Peoria, and state legislative actions directed at curtailing the vice industries illustrate the variety of efforts directed at easing the burdens of working women.

\footnotetext{
208 "Mayor Prepares His Answer," Peoria Journal, March 24, 1906, evening edition.

209 "Capt. Houston on the Wine Rooms: Executive Committee of Women's Meeting to Scatter Printed Matter about the City," Peoria Journal, March 22, 1906, evening edition.

210 "Women have Plan Afoot: Will Issue Literature - Mayor's Letter Received," Peoria Journal, March 29, 1906, evening edition.
} 
Most historians, who have studied similar kinds of moral reform movements, have focused on efforts at a national level or in major cities such as Chicago, New York, or Los Angeles. However, studying these reform efforts in a smaller city is beneficial as it allows us to see these national ideas implemented at a grass roots level. When we study smaller cities like Peoria, the localism of reform efforts becomes more apparent. Peoria faced problems similar to those in other cities such as alcohol abuse, the presence of prostitution in neighborhoods, men deserting their families, and women forced into the workforce. By studying the work of reformers in Peoria regarding these national issues we see how local organizations tailored efforts to address these national problems by creating organizations and harnessing the power of the state in new ways to target the issues that effected Peoria the most. It also authenticates the claim that these were indeed nationwide issues and not just unique to metropolises. ${ }^{211}$ In addition, several local efforts in Peoria shaped state legislative agendas.

\section{COMMUNITY ORGANIZATIONS IN PEORIA}

The women who signed the petition and spearheaded the campaign against vice in Peoria were part of a new generation of reformers, who focused on mending social problems that accompanied rapid urban growth and industrialization in the late nineteenth century. ${ }^{212}$ Historians have long debated the effects of Progressive-era actions and the presence of reformers in cities. Starting with Robert Wiebe's, The Search for Order, historians examined these actions of reformers from the perspective of how their actions influenced city agendas. ${ }^{213}$ However,

\footnotetext{
${ }^{211}$ For more information about the agendas of Progressive reformers see Elizabeth Clapp, Mothers of All Children Women Reformers and the Rise of Juvenile Courts in Progressive Era America (University Park: The Pennsylvania State University Press, 1998), Gordon, Heroes of Their Own Lives, Elizabeth Lunbeck, The Psychiatric Persuasion Knowledge, Gender, and Power in Modern America (Princeton, New Jersey: Princeton University Press, 1994), May, Unprotected labor, Meyerowitz, Women Adrift, Odem, Delinquent Daughters, and Strange, Toronto's Girl Problem.

212 Odem, Delinquent Daughters, 99.

${ }^{213}$ For more information on how reformers influenced city agendas see Robert Wiebe, The Search for Order, 1877 1920 (New York: Hill and Wang, 1967), Alan Trachtenberg, The Incorporation of America: Culture and Society in
} 
women's historians have emphasized the central role middle-class women played in these reform movements. ${ }^{214}$

The progressive movement was an attempt by middle-class Americans to bring order to a chaotic society. Late nineteenth century Americans lived in an industrialized society with a distinct middle class stranded between two extremes, the exceptionally rich and the dreadfully poor. The middle class recognized unruly predicaments created by industrial capitalism and attempted to bring order to these dilemmas by changing the other classes to fit into their middle class ideal. Essentially these progressives sought to gain control of a situation that seemed uncontrollable by traditional means. Upper- and middle-class Americans were anxious over the decline of the traditional family life. They utilized tools such as associations and the government to bring the chaos into order, employing new and seemingly innovative tactics to curb the mayhem. Some of their endeavors were successful and had lasting effects, others faded into obscurity. $^{215}$

Most of these progressive reformers were middle-class men and women who worked toward political, economic, and social reform; but female reformers dominated these efforts and used their traditional sphere of influence in the home to concentrate their efforts on initiatives that primarily addressed the woes of urban women and children. Such issues included child

the Gilded Age (New York: Hill and Wang, 1982), and T. J. Jackson Lears, Rebirth of a Nation: The Making of Modern America, 1877-1920 (New York: Harper Collins, 2009).

${ }^{214}$ For more information on women's historians who focused on working-class women and their needs see Maureen Flanagan, America Reformed: Progressives and Progressivisms (New York: Oxford University Press, 2007), Rebecca Edwards, New Spirits: Americans in the Gilded Age, 1865-1905 (New York: Oxford University Press, 2006) and Jamie Schmidt Wagman, "Women Reformers Respond during the Depression Battling St. Louis's Disease and Immorality." Journal of Urban History 35, no. 5 (July 2009): 698-717.

${ }^{215}$ For more information on progressive reform, see Steven Diner, A Very Different Age: Americans of the Progressive Era, (New York: Hill and Wang, 1998), Michael McGerr, A Fierce Discontent: The Rise and Fall of the Progressive Movement in America, 1870-1920, (New York, Free Press, 2003), and Roy Rosenzweig, Eight Hours for What We Will: Workers and Leisure in an Industrial City, 1870-1920, (Cambridge: Cambridge University Press, 1983). 
labor, juvenile delinquency, the spread of prostitution, unsanitary housing, low wages, concerns with domestic violence, unwed pregnancy, and poor working conditions for female laborers. The pervasiveness of the separate spheres and maternalistic ideologies influenced how reformers addressed social problems in Peoria. However, the ideal sometimes clashed with the realities of working mother's lives. The role of the mother as the keeper of the sanctity of the home was key to the reformers actions. The Peoria Women's Civic Federation, a progressive association, led initiatives to combat many of these problems in Peoria.

The growth of women's organizations in the late nineteenth and early twentieth centuries resulted in part from changes that occurred in middle-class homes that gave women more time and desire to engage in activities outside of their home. This is reflected in the Y.W.C.A. handbook that justified female middle-class volunteerism because domestic duties such as teaching children, baking, and sewing now were performed by others which freed women to participate in volunteer activities. ${ }^{216}$ Many educated, upper- and middle-class women from both white and African American communities joined associations for female companionship, social standing, and intellectual stimulation. ${ }^{217}$ These groups that started out as social outlets or indicators of prestige evolved into mechanisms for social and political change when women became earnest in their efforts to correct the ills of society. Three stages of the club movement in the Midwest involved first creating a club for educational and intellectual betterment of its members, then moving the club away from self-culture and toward service, and finally acquiring

\footnotetext{
${ }^{216}$ The Handbook of the Young Womens Christian Association Movement Prepared under the auspices of the Department of Method of the National Board (New York: National Board of the Young Womens Christian Association of the United States of America, 1914), 2.

${ }^{217}$ Clapp, Mothers of all Children, 22.
} 
power through a united effort to effect municipal, state, and national affairs. Cooperation among multiple clubs made the third stage possible. ${ }^{218}$

Several characteristics distinguished this generation of reformers from earlier activists: first, Progressive reformers used the techniques of empirical research and sociological investigation to study society; second, they viewed poverty and unemployment as the result of environmental forces of which the poor had little control; and lastly, they offered new solutions to the social problems they addressed. ${ }^{219}$ As demonstrated by the female reformers in Peoria, Progressives used the state and local governments to intervene in social and economic issues for the common good. They utilized committees or task forces, like the Illinois Senate Vice Commission and the Illinois Industrial Survey commission, to examine social problems and relied on trained experts to develop and administer policies that came out of the commissions' investigations.

\section{PEORIA WOMEN'S CIVIC FEDERATION}

Delegates from twenty different women's organizations in Peoria came together in the spring of 1905 to form the Peoria Women's Civic Federation (PWCF). ${ }^{220}$ A local organization similar to the Chicago Woman's Club, the purpose of the PWCF was to improve, expand, and create an understanding of the problems that affected Peoria women, their families, and their homes. ${ }^{221}$ Their own identification as mothers and their perceptions of family life and childhood

\footnotetext{
${ }^{218}$ Mrs. John Dickinson Sherman, "The Womens Club in the Middle Western States," The Annals of the American Academy of Political and Social Science 28, (September 1906): 30.

${ }^{219}$ Odem, Delinquent Daughters, 100.

220 Julia Proctor White, "History of the Peoria Women's Civic Federation 1905-1955," 2. The twenty founding clubs were: As You Like It Club, Catholic Women's League, College Club, Current Event's Club, Daughters of the American Revolution, Friday Club, Kindergarten Teachers' Club, New Era Club, North Peoria Women's Club, Outlook Club, Peoria Kindergarten Association, Peoria Mothers' Club, Peoria Women's Club, Research Club, West Bluff $19^{\text {th }}$ Century Club, Women's Christian Home Mission, Women's Christian Temperance Union, Women's Protective Agency, Women's Society of German Free School, Young Women's Temperance Union.

${ }^{221}$ Maureen A. Flanagan, Seeing with Their Hearts: Chicago Women and The Vision of the Good City, 1871-1933, (Princeton, N.J.: Princeton University Press, 2002), 32.
} 
moved upper- and middle-class women to take action on behalf of women and children who lacked the wherewithal to change their circumstances. They were dedicated to their traditional views of motherhood and domesticity but believed modern times required them to extend their maternal instincts beyond their own home and to apply their domestic values to society. ${ }^{222}$ The Peoria Women's Civic Federation existed to strengthen the effectiveness of women's efforts through unification and to use robust political action to make a difference in the lives of working-class women and children. The federation encouraged clubwomen to "assume the obligation of alert, clear-sighted citizenship; for, to protect our home-life and our privileges as Americans, women must take an active interest in all that happens today, starting with the grassroots level in Peoria." 223 Many of the clubs had worked together successfully earlier in the year to lobby for the appointment of a truancy officer, Mrs. Stouffer, and decided to establish a permanent partnership. They adopted the motto "In Unity is Strength" and worked tirelessly for the betterment of all citizens of Peoria. Their efforts greatly affected the working-class neighborhoods. ${ }^{224}$

The Federation found their initiatives often uncovered unexpected issues. For example, within a month of starting her duties as truancy officer, Mrs. Stouffer discovered that children did not attend school because they lacked suitable clothing and she alerted the Federation of the need. Women answered her call by not only donating items but also by forming a sub-group, the Dorcas committee, to sew, mend, and store children's clothing. The work of the committee grew tremendously and within a few years the scope of the work expanded to teaching working-class mothers how to mend and sew. Well into the 1910s, the committee annually solicited the

\footnotetext{
${ }^{222}$ Clapp, Mothers of all Children, 19. See also Flanagan Seeing with Their Hearts, for an excellent overview of the many and diverse women's clubs that emerged in this era.

${ }^{223}$ White, "History of the Peoria Women's Civic Federation 1905-1955," introduction.

${ }^{224}$ White, "History of the Peoria Women's Civic Federation 1905-1955," 2.
} 
Federation for sewing machines, bolts of fabric, and used garments in order to keep up with the demand for its services. By 1911, the Dorcas committee had so many mothers coming to sew and mend garments that they sought help from the Catholic Women's League Day Nursery to care for working-class children while their mothers worked on the clothing for their families. The organization helped 1,447 women and 819 children with 269 of those women helping to sew or mend garments in 1917. The organization bragged that 1,600 women attended sewing classes in 1919 whereas only 65 women attended classes just four years earlier. ${ }^{225}$

Successful club initiatives such as the appointment of a truancy officer and the Dorcas committee solidified collaboration among the diverse women's groups and demonstrated the extensive power they garnered through collaboration. Female reformers realized a united partnership of many smaller groups accomplished much more than each group individually. By working through the alliances, women turned their concerns into public causes that sometimes operated behind political systems and sometimes utilized them to effect change.

For example, the Dorcas committee worked with a settlement house program on South Washington Street, the Neighborhood House, located in the heart of one of the poorest workingclass neighborhoods. Their efforts helped secure resources such as sewing machines for the people who needed their services the most. By 1908, the Dorcas committee reported that many working-class mothers came to the Neighborhood House to sew and mend clothes for their families. One history of the committee notes that "One hardworking mother said she did enjoy going to the Neighborhood House; to her those afternoons were like a visit; most of the week she was at the washtub; now she had one pleasant afternoon to look forward to. Another said: I have learned so many things here. It has been a great help to me."226 The work of this committee went

\footnotetext{
${ }^{225}$ White, "History of the Peoria Women's Civic Federation 1905-1955," 6.

${ }^{226}$ White, "History of the Peoria Women's Civic Federation 1905-1955," 6.
} 
beyond just supplying clothing for needy children; their efforts helped to keep them in school.

The committee provided a social outlet for working-class women, boosted their self-esteem by allowing them to work for the items they received instead of getting a handout, and taught domestic skills to those who did not know how to sew or mend.

Members of the Peoria Women's Civic Federation also involved themselves in establishing juvenile court resources. They utilized the court system to effect changes for the common good. Peoria created a juvenile court in 1901 that resembled Chicago's, which was the nation's first juvenile court when it opened in 1899. Women from prominent progressive reform organizations aided and advised both juvenile court judges in Chicago and Peoria. The opening of juvenile courts in Illinois demonstrated the recognition by the Illinois state government of its duty toward children but also new progressive attitude about children. ${ }^{227}$ In her study of the juvenile courts and the Progressives in Chicago, historian Victoria Getis found that many Illinois reformers believed that while heredity could play a role in delinquency, environment was a much greater factor. ${ }^{228}$ They believed the unfavorable conditions for physical health and moral development in the city produced delinquents. Children were products of poverty, neglect, and sometimes the victims of poor parenting. Reformers reasoned that if a poor environment caused delinquency then changing the environment should reduce it. The concern over juvenile delinquency was not unique to Illinois and by 1909, twenty-two other states passed laws establishing juvenile courts, many of them modeled after Illinois' courts. Female reformers embracing "maternalist" rhetoric and new methods of dealing with problem children led the initiatives for change in many states. ${ }^{229}$

\footnotetext{
${ }^{227}$ Clapp, Mothers of all Children, 19. See also Steven Schlossman, Transforming Juvenile Justice Reform Ideals and Institutional Realities, 1825-1920, (DeKalb: Northern Illinois University Press, 2005).

${ }^{228}$ Victoria Getis, The Juvenile Court and the Progressives, (Urbana: University of Illinois Press, 2000), 18.

${ }^{229}$ Clapp, Mothers of all Children, 77.
} 
Progressives in Peoria worked to create better environments to curtail juvenile delinquency. One such effort was the establishment of a detention home. Shortly after the establishment of the Federation in 1905, Judge Siemmons, Peoria's juvenile court judge, addressed the women and attributed the success of the juvenile court to the efforts of the volunteer work of Federation members. He urged the organization to work towards a parental and detention home to assist with the growing problem of juvenile delinquency. He claimed that the current efforts of the Lutheran Home, Home of the Good Shepherd, and the Home of the Friendless were simply not enough. ${ }^{230}$

Young juvenile delinquents such as Ruth Nelson provided an example for Judge Siemmons as to why Peoria needed a detention home. By 1906, sixteen-year-old Ruth Nelson, an orphan who had been arrested several times for theft, had been in and out of the Catholicmanaged Home of the Good Shepherd so many times that the Sisters of the institution refused to take her back because of the demoralizing influence she reportedly had on the other residents. The lack of space at the State Training School for Girls in Geneva, Illinois, put Nelson at risk of incarceration in the Peoria Workhouse. The Police Matron knew this incarceration would push the girl into contact with immoral adults who would further corrupt her. ${ }^{231}$ As a result, women from the Federation spearheaded an effort to obtain a detention home, which included drafting legislation to secure public funding. The Truant Officer and Federation member, Mrs. Fritts, accompanied Illinois Senator Mr. McRoberts to present the legislation to the governor of Illinois in 1907. She relayed to Governor Deneen the work conducted in Peoria in regards to juvenile delinquency and illustrated how that work affected every county in Illinois. That day Deneen

\footnotetext{
${ }^{230}$ White, "History of the Peoria Women's Civic Federation 1905-1955," 8-9.

231 "It's a Shame Says the Matron No Local Detention Home To Which Ruth Nelson Can Be Sent Home at Geneva is Filled and the Home of the Good Shepherd Will Not Take Her," Peoria Journal, June 28, 1906, evening edition.
} 
signed the bill, which provided public funding for the home. The local efforts of the PWCF to secure a detention home determined statewide legislation.

In this way, the Federation used its collective power to effect political action. Fritts, as well as other progressives, believed that preventive and pre-court work deterred juvenile delinquency. In 1909, she collaborated with other Federation women to rent a former saloon to house "an office, a free Club room, and a milk depot, in a neighborhood where so many of our families are located." ${ }^{232}$ The establishment became known as the American Club and when its doors opened in April 1909, 162 boys were waiting to be admitted. By July 175 girls were welcomed to the club. The American Club provided a place for the children to bathe, taught classes on various subjects, organized indoor games and entertainments, and planned outings for study and fun. All these activities kept children out of trouble and adequately supervised. The American Club in Peoria illustrates the progressive ideal that effecting change to a poor environment was a useful tool in deterring juvenile delinquency.

The Dorcas Committee and the American Club were projects undertaken by the PWCF that were operated and funded without the need for municipal action. Clubwomen initiatives met with public approval as long as they did not call for legislation, infringe upon the rights of men, or require municipal funds. ${ }^{233}$ Yet, the attempts of the Peoria Women's Civic Federation to secure a suitable holding cell in the city jail and Night Matron paid from the city budget provide good examples of the resistance clubwomen faced. In 1913, upon the recommendation of Police Matron Mayall, the Federation began work to secure a Night Matron as well as a room to place female detainees. City officials claimed no space or funding existed for these initiatives but Federation women continued in their efforts. They eventually found three rooms next to the

\footnotetext{
${ }^{232}$ White, "History of the Peoria Women's Civic Federation 1905-1955," 16.

${ }^{233}$ Sherman, "The Womens Club in the Middle Western States," 31.
} 
Police Matron's office, and furnished them to meet the prisoners' needs. For years following this, local officials ignored Federation contentions that all other cities the size of Peoria had Night Matrons and that conditions in Peoria desperately called for one. The city finally appointed a Night Matron in 1919 after six years of the Federation's lobbying efforts. The need for a Night Matron and space for female inmates did not affect the lives of Federation women personally yet they tried to make a difference in the lives of less fortunate women who did not have a voice of their own.

\section{RESCUE HOMES}

The Peoria Women's Civic Federation was one type of association that worked to alleviate the suffering of working-class families in Peoria. Institutions such as the Florence Crittenton Home, Home of the Good Shepherd, and Evangelical Lutheran Kinderfreund Society Home were well-known rescue homes that operated in many parts of the country. These rescue homes created a safe haven for children and young women who were facing difficulties and needed the familial relationships of a home. ${ }^{234}$ Branches of these homes opened in Peoria in the late nineteenth century, showing the strength of female moral reform in the area. Female reformers' ideas about motherhood and reform were essential to the development and definition of progressivism. ${ }^{235}$ Rescue homes differed from reform organizations like the PWCF in terms of scope, function, and support. While members of the PWCF were upper or middle-class women who volunteered their time for the good of society championing a variety of causes, the women who managed the rescue homes considered themselves professionals, trained in rescue work and

\footnotetext{
${ }^{234}$ Katherine G. Aiken, Harnessing the Power of Motherhood: The National Florence Crittenton Mission, 1883 1925, (Knoxville: University of Tennessee Press, 1998), xvii.

235 Aiken, Harnessing the Power of Motherhood, 68.
} 
the operation of a social welfare institution. ${ }^{236}$ While the rescue homes relied on the financial and material support of civic groups like the PCWF to help them accomplish their missions, reform organizations, like the PCWF, relied on the experts in the field for information and guidance that helped them further their reform agendas. One such expert, Kate Waller Barrett, directed the National Florence Crittenton Mission for unwed mothers for many years and believed that women with training in rescue work, missionary work, and administrative duties were better able to meet the needs of the Missions' clientele. ${ }^{237}$ This approach to skilled and knowledgeable rescue work set the rescue institutions apart from the volunteer organizations like the PCWF.

Many faith-based rescue missions in Peoria followed a casework approach to professional social work. Casework helped social workers identify environmental causes of poverty or abuse through their collection of demographic and social information about clients, such as where one lived, what neighbors interacted with them, and how they earned a living. ${ }^{238}$ Casework also helped agencies such as the Illinois Board of State Commissioners of Public Charities inspect organizations that offered aid to children; for example in the case of the State Industrial School for Girls in Peoria, casework evidence revealed abuse and neglect, which led to the School's closure.

The Florence Crittenton Home (FCH), a maternity home for unwed mothers, represents an important example of a faith-based mission whose staff employed casework. FCH began in Peoria as the Home of Blessing in 1892 during the national maternity home movement, which looked to rescue, protect, and redeem unwed mothers and out-of-wedlock children. ${ }^{239}$ The Home

\footnotetext{
${ }^{236}$ Aiken, Harnessing the Power of Motherhood, 45. Barrett opened the National Florence Crittenton Mission Training School for Christian Workers in 1898 and guided the curriculum and operation. The first two directors of Peoria's Florence Crittenton Home were trained at the National Training School.

237 Aiken, Harnessing the Power of Motherhood, 68.

${ }^{238}$ Gordon, Heroes of Their Own Lives, 62.

${ }^{239}$ Otto Wilson, Fifty Years' Work With Girls, 1883-1933 A Story of the Florence Crittenton Homes, (Alexandria, Virginia: The National Florence Crittenton Mission, 1933), 394. "The work of building and furnishing the Home of
} 
struggled for the first ten years of operation despite the hard work of the loyal women who championed the cause. It received little support from the community, as many did not see the value in assisting the class of girls who entered the Home. This lack of support was not unique to Peoria. That same year, Kate Weller Barrett had experienced opposition when attempting to open a rescue home in Atlanta. ${ }^{240}$ Lacking court and community support, Peoria's Home of Blessing had no legal standing to insist young mothers remain in the Home for reformation. Shortly after the turn of the century, the national reformer Charles Crittenton spent two weeks in Peoria where he examined the dismal situation as the Home board of directors had given up and planned to turn it into an orphanage. After much coercing Crittenton convinced the Home of Blessing's board to turn the premises over to him to establish a FCH for unwed mothers.

Community members, clubs, churches, and several charity organizations donated goods and provisions for twenty-nine rooms. ${ }^{241}$ The first several matrons of the Home were trained at the Florence Crittenton Home in Washington D.C., and committees were established to oversee the needs of the nursery, the house and grounds, furnishings, devotions, education, finances, clothing, and provisions. The success of the Home can be traced to the dozens of devoted community volunteers who donated their time, talents, and financial resources. Capable directors, a well-trained staff, and leadership from the National headquarters also contributed to its longevity and success.

\footnotetext{
Blessing was sponsored by a group of women who realized the great need of an institution to care for the many young girls and women who were being ruined through the influence of evil companions in the sixty wine rooms and three hundred saloons in Peoria." See also Regina G. Kunzel, Fallen Women, Problem Girls Unmarried Mothers and the Professionalism of Social Work 1890-1945, (New Haven: Yale University Press, 1993), 9-10. 240 Aiken, Harnessing the Power of Motherhood, 37.

${ }^{241}$ Wilson, Fifty Years' Work With Girls, 395-396. The following people and organizations donated cribs and other furniture as well as food: Arcadia Avenue Presbyterian, Bethel Presbyterian, Grace Presbyterian Sunday School, Madison Avenue Methodist Church, Young Ladies Crittenton Circle, Home of Blessing Board. Mrs. Cook, Dr. Buckey, Mrs. C.E. Anthony, and Mr. and Mrs. Rockhold, each furnished one room and Mrs. Julia Procter White furnished two.
} 
In 1910, The Home assisted twenty-seven mothers and thirty children. Examination of the finances for that year illustrates the support the organization received from the community. Over sixty percent of the financial support of the Home came from church or private donations, and fundraisers headed by community volunteers such as bake sales, rummage sales, and a bazaar, as well as excursions on the Illinois River. ${ }^{242}$ When compared to the finances of the Home of the Good Shepherd and the Evangelical Lutheran Kinderfreund Society Home, it is clear that the Florence Crittenton Home depended on the generosity and support of the community. Both the Home of the Good Shepherd and the Evangelical Lutheran Kinderfreund Society Home also received some private support, but were forced to take out loans in 1910 to help support their institutions. ${ }^{243}$

The mission of Evangelical Lutheran Kinderfreund Society Home of Peoria was to receive and care for neglected and dependent children and to find good family homes for them. According to the Commissioners of the Public Charities of Illinois, the institution had a good system of home placing, which included inspections of the home before and after placement as well as requiring recommendations from the church pastor and two elders before placing a child in a home. ${ }^{244}$ The facility, built and equipped by a private donor, was donated to the association for use as an orphanage in 1902. The institution received no state funds as the church and private donors supplied all of its needs. In 1908, the Home received a total of seventy-eight children. Forty-seven were placed in homes, five were returned to friends, three died, and the rest remained in the home. ${ }^{245}$ The inspection of the home before and after placement of the child as

\footnotetext{
242 State of Illinois Board of Administration First Annual Report January 1, 1910 to September 30, 1910 (Springfield: Illinois State Journal Co, State Printers, 1911), 936.

${ }^{243}$ State of Illinois Board of Administration First Annual Report, 935, 941.

${ }^{244}$ Twentieth Biennial Report of the Board of State Commissioners of Public Charities of the State of Illinois, (Springfield: Illinois State Journal Co. State Printers, 1909), 241.

${ }^{245}$ Twentieth Biennial Report of the Board of State Commissioners of Public Charities of the State of Illinois, 270.
} 
well as the systematic gathering of recommendations further illustrates the progressive attitude of Peoria citizens. The attempts to place children in a good family home reflects the maternalistic sensitivity that reformers possessed. Growing up in a healthy home was important to the development of a child.

The Women's Christian Home Mission of Peoria directed the Home for the Friendless, an institution designed to take in impoverished children. The Home received both public and private contributions and, in 1909, voluntary contributions from women in Peoria provided for the maintenance of nine of the fifty-seven residents. ${ }^{246}$ The Home depended on some municipal funds for support but parents also paid the Home for boarding their children. Impoverished parents often placed their children in homes such as the Home for the Friendless because they could not afford to care for them. ${ }^{247}$ Sometimes the placing out was a short-term solution so a single mother could work and other times the children were given up permanently for adoption or were abandoned.

The Good Shepherd Home (GSH), a private reformatory operated by the Catholic Church, aimed to protect young girls from evil actions and people, and to reform those women who had strayed from a moral path. An international institution by the 1880 s, the Peoria home was established in 1891 and assisted white girls and women. ${ }^{248}$ Anyone except for "Negroes," pregnant girls, "epileptics," or "feeble-minded" individuals would receive care. ${ }^{249}$ In 1908, the facility housed both a department for dependent children (twenty-seven) and a reformatory for

\footnotetext{
${ }^{246}$ Twenty-first Fractional Biennial Report of the Board of State Commissioners of Public Charities of the State of Illinois, (Springfield: Illinois State Journal Co. State Printers, 1911), 373.

${ }^{247}$ Gordon, Heroes of Their Own Lives, 106.

${ }^{248}$ Wood, The Freedom of the Streets, 190.

${ }^{249}$ No author, "The Home of the Good Shepherd," Typed script, Vertical File, Local History and Genealogy

Collection, Peoria Public Library, 113.
} 
girls (eighty-five girls). Revenue came from voluntary contributions and some municipal funds for county wards. ${ }^{250}$

County courts sent many girls defined as delinquent to the GSH in hope of reforming them. The Home was an alternative to state institutions such as the State Training School for Girls in Geneva, Illinois. Use of private reformatories such as GSH gave Peoria county courts an option for correcting the behaviors that marked girls as potential prostitutes, even though they may not have been convicted of a crime. ${ }^{251}$ Much like practices at the State Training School, new inmates to the GSH were tested and treated for venereal diseases. ${ }^{252}$ GSH staff preferred to keep girls from one to four years, but many remained longer. Internees lived in dormitories equipped with laundry facilities and sewing rooms, and they received a secular education, religious training, and guidance toward "true womanhood." ${ }^{253}$ Commissioners of the Public Charities of Illinois reported in 1909 that the facilities were modern with excellent sanitary conditions, clean, well-lit and ventilated dormitories, and inmates were provided good wholesome food. ${ }^{254}$ The Home of the Good Shepherd created a surrogate family for its residents that embodied all the elements that middle-class reformers deemed important.

The State Industrial School for Girls in Peoria was the opposite of the GSH in that Commissioners of the Public Charities of Illinois investigated the Industrial School stemming from charges made by Mrs. G.W.H. Gilbert, a citizen of Peoria. In 1906, Commissioners charged that the inmates of the institution received inadequate and poor quality of food, clothing, and hygiene resources, endured cruel punishments, received poor schooling and no moral training,

\footnotetext{
${ }^{250}$ Twentieth Biennial Report of the Board of State Commissioners of Public Charities of the State of Illinois, 244.

251 Wood, The Freedom of the Streets, 188.

252 "The Home of the Good Shepherd" WPA, 114.

253 "The Home of the Good Shepherd" WPA, 113.

${ }^{254}$ Twentieth Biennial Report of the Board of State Commissioners of Public Charities of the State of Illinois, 243.
} 
and work expectations were too hard and not age appropriate. Gilbert further charged that the secretary of the school mishandled funds and the institution housed residents who were outside the scope of the school's mission. The State Commissioner, Mrs. Clara Bourland, and Charles Virden, the State Agent for Visitation of Children, made a thorough investigation of the books, documents, and physical surroundings of the School and found evidence supporting the accusations. Their investigation led to the permanent closure of the institution. ${ }^{255}$ The professionalization of social work during the Progressive Era aided in the gathering of evidence against the women who ran the State Industrial School in Peoria and allowed the state childprotection agent to quickly end the abuse.

\section{YOUNG WOMEN'S CHRISTIAN ASSOCIATION}

The Young Women's Christian Association (Y.W.C.A.), the largest organization formed to help "women adrift", was one of many organizations that acknowledged the ill effects of urbanization on families and whose volunteers labored to make a difference in the lives of working-class women, children, and young adults. ${ }^{256}$ They viewed their work as an extension of their natural domestic mission as homemakers, wives, and mothers. The association's handbook, written in 1914, explained the need for women's involvement in social affairs.

Does the mother of a family desire to have her children well taught, or the school to which she sends them secure from disease, or the streets along which they walk clean and safe; does she expect the clothes they wear to be made and sold in sanitary surroundings, or the food they buy to be pure - then must the domain of her housekeeping responsibilities be extended beyond her own walls. It is true that women of strong personality in every generation have given time to exceptional tasks in community and national life, but this generation makes claim upon the ordinary woman for a share in the home-making cares of society. ${ }^{257}$

\footnotetext{
${ }^{255}$ Twentieth Biennial Report of the Board of State Commissioners of Public Charities of the State of Illinois, 251255.

${ }^{256}$ Meyerowitz, Women Adrift, 46.

${ }^{257}$ The Handbook of the Young Womens Christian Association Movement, 1.
} 
The Y.W.C.A. proclaimed the development of Christian character as its primary objective, and officials looked to help improve the poor living conditions of young women as an element of this mission. ${ }^{258}$ Many Y.W.C.A. middle-class reformers worried over the loss of sexual purity among young women in general, and even though many of their programs provided relief from the effects of poverty, they ultimately wished to preserve the chastity of unmarried working-class women. ${ }^{259}$ They hoped to eliminate some of the factors that caused women to turn to immoral means to earn money, and hoped to provide material assistance. They reasoned that if wage-earning women had a roof over their heads, were supported emotionally, intellectually, physically and spiritually, and granted wholesome entertainment and social outlets then their virginity would stay intact until they wed.

The Y.W.C.A. recognized that the twentieth century woman differed from women of earlier years and focused on the needs of wage-earning women such as protection from the effects of poverty, which included starvation, lack of shelter, warmth, and sexual immorality. The nineteenth century woman needed to be a good cook and seamstress to be a good homemaker but the twentieth century woman needed additional skills to be able to function independently. The organization strove to provide this protection by matching women with jobs, providing training and educational opportunities, supervision and moral training, offering affordable nutritious food, locating suitable housing, and ensuring safety from predators who might trick them into an immoral lifestyle. ${ }^{260}$ It also acted as a modern employment bureau by guiding girls and women into possible permanent jobs that matched their abilities. By keeping records of the girls and women they helped, the Association gathered facts for industrial training,

\footnotetext{
${ }^{258}$ The Handbook of the Young Womens Christian Association Movement, 8.

${ }^{259}$ Meyerowitz, Women Adrift, 48.

260 The Handbook of the Young Womens Christian Association Movement, 31.
} 
legislative action, and social understanding of needs. ${ }^{261}$ In 1916, the Peoria Y.W.C.A. received 169 applications for employment, 243 calls from employers and home keepers, and placed 114 girls in positions. ${ }^{262}$ The Y.W.C.A. employment bureau tended to place women in jobs that were an extension of the home - such as nursing, domestic servants, governesses, and seamstressesbut starting around 1916, the organization included clerical work. ${ }^{263}$ The organization's acceptance of clerical work for women reflects the transformation of clerking from a job preserved for men to one now suitable for women. The employment bureau hoped to stimulate a girl's ambition to do her best work, to rise as high as she could in her chosen profession, and to make the most of herself as an individual and member of society.

Even though the Y.W.C.A recognized the emergence of the young "business woman," leaders claimed the majority of female breadwinners were in either unskilled occupations or doing unskilled work, which meant low wages and a low standard of living. ${ }^{264}$ The Y.W.C.A. handbook noted, "Though capable, many of them, of work requiring higher skill, they are victims of conditions, driven by poverty and inexperienced into work that brings neither present reward nor hope for the future." 265 The Association offered classes to women for two reasons: first, to train women that would lead to better paid positions in stenography and typewriting; and second, to stimulate women mentally, since many occupations demanded physical strength but little intellectual energy. The vision of the educational department remained fixed on gendered

\footnotetext{
261 The Handbook of the Young Womens Christian Association Movement, 59.

262 "The Business Department," The Index of the Young Women's Christian Association 20, no. 1 (February 1 , 1916): 2.

${ }^{263}$ Fine, The Souls of the Skyscraper, 131.

${ }^{264}$ According to Lisa Fine in The Souls of the Skyscraper "Starting in 1917, the National Board of the Young Women's Christian Association (YWCA) began acknowledging the need to direct attention and services to the business woman . . . Through business and professional women's organizations, the girl reserve clubs, the YWCA attempted to incorporate the young business girl into the life of the association and to foster values of sorority and Christian service," 183.

265 The Handbook of the Young Womens Christian Association Movement, 56.
} 
lessons as they primarily offered courses in storytelling, first aid, beauty, and domestic functions such as sewing. Mrs. Bennett, the department chairperson in 1912, noted that young women employed during the day found it difficult to attend classes at night but emphasized the knowledge and skills they gained from the classes worth their time. ${ }^{266}$

The Y.W.C.A. also pioneered efforts in directing attention and services to the business woman. ${ }^{267}$ Starting in the 1910 s, the national board recognized the number of business women who held Y.W.C.A. memberships and encouraged their participation in the association. The national Y.W.C.A. board attempted to connect working-women and religion, uplift workingwomen, and implant a strong middle-class sense of morality. ${ }^{268}$

The main concern of the Y.W.C.A., however, was to instill good Christian character into future mothers. To this end, the association took on the task of moral training for its members. This included sermons or guest lecturers on morality and intimate conversations between reformers and association members. ${ }^{269}$ The religious work department of the Peoria Association hosted Bible study classes aimed at bringing young women to a deeper knowledge of the Christian faith. It held Vespers services each Sunday afternoon followed by a social tea. These activities provided a social outlet as well as training in morality. The Peoria Association also offered physical education, social activities, a variety of clubs, and a summer camp all intended to build up the Christian character and womanly virtues. The Peoria Y.W.C.A. created an extension department to bring the Y.W.C.A. to several workplaces that employed young

\footnotetext{
266 Mrs. C.A. Bennett, "Educational Committee” The Index 17, no 7-8 (May and June, 1912): 1.

${ }^{267}$ Fine, The Souls of the Skyscraper, 183.

268 The Handbook of the Young Womens Christian Association Movement, 15. "The women in industry are crying out against injustice, are demanding improved working conditions, shorter hours, a living wage. Through long travail of spirit they have been learning the significant truth that no woman can avail alone, that all must work unitedly for the common good. And back of all their endeavor is a deepening, if sometimes unconscious, sense of the futility of material prosperity unillumined by a spiritual ideal that transcends the world of things."

${ }^{269}$ Meyerowitz, Women Adrift, 80.
} 
women. ${ }^{270} \mathrm{~A}$ variety of activities occurred during the meetings such as dancing and cooking classes, Bible studies, travel, health, and religious talks, stories, games, and parties. All had the intent of developing the girls physically, intellectually, socially, and spiritually.

The Y.W.C.A. embraced its duty to feed "the ever-growing army of young women workers - its (the nation's) future mothers - living and working away from home." ${ }^{271}$ It claimed that the average working life of a wage-earning girl was five to seven years before marriage and during those years, lack of suitable food impaired their physical condition. The Y.W.C.A. national board referred to this as "the eating problem" and hoped to help secure the future of the nation and the middle-class home by feeding nutritious food to its future mothers. ${ }^{272}$ This fear of not having healthy mothers to raise wholesome children stemmed from middle-class anxiety over the decline of the traditional family life. The increase in divorce and desertion as well as the increase in single, female-headed households threatened the sphere of influence that middle-class women exercised over the home. In order to protect their household structure, middle-class mothers targeted future mothers who lacked familial support and provided them custodial resources such as daily meals. ${ }^{273}$ From 1911 through 1916, the Peoria Y.W.C.A. cafeteria served an average of 42,000 meals annually, 3,500 monthly, and 140 daily. ${ }^{274}$ Lunch and suppers were served daily at low prices with the majority of customers served over the noon hour. Leaders believed by charging women a low price for meals instead of just handing it out, they could teach

\footnotetext{
270 The department held weekly meetings at the Larkin Company office, the Overall Manufacturing Company, Lewis Cigar factory, and the Boss Manufacturing Company. Occasional meetings were held at the Onken and Planck laundries, and the Thomas and Clark Cracker Company.

${ }^{271}$ The Handbook of the Young Womens Christian Association Movement, 49.

272 The Handbook of the Young Womens Christian Association Movement, 49.

${ }^{273}$ Meyerowitz, Women Adrift, 52.

${ }^{274}$ Ledgers of the Y.W.C A. cafeteria department 1911, 1912, 1913, 1913 and "Cafeteria Report", The Index 20, no 1 (February, 1916): 3.
} 
them the importance of investing their money in nutritious food so that they could not only feel like they were independent but also be more useful citizens.

One of the main objectives of the national Y.W.C.A. board was to help women find acceptable shelter. In Peoria, the local Y located suitable and affordable accommodations for 140 girls in 1916. ${ }^{275}$ Finding housing proved difficult in Peoria due to the lack of boarding houses in certain areas. For example, Miss Ora Phillips wrote to the Y.W.C.A. for information on room and board after securing a job at the Holt Manufacturing company. The Y.W.C.A. secretary informed Miss Phillips that finding a good room in a respectable place in East Peoria would be impossible, since the Holt Company was located across the Illinois River and far from the cluster of boarding houses used by most single women. ${ }^{276}$ If Phillips chose to live in that affordable and multi-use district, she would need to secure daily transportation to the Holt Company, an added expense.

Communications like these were common and included women with dependents. Single, working-women struggled to find adequate housing in Peoria, but a woman with dependents experienced even more difficulty because boarding homes did not accept children. Mrs. Leana Baker from Wapella, Illinois, wrote to the Y.W.C.A. seeking assistance to find housing for her and her children ages fifteen, eleven, six, and one year. Baker, a laundress, sought two furnished rooms on a lower level so that she could do laundry. The Y.W.C.A. worked diligently for the family, but they admitted that property owners were unwilling to rent to families with children because land ladies made more money renting to multiple single women. ${ }^{277}$

\footnotetext{
275 “General Report," The Index 20, no 1 (February, 1916): 2. Strange, Girl Problem, 57. The Toronto, Canada, Y.W.C.A. established supervised boarding houses for young women in need of shelter and many other local Y.W.C.A. facilities accommodated a residence hall.

${ }^{276}$ Letter from the Peoria Y.W.C.A. to Miss Ora E. Phillips May 20, 1920

${ }^{277}$ Letter from the Peoria Y.W.C.A. to Leana Baker July 1, 1920.
} 
Another resource housed in the Y was the Travelers' Aid Society, a nation-wide movement that worked to protect travelers regardless of age, religion, nationality, or sex. ${ }^{278}$ While the Travelers' Aid department of the Y.W.C.A. of Chicago was organized in 1888, Peoria did not have a Traveler's Aid until the end of $1910 .{ }^{279}$ There were fourteen railroad terminals in Peoria, eleven of which were part of a national rail system making travel to and from Peoria convenient for people on day excursions, those seeking to relocate to a city with a multitude of employment opportunities, or convention goers from all parts of the country. ${ }^{280}$ It also made a convenient location for nefarious persons to meet unsuspecting and naïve women who were alone and new to the city. Agents and runners of brothels frequented docks and train stations offering assistance to unsophisticated girls and women who traveled alone. The Y.W.C.A. perceived "women adrift" through Victorian conceptions of feminine weakness and innocence, which led them to place the blame for her fall from innocence on male predators. ${ }^{281}$ The Travelers' Aid Society of Chicago and Illinois provided the following example of why aids were so important: "The lonesomeness of the first home-leaving, the anxiety of the first city visit, the strangeness and uncertainty of the future, the desire for companionship - these make easy the introduction of dangerous acquaintances." 282 Some railroad officials realized the potential danger for lone female travelers, and the Peoria \& Pekin Union railway agreed to pay for a portion of the Peoria aid's salary. The national Y.W.C.A. organization boasted that the placement of Travelers' Aids resulted in the near disappearance of agents and runners for disreputable houses

\footnotetext{
${ }^{278}$ Everett L. Meservey, The Travelers' Aid Society of Chicago and Illinois: Second Annual Report, (Chicago: Travelers Aid Society, 1916), 4.

279 "Will Place Woman at Union Station," Peoria Journal, October 12, 1910, evening edition.

${ }^{280}$ Rice, Peoria City and County Illinois A Record of Settlement, Organization, Progress, and Achievement, Vol I (Chicago: The S.J. Clarke Publishing Company, 1912), 139-140.

${ }^{281}$ Meyerowitz, Women Adrift, 50.

${ }^{282}$ Meservey, The Travelers' Aid Society of Chicago and Illinois, 7.
} 
from the train stations and docks thus keeping unsuspecting girls from falling into the underworld.

Peoria's Union Station Aid worked from 3 o'clock in the afternoon until midnight "to take in charge any strange girls who may drift into the city and know not which way to turn."283 During her first fifteen days of work, the aid helped fifty-five girls in a variety of ways, including directing them to the Y.W.C.A or other destinations. She assisted many travelers who were sick, blind, deaf, or old and provided oversight to multiple young girls. ${ }^{284}$ Within the first year, aids at the Peoria station helped over fifteen hundred travelers. Their responsibility grew annually and in 1912 alone, they had helped nearly three thousand travelers at the station. ${ }^{285}$ While the majority of this help was in providing directions and information, aids provided special oversight to over 200 girls who traveled alone.

The work performed by the aids was a daily asset to the community as it kept many women and children safe during moments of unforeseen crisis. Mrs. Flora Reagan, the Peoria Travelers' Aid in 1912, noted she directed a mother to the Home of the Friendless, showed a few confused young girls how to navigate the train station, helped a mother with her young children, and procured a hotel room for another mother and her two small children when they missed their train. The aid transported a little girl to the home of her sister and purchased a ticket for a young girl who had lost her pocketbook and ticket and had no means to get to her final destination. ${ }^{286}$ Travelers' aids believed it was their duty to see these women and girls to safety. ${ }^{287}$

\footnotetext{
283 "Will Place Woman at Union Station," Peoria Journal

284 Flora B. Reagan, "Report of Y.W.C.A. Traveler's Aid” December 1 1910, Y.W.C.A. Collection, Peoria Historical Society/Bradly University Special Collection Center.

${ }^{285}$ Flora B. Reagan, “Report of Y.W.C.A. Traveler's Aid” May 1 1913, Y.W.C.A. Collection, Peoria Historical Society/Bradly University Special Collection Center.

286 “The Travelers' Aid Department," The Index 17, no 7-8 (May and June, 1912): 6.

${ }^{287}$ Meyerowitz, Women Adrift, 52.
} 
The Y.W.C.A was proactive in its efforts to support the physical and moral well-being of women as is illustrated by the many services the Association provided. The Peoria Y.W.C.A general secretary, Miss Elizabeth McKenzie, received letters every day from girls contemplating migrating to Peoria to find work and provided a few reasons for working-girls problems. She claimed that girls from the country were unskilled and could only obtain low paying positions that did not pay enough to live on. Moreover, the girls working in Peoria factories were subjected to the advances of older men and were left unsupervised in the company of male co-workers. Her experiences in working with young girls at the Y.W.C.A led Miss McKenzie to doubt the success of reforming the wayward. ${ }^{288}$

\section{STATE INITIATIVES}

Privately funded rescue homes and institutions such as the Y.W.C.A. recognized the obstacles working-class girls faced as did civic officials who supported statewide initiatives that benefited wage-earning women. Many progressive solutions for assisting wage-earning women took the form of statewide labor regulations meant to benefit the working-class women of Peoria. The regulation of labor is an important part of the Progressive Era and to the understanding of the plight of wage-earning women. Labor legislation covered a wide range of issues and was controversial in nature. It could be protective; providing safe and clean working conditions, establishing a minimum wage, shortening labor hours, or minimizing health hazards or it could be restrictive; aimed at excluding workers from certain kinds of jobs. Historians have assessed how restrictive laws applied mostly to women whose work was limited by the duties they were

\footnotetext{
${ }^{288}$ Edith Gilmore, "Girl Unfitted For City Life Is Never Safe What to Do with Country Lass Is Bring Problem of Y.W.C.A. Miss M'Kenzie Talks New Girls in Some Stores Get only \$4 a Week; Can't Live On It. \$10 Is Safe Minimum," Herold Transcript Monthly, July 1, 1914. She claimed the girls believed their lives at home were boring and they wanted "gayety and money to buy fine clothes, and they don't stop to think of their fitness for money making. They lose out in their positions, are too proud to go back home, and then - well, we all know the countless tragedies that are going on constantly under our very eyes, and which it is hard to see any way to prevent."
} 
allowed to perform in many industries. Middle-class views of women's proper roles, as homemakers were often evident in labor legislation or in court cases involving controversial labor laws. Labor legislation ran the gamut from targeting single occupations, genders, or ages, to being all-inclusive. It often pitted working women against men, employers against employees, and manufacturers against labor unions. ${ }^{289}$

The effects of poverty due to the inability of women to earn a living wage was a popular theme among progressive reformers, and legislators worked to enact laws to protect wageearning women. Labor laws that reinforced the maternal function of women were proposed and debated repeatedly in Illinois. This type of protective behavior is illustrated by the work of the Illinois Senate Vice Commission. While the main intent of the investigation was to devise solutions to eradicate the white slave industry, the findings of the commission are important to understanding the lives of working-class women in Peoria and the progressive reformers who helped them.

On his first day as President of the Illinois Senate in February 1913, Lieutenant Governor Barratt O'Hara pledged to the Illinois Senate to devote his full energies and efforts to what he believed was Illinois' chief problem: 'that problem that has to do with the chastity of our women and the sanctity of our homes." ${ }^{\prime 290}$ O'Hara referred to the issue of prostitution and particularly the so-called white slave industry. The senators voted unanimously to join a nation-wide movement to end white slave trafficking and established a committee of five to investigate white slavery and the condition of women throughout the state. ${ }^{291}$

\footnotetext{
${ }^{289}$ Kessler-Harris, Out to Work, 180-181.

${ }^{290}$ Report of the Senate Vice Committee, 13.

${ }^{291}$ Report of the Senate Vice Committee, 14. Beginning in February 1913 and continuing for two years the committee heard testimony from a variety of sources including past and present prostitutes, madams, "employers, social workers, public officials, preachers, reformers, dance hall proprietors, educators, labor leaders, physicians," and others regarding the perils of womanhood. The committee consulted delegates from the International Purity
} 
The Illinois Senate joined the national movement to suppress prostitution and related vices in 1913 but the regulation of urban vice had been a national issue since the $1890 \mathrm{~s} .{ }^{292}$ The antivice campaign, while national in scope, was fought at the local level. Peoria reformers looked for guidance concerning its red-light district and relied heavily on state and national vice commission reports. The effort to reduce vice was a two-way street between the state and the city. The data collected from the investigation of Peoria by the Illinois Senate Vice Commission assisted in drawing conclusions about how to combat prostitution across the state. Peoria then used those statewide recommendations to make informed decisions about the local community. The Illinois Senate Vice Commission determined improvements in the wages and working conditions of working-class women were crucial to the reduction of prostitution in cities like Peoria.

The Committee published their findings and recommendations in a 1916 report. ${ }^{293}$ After careful consideration of all materials examined, the committee reported several motives behind the entrance into prostitution, all linked to poor economic conditions, and concluded poverty was both directly and indirectly the principal cause of prostitution. ${ }^{294}$ They found this fact to be

\footnotetext{
Congress, vice committees in other states, and even prominent leaders in the nation's capital to glean a national viewpoint of the problem. The search for a national perspective supplemented the testimony heard in the Illinois cities of Chicago, Galesburg, Joliet, Quincy, East St. Louis, Bloomington, Rock Island, Alton, Springfield, and Peoria and helped the committee determine which issues were local, regional, or national in scope. It also helped the committee understand the success and failures of endeavors executed in other states and nationally.

${ }^{292}$ Mara L. Keire, For Business \& Pleasure, 2. For more information on the national vice campaign, see Ruth Rosen, The Lost Sisterhood Prostitution in America 1900-1918 (Baltimore: John Hopkins University Press, 1982). See also Brian Donovan, White Slave Crusades: Race, Gender, and Anti-Vice Activism, 1887-1917, (Urbana: University of Illinois Press, 2006).

${ }^{293}$ Report of the Senate Vice Committee, 4. The committee gathered an exhaustive amount of data which included: analysis of current state laws regarding the issues in question, stenographic reports of the proceedings of public meetings and testimonies conducted by the commission, summaries of investigation of general vice conditions in selected Illinois cities, analysis of unsolicited correspondence from all over the world, recommendations of other vice committees, statistics on the prevalence of and remedies for venereal diseases, reports on investigations of vice in foreign countries, scholarly research on the correlation between low wages and prostitution, and the support of the Woman's Legislative Congress.

${ }^{294}$ Report of the Senate Vice Committee, 23. "This committee was unable to learn of a single prostitute, in any city in Illinois visited, or in which its investigators operated, who had come from a home of even modest prosperity.
} 
universally true among examinations of individuals and the findings of other commissions. Reformers believed in a direct correlation between morality and poverty, so they fought to raise women's wages, lower the hours they spent in labor outside the home, and improve general working conditions such as safety and comfort in factories as a remedy to these problems.

The committee contended that girls entered prostitution due to their inability to earn a living wage on their own, the need to supplement parents' or husbands' meager income, the unregulated condition of domestic employment, and lack of regulation in the general employment of girls. ${ }^{295}$ Some women could not survive on their meager wages, and either prostituted themselves occasionally or engaged in prostitution as their sole means of income. Moreover, young wage-earners were most often undereducated, insufficiently protected, and separated from proper family influences that might have kept them from falling into prostitution. They faced poor working conditions, which included sexual advances from employers, long hours, lack of social interaction, and a constant reminder of inferiority all of which contributed to their desire to escape from starvation wage employment.

To repair this moral damage, the committee targeted improving employment conditions and wages by enacting a minimum wage law for any woman or minor. ${ }^{296}$ The committee called for the improvement of the hours of labor, working conditions, and vocational training opportunities for girls. Providing a means for girls to gain skills that led to proper employment gave them alternative options to prostitution as many women who operated in the vice district were unskilled and untrained. Reformers believed that permanent reformation was possible with the lessoning of economic pressure secured through schools that prepared women to earn an

\footnotetext{
Women do not seek lives of prostitution, except under economic pressure, or economic expediency, or under the handicap of moral and mental defects resulting from previous family economic conditions."

${ }^{295}$ Report of the Senate Vice Committee, 28-49.

${ }^{296}$ Report of the Senate Vice Committee, 127.
} 
adequate wage and by keeping the fallen women away from old associations long enough to change their influence. ${ }^{297}$

To arrive at these conclusions and recommendations the committee relied on the competencies of people intimately knowledgeable of the causes and results of impoverished women. One such group of expertise, the Women's Legislative Congress, was a cluster of several hundred women representing prominent organizations and groups in the field of social welfare work. ${ }^{298}$ Multiple women from Peoria were delegates to the conference and their knowledge about conditions in Peoria helped shape the recommendations the women suggested. The Congress proposed a minimum wage for women and minors, limited working hours for women in certain industries, a required day of rest in all occupations, elimination of girls under eighteen from street trades, and prohibition of minors from employment in messenger service during certain hours. Notable educational recommendations included raising the compulsory school age from fourteen to sixteen and the prohibition of the employment of children under the age of sixteen without a special certificate. The social recommendations, perhaps the most noteworthy contributions of the Congress, illustrate the emphasis that reformers put on traditional roles as homemaker and parent. These recommendations included better provisions for the support of wives and children by husbands and fathers, penalties for non-support and abandonment, better provisions for the support of illegitimate children, and raising the age of consent from sixteen to eighteen. ${ }^{299}$

\footnotetext{
${ }^{297}$ Report of the Senate Vice Committee, 54.

${ }^{298}$ Report of the Senate Vice Committee, 935. After the conference the women formed a permanent organization, the Woman's Legislative Congress, and announced they would meet annually preceding the opening of the regular legislative session to formulate recommendations and would continually advise male legislators on issues relating to womanhood in Illinois

${ }^{299}$ Report of the Senate Vice Committee, 936-937.
} 
Despite being a decidedly crucial measure in raising wage-earning women out of poverty, the campaign to raise the minimum wage for women was a long hard battle in Illinois. Progressive legislators who pushed for higher wages for women repeatedly met with opposition. Minimum-wage bills were introduced into the Illinois General Assembly every year from 1913 through 1921, expect for 1919 but no action was ever taken on the measures. ${ }^{300}$ The first Illinois minimum wage law for women was not enacted until 1933 despite efforts of the Progress party, the Women's Trade Union League, and the National Consumers' League. Repeated attempts to pass a minimum wage law for women failed due to the unfavorable U.S. Supreme Court decision in Adkins vs. Children's Hospital and because of opposition from the Associated Employers of Illinois and the Illinois Manufacturers' Association. ${ }^{301}$ Also, the Women's Trade Union League decided to focus their efforts on reducing the length of the workday for women and gave up on attempts to raise the minimum wage. This focus of efforts created longstanding conflict with the manufactures of the state.

Reduction in the workday for women was another fundamental recommendation of the commission that took many years to accomplish. ${ }^{302}$ The length of the workday had been a source of concern for reformers for many years prior to the Illinois Vice Commission investigation. Progressive reformers recognized that long work hours and especially overtime kept mothers

\footnotetext{
${ }^{300}$ Earl Beckner, A History of Labor Legislation in Illinois, (Chicago: University of Chicago Press, 1929), 131.

${ }^{301}$ Beckner, A History of Labor Legislation in Illinois, 131-132. Supreme Court justices ruled in Adkins $v$ Children's Hospital (1923) that a law authorizing a wage board to ascertain and fix adequate wages for female employees in the District of Columbia infringed upon Fifth Amendment rights. According to the majority ruling, the employer and employee had a constitutional right to contract in whatever way the pleased and the Wage Board was an unjustified interference of the freedom of the contract.

${ }^{302}$ Beckner, A History of Labor Legislation in Illinois, 188-189. The 1893 Sweatshop Act prohibited the employment of any female in any factory or workshop for more than eight hours a day. Illinois Supreme Court ruled the act was unconstitutional in 1895 on several grounds. The Court found it was biased and discriminatory in character. It ruled the act placed arbitrary restrictions upon the fundamental right of the citizen to control her own time and skills. It also determined that the act intervened in matters that the employer and employee were competent to negotiate with one another.
} 
from taking care of their homes and caring for their children. Long, fatiguing workdays led to physical and mental exhaustion for many working women. The variability of seasonal work, which required overtime in peak seasons and layoffs in slack seasons, caused feelings of insecurity. Most working women simply accepted the long day and low pay because they needed the job and feared that opposition could end in unemployment. ${ }^{303}$

In 1908, several female trade unions prepared a bill similar to a law in Oregon mandating a ten-hour workday for women in certain occupations. The ten-hour law passed much to the dismay of The Illinois Manufacturers' Association who vehemently opposed it. ${ }^{304}$ A Cook County judge declared the law unconstitutional stating it condemned women to dependence, opposed the policy of the state to raise women to an equal basis with men, and prohibited women from their constitutional right of making contracts. This declaration caused a great disturbance throughout Illinois as the press, religious organizations, labor unions, trade unions, and public organizations such as the Illinois State Conference of Charities and the Illinois Federation of Women's clubs publically opposed the ruling. Louis Brandeis, a national figure who was instrumental in the passage of the Oregon law, argued before the Illinois Supreme Court defending the constitutionality of the Illinois ten-hour law. His remarks in both Oregon and Illinois focused on women as the weaker sex and their maternal duties. ${ }^{305}$

The Illinois Supreme Court upheld the constitutionality of the law, adding that most Americans understood the appropriateness of a ten-hour workday for women. The court further declared the physical composition of a woman, her maternal functions, including the rearing and

\footnotetext{
${ }^{303}$ Tentler, Wage-Earning Women, 53-56.

${ }^{304}$ Beckner, A History of Labor Legislation in Illinois, 196. The bill singled out manufacturing, mercantile, or mechanical establishment, laundry, hotel or restaurant work. It included penalties for violation and gave enforcement power to the State Department of Factory Inspection. Immediately after the law went into effect, a manufacturer in Chicago filed an injunction to stop enforcement of the law claiming it interfered with the freedom of female workers, prevented them from earning a living wage, and impeded the conduct of business.

${ }^{305}$ Kessler-Harris, Out to Work, 187.
} 
education of children, and maintenance of the home all required a limitation on the number of hours women spent in labor outside of the home. ${ }^{306}$ The ruling reiterated the middle-class notion that working outside of the home interfered with women's true domestic mission.

Periodically from 1911 through the 1930s, legislative skirmishes occurred surrounding the ten-hour law but neither side was successful in amending it. In 1917, the governor of Illinois created the Illinois Industrial Survey commission and charged it with studying all the industries in Illinois, which employed women, focusing on their hours of labor, and the effect of the hours on the health of female employees. ${ }^{307}$ The commission recommended that Illinois adopt an eighthour workday in industries covered by the 1911 ten-hour law. It called for further study of women employed in night work, regulation of lunch breaks, rest periods, and other similar conditions. A proposed bill, supported by the governor, did not pass and the standard workday was not reduced until the 1938 Fair Labor Standards Act.

Protective labor laws aimed at helping wage-earning women did not always produce the desired outcome. Employers in many industries developed tactics to dodge the limitation of workhours by stopping clocks or adding time when machinery broke down. They drove workers harder to increase productivity thus producing the same amount of goods in ten-hours that a worker would have produced in the previous eleven or twelve hour workday. Women often cooperated with employers by working longer hours or off the clock for fear of losing their jobs. ${ }^{308}$ Without the passage of a minimum wage to accompany the reduction in work hours, the income of many wage-earning women was reduced making it even harder to earn a living wage.

\footnotetext{
${ }^{306}$ Beckner, A History of Labor Legislation in Illinois, 206.

${ }^{307}$ Beckner, A History of Labor Legislation in Illinois, 212. The commission was composed of employers of industry that employed women, female industrial workers, persons interested in social problems, and persons in the medical field.

${ }^{308}$ Kessler-Harris, Out to Work, 188.
} 
Labor activists were not the only reformers interested in working conditions for women. Sherman Kingsley, superintendent of the United Charities of Chicago, addressed multiple issues affecting female workers during a lecture to a large crowd of social workers gathered in Peoria for a conference. He expounded on the Illinois protected machinery bill, legislation pending on the prohibition of night work for women and children, the appointment of women factory and medical inspectors, and called for the establishment of a wages board to regulate wages and for the appointment of a commission to study employers' liabilities laws. ${ }^{309}$

Working-class women in Peoria, like their sisters across the nation, faced many hardships due to low wages and poor working conditions. However, they did not have to face these hardships alone as progressive reformers, social agencies, and labor activists rallied to invoke legislative and social changes that uplifted wage earning women and their dependents. Reformers labored to repair the deteriorating American home and reclaim the moral superiority of motherhood.

\footnotetext{
${ }^{309}$ Sherman C. Kingsley, "Social Legislation," Twenty-first Fractional Biennial Report of the Board of State Commissioners of Public Charities of the State of Illinois, 551. The protected machinery bill provided for the fencing, covering, or guarding of all machinery, conveying power, hoistways, etc. It provided seats for female employees, for air space, ventilation, and equable temperature, and against excessive humidity. It provided for exhaust devices, proper drainage and disposition of refuse, ample lighting and floor space, adequate and separate dressing rooms, toilet rooms and lavatories, and the report of accidents or injuries involving fifteen days cessation of labor.
} 


\section{CONCLUSION}

This thesis adds to the current historiography of wage earning women at the turn of the twentieth century through its compilation of information on a group of women in a city that no one has yet studied. When I started examining the holdings of the Peoria Public Library's Local History and Genealogy Room and the Cullum-Davis Library's Special Collections I expected to find only information on the young wage-earning women adrift, as has traditionally been the focus of studies on working women in this era. Instead, my research led me to a much bigger picture as I uncovered the lives of working mothers in the city and the concerns they generated for city leaders, social workers, and reformers. As I unpacked the unprocessed boxes of the Y.W.C.A. collection at the Cullum-Davis Library I was astounded to find letters from working mothers looking to Peoria's Y.W.C.A. for support and advise on housing and employment in the city. I had expected to see correspondence from young, single girls, not mothers. I collected and analyzed information on Peoria that currently does not exist in secondary literature.

The plight of wage earning women in Peoria at the turn of the twentieth century fully represented the challenges of working women both regionally and nationally. While Peoria was not a metropolis like New York or Chicago, I found working women in Peoria faced afflictions—low wages, long working hours, and the difficulties of independence-similar to those acknowledged in studies of wage earning women in larger cities. The concerns of Peoria's reformers, social workers, and municipal leaders emphasized local matters and my research revealed these mirrored state and national concerns. However, Peoria's reformers faced unique circumstances due to the large distilling and brewing industries that influenced the city. These reformers were aggressive in their efforts to alleviate the burdens of the independent wageearning women and were not content to wait to see what transpired in a larger city. This study 
demonstrates that the examination of smaller communities in addressing an alleged larger problem is valuable because it shows the depth and breadth of an issue.

Although extensive research conducted by the Illinois Senate Vice Commission and the Illinois Industrial Survey in the mid-1910s revealed causes for the difficult circumstances independent working women confronted and proposed recommendations to lessen those difficulties, little changed financially for wage earning women in Peoria for decades. In reviewing this research, experts understood that working women could not live independently on their wages and therefore many turned to prostitution to supplement their income. As is highlighted in this thesis, reformers believed that a decrease in poverty among working women benefited society in many ways. They believed the best way to accomplish this was to raise women's wages, making it possible for working women to afford descent housing, food, and clothing for themselves and their children.

My research presents why change did not immediately occur in response to the commission's findings. The early twentieth century gendered understanding that women should not be the primary breadwinner hindered change. Louis Brandeis exploited this cultural belief in Muller v Oregon when he argued that women's chief responsibility should be the care of the home and children. He argued long hours in the workforce was detrimental to those responsibilities and ultimately the good of the race. Both the U.S. and Illinois Supreme Courts validated this cultural understanding by affirming Brandeis' argument. This cultural belief is also evident among reformers in Peoria's Florence Crittenton Home, Home of the Good Shepherd, and the Y.W.C.A. Administrators of the FCH emphasized a mother's duty to her children and nurtured maternal bonds between mother and child. Girls in the care of the GSH received 
guidance toward true womanhood and the majority of classes offered at the $\mathrm{Y}$ were gendered lessons.

I argue Peoria's business owners and managers held this same cultural value but their reasons for keeping women's wages low extended beyond it. During their testimony to the Senate Vice Commission, Peoria business managers repeatedly stated they knew they did not pay women a living wage because they did not believe that most female employees did or should live independently. This illustrates the prevalence of the cultural value but in addition to this, the business managers believed raising wages or cutting hours reduced their profits. Research reveals the Illinois Manufacturers Association and similar groups repeatedly blocked legislation intended to improve wages and working conditions for women because of the anticipated financial loss.

While many women in Peoria were compelled to work outside of the home, the overwhelming message they received from society was that a job should not be their primary or permanent focus. Even the Y.W.C.A. claimed they assisted women for the few years that they lived independently in the city prior to marriage. With these barriers to success, how were working women in Peoria able to live independently? I found that for many wage earning women living independently meant accepting assistance from charitable organizations, the truancy officer, the Police Matron, applying for a mothers' pension, or by circumventing respectable assistance and supporting themselves in the vice district. This last measure was most effective for women who could not or would not get assistance through legitimate means.

While the concerns of reformers in Peoria mimicked regional and national concerns Peoria's demographics and the size of the distilling and brewing industry in Peoria created unique situations for social reformers. I found that Peoria was a wide-open city and the 
manufacture and pervasive consumption of alcohol escalated many social problems such as poverty, domestic violence, alcohol abuse, desertion, and divorce. My evidence shows that Peoria had an abundance of unmarried women who needed to work to support themselves and possibly dependents. All of these issues created chaotic and unstable homes that reformers helped in working class neighborhoods. This study exposes that Peoria's reformers and social workers were on the forefront of creating and implementing measures that attacked major social issues at the turn of the twentieth century. Even though the underlying issue of low wages was dealt with at the state level, Peoria's reformers started initiatives that provided immediate assistance to wage earning women in the working class communities. 


\section{BIBLIOGRAPHY}

$\underline{\text { Archival Sources }}$

Peoria, Illinois

Cullum-Davis Library, Special Collections Center, Library of the Peoria Historical Society

Young Women's Christian Association of Peoria Collection, Peoria Historical Society, Special Collections Center, Bradley University Library, Peoria, IL

Annual Report of the Young Women's Christian Association, 1914

Report of Traveler's Aid for Young Women's Christian Association from January 1, 1911- February 1, 1911

Report of Y.W.C.A. Travelers' Aid November 15, 1910 - November 15, 1911, typed script

Report of Y.W.C.A. Travelers' Aid from Dec. 1 to Jan 1. 1911

Report of Y.W.C.A. Travelers' Aid January 1, 1912- February 1, 1912

Report of Y.W.C.A. Travelers' Aid Jan. 1 - 1913 - - Feb. 1 - 1913

Report of Y.W.C.A. Travelers’ Aid Jan. 1 - 1914 - - Feb. 1 - 1914

The Index Vol. XVII No. 7-8 May and June 1912

The Index Vol XX No.1 February 1, 1916

Peoria, Illinois

Peoria Public Library, Local History \& Genealogy Collection

Annual Reports of the Associated Charities and Philanthropies of Peoria, 1902$1905 ; 1912$.

Constitution and By-Laws of the Women's City Club of Peoria, undated.

History of the YWCA Peoria Illinois, 1893-1967.

History of the YWCA Peoria, 1894-1974.

"Home of the Good Shepherd" 
House of Corrections Scrapbook, undated.

House of Corrections Superintendents Report, 1890-1915.

Lottmann, Mary Ellis, "Sixty-five Years of Service A History of the Peoria Women's Club," undated.

Peoria County, Illinois Corner's Records Book C, June 1897 - Feb. 1906.

Publicity Committee of the Peoria Association of Commerce, "The Great Middle West the World's Center of Production and Consumption, Peoria the Central City, 1912."

Schipper \& Block Department Store Rule Book, undated.

Traces of 100 Years of Accomplishments by the YWCA of Peoria, undated.

White, John A. Peoria City Directory 1911. Peoria: John A. White, Publisher, 1911.

White, Julia Procter, History of the 1905-1955 Peoria Women's Civic Federation, undated.

Wright, Mary Pauline, The History of Neighborhood House, undated.

Government and Organizational Documents

Department of Commerce and Labor Bureau of the Census. Thirteenth Census of the United States Taken in the Year 1910: Statistics for Illinois. Washington, D.C.: Government Printing Office, 1913.

Department of Commerce and Labor Bureau of the Census. Special Reports: Marriage and Divorce 1867-1906 Part I Summary, Laws, and Foreign Statistics. Washington, D.C.:

Government Printing Office, 1909.

Department of Commerce and Labor Bureau of the Census. Special Reports: Marriage and Divorce 1867-1906 Part II General Tables. Washington, D.C.: Government Printing Office, 1908.

Department of Commerce Bureau of the Census. Marriage and Divorce 1916. Washington, D.C.: Government Printing Office, 1919.

Illinois Board of State Commissioners of Public Charities. Twentieth Biennial Report of the Board of State Commissioners of Public Charities of the State of Illinois. Springfield: Illinois State Journal Co., 1909. 
Illinois Board of State Commissioners of Public Charities. Twenty-first Fractional Biennial Report of the Board of State Commissioners of Public Charities of the State of Illinois. Springfield: Illinois State Journal Co., 1911.

Illinois Bureau of Labor Statistics. Fourth Annual Report of the Bureau of Labor Statistics of the Illinois Free Employment Offices for the Year Ended October 1, 1902. Springfield: Phillips Bros., 1903.

Illinois Bureau of Labor Statistics. Eighth Annual Report of the Bureau of Labor Statistics of the Illinois Free Employment Offices for the Year Ended October 1, 1906. Springfield: Phillips Bros., 1907.

Illinois Bureau of Labor Statistics. Tenth Annual Report of the Bureau of Labor Statistics of the Illinois Free Employment Offices for the Year Ended September 30, 1908. Springfield: Illinois State Journal Co., 1909.

Illinois Bureau of Labor Statistics. Eleventh Annual Report of the Bureau of Labor Statistics of the Illinois Free Employment Offices for the Year Ended September 30, 1909. Springfield: Illinois State Journal Co., 1910.

Illinois Bureau of Labor Statistics. Twelfth Annual Report of the Bureau of Labor Statistics of the Illinois Free Employment Offices for the Year Ending September 30, 1910. Springfield: Illinois State Journal Co., 1911.

Illinois Bureau of Labor Statistics. Thirteenth Annual Report of the Bureau of Labor Statistics of the Illinois Free Employment Offices for the Year Ending September 30, 1911. Springfield:

Illinois State Journal Co., 1912.

Illinois Bureau of Labor Statistics. Fourteenth Annual Report of the Bureau of Labor Statistics of the Illinois Free Employment Offices for the Year Ending September 30, 1912. Springfield:

Illinois State Journal Co., 1913.

Illinois Bureau of Labor Statistics. Fifteenth Annual Report of the Bureau of Labor Statistics of the Illinois Free Employment Offices for the Year Ending September 30, 1913. Springfield:

Illinois State Journal Co., 1914.

Illinois Bureau of Labor Statistics. Seventeenth Annual Report of the Bureau of Labor Statistics of the Illinois Free Employment Offices for the Year Ending September 30, 1915. Springfield: Illinois State Journal Co., 1916.

Illinois Bureau of Labor Statistics. Eighteenth Annual Report of the Bureau of Labor Statistics of the Illinois Free Employment Offices and the Supervision of Private Employment Agencies for the Year Ending September 30, 1916. Springfield: Illinois State Journal Co., 1917. 
Illinois Congress. Senate. Report of the Senate Vice Committee Created Under the Authority of the Senate of the Forty-ninth General Assembly As A Continuation of the Committee Created Under the Authority of the Senate of the Forty-eighth General Assembly State of Illinois. $49^{\text {th }}$ Cong., Chicago: Allied Printing, 1916.

Illinois General Hospital for the Insane at Peoria. Eighth Biennial Report of the Peoria State Hospital at Peoria, Illinois June 30, 1910. Springfield: Illinois State Journal Co., 1914.

Illinois General Hospital for the Insane at Peoria. Ninth Biennial Report of the Peoria State Hospital at Peoria, Illinois July 1, 1910 to September 30, 1912. Springfield: Illinois State Journal Co., 1914.

Illinois State Training School for Girls at Geneva, Illinois. Eighth Biennial Report of the Trustees, Superintendent, and Treasurer. Springfield: Illinois State Journal Co, 1909.

Illinois State Training School for Girls at Geneva, Illinois. Ninth Biennial Report of the Managing Officer. Springfield: Illinois State Journal Co, 1911.

Illinois State Training School for Girls at Geneva, Illinois. Tenth Biennial Report. Springfield: Illinois State Journal Co, 1914.

Illinois State Training School for Girls at Geneva, Illinois. Eleventh Biennial Report. Springfield: Illinois State Journal Co, 1915.

Peoria Comptroller Report. City Comptroller's Report Statement of the Finances of the City of Peoria for the Fiscal Year Ending December 31, 1900 Together with Reports of the Various Departments. Peoria: Edward Hine \& Co., 1901.

Peoria Comptroller Report. City Comptroller's Report Statement of the Finances of the City of Peoria for the Fiscal Year Ending December 31, 1903 Together with Reports of the Various Departments. Peoria: Peoria Printing and Stationary Co., 1904.

Peoria Comptroller Report. City Comptroller's Report Statement of the Finances of the City of Peoria for the Fiscal Year Ending December 31, 1904 Together with Reports of the Various Departments. Peoria: Peoria Printing and Stationary Co., 1905.

Peoria Comptroller Report. City Comptroller's Report Statement of the Finances of the City of Peoria for the Fiscal Year Ending December 31, 1905 Together with Reports of the Various Departments. Peoria: John J. Gallagher, 1906.

Peoria Comptroller Report. City Comptroller's Report Statement of the Finances of the City of Peoria for the Fiscal Year Ending December 31, 1906 Together with Reports of the Various Departments. Peoria: John J. Gallagher, 1907. 
Peoria Comptroller Report. City Comptroller's Report Statement of the Finances of the City of Peoria for the Fiscal Year Ending December 31, 1909 Together with Reports of the Various Departments. Peoria: Brown-Williams Printing Co., 1910.

Peoria Comptroller Report. City Comptroller's Report Statement of the Finances of the City of Peoria for the Fiscal Year Ending December 31, 1910 Together with Reports of the Various Departments. Peoria: Henniges \& Co., 1911.

Peoria Comptroller Report. City Comptroller's Report Statement of the Finances of the City of Peoria for the Fiscal Year Ending December 31, 1911 Together with Reports of the Various Departments. Peoria: Henniges \& Co., 1912.

Peoria Comptroller Report. City Comptroller's Report Statement of the Finances of the City of Peoria for the Fiscal Year Ending December 31, 1912 Together with Reports of the Various Departments. Peoria: Edw. Hine \& Co., 1913.

The National Desertion Bureau. Family Desertion and Non-Support Report of the National Desertion Bureau. New York: The National Desertion Bureau, 1915.

Travelers Aid Society Illinois. The Travelers' Aid Society of Chicago and Illinois Second Annual Report. Chicago: Travelers' Aid Society, 1916.

$\underline{\text { Newspapers }}$

Peoria Journal Star

Bloomington Pantagraph

Herold Transcript Monthly

\section{$\underline{\text { Secondary Sources }}$}

Aiken, Katherine G. Harnessing the Power of Motherhood: The National Florence Crittenton Mission, 1883-1925. Knoxville: University of Tennessee Press, 1998.

Alexander, Ruth M. The Girl Problem: Female Sexual Delinquency in New York, 1900-1930. Ithaca: Cornell University Press, 1995.

Beckner, Earl R. A History of Labor Legislation in Illinois. Chicago: The University of Chicago Press, 1929.

Breines, Wini and Linda Gordon. “The New Scholarship on Family Violence." Signs 8, no. 3 (Spring 1983): 490-531.

Broder, Sherri. Tramps, Unfit Mothers, and Neglected Children Negotiating the Family in Late Nineteenth-Century Philadelphia. Philadelphia: University of Pennsylvania Press, 2002. 
Bruce, Andrew Alexander. "The Illinois Ten-Hour Labor Law for Women.” Michigan Law Review 8, no. 1 (November 1909): 1-24.

Butler, Anne M. Gendered Justice in the American West: Women Prisoners in Men's Penitentiaries. Urbana: University of Chicago Press, 1997.

Cahen, Alfred. Statistical Analysis of American Divorce, (New York: Columbia University Press, 1932).

Clapp, Elizabeth J. Mothers of All Children: Women Reformers and the Rise of Juvenile Courts in Progressive Era America. University Park: The Pennsylvania State University Press, 1998.

Ciani, Kyle. "Hidden Laborers: Female Day Workers in Detroit, 1870-1920." Journal of the Gilded Age and Progressive Era 4, no. 1 (January 2005): 23-51.

----------- "Problem Girls: Gendering Criminal Acts and Delinquent Behavior." Journal of Women's History 9, no. 3 (Autumn 1997): 203-214.

Clement, Elizabeth. Love For Sale: Courting, Treating, Prostitution in New York City, 19001945. Chapel Hill: University Of North Carolina Press, 2006.

Diffee, Christopher. "Sex and the City: The White Slavery Scare and Social Governance in the Progressive Era." American Quarterly 57, no. 2 (June 2005): 411-437.

Diner, Steven. A Very Different Age: Americans of the Progressive Era. New York: Hill and Wang, 1998.

Dodge, Mara L. Whores and Thieves of the Worst Kind: A Study of Women, Crime, and Prisons, 1835-2000. DeKalb: Northern Illinois University Press, 2002.

Donovan, Brian. White Slave Crusades: Race, Gender, and Anti-Vice Activism, 1887-1917. Urbana: University of Illinois Press, 2006.

Durst, Anne. "Of Women, by Women, and for Women: The Day Nursery Movement in the Progressive-Era United States.” Journal of Social History 39, no. 1 (Autumn 2005), 141-159.

Edwards, Rebecca. New Spirits: Americans in the Gilded Age, 1865-1909. New York: Oxford University Press, 2006.

Fine, Lisa M. The Souls of the Skyscraper: Female Clerical Workers in Chicago, 1870-1930. Philadelphia: Temple University Press, 1990.

Flanagan, Maureen A. America Reformed: Progressives and Progressivisms, 1890s-1920s. New York: Oxford University Press, 2007. 
----------- Seeing with Their Hearts: Chicago Women and the Vision of the Good City, 1871 1933. Princeton, N.J.: Princeton University Press, 2002.

Franks Peoria City Directory Vol XXIV 1905 Directory of the Citizens. Peoria: J.W. Franks \& Sons, 1906.

Getis, Victoria. The Juvenile Court and the Progressives. Urbana: University of Illinois Press, 2000.

Goldstein, Monroe M. Family Desertion and Non-Support: Report of the National Desertion Bureau Incorporated for Three Years 1912-1915. New York: National Desertion Bureau, Inc., 1915.

Gordon, Linda. Heroes of Their Own Lives: The Politics and History of Family Violence: Boston 1880-1960. New York: Penguin Books, 1988.

Pitied But Not Entitled: Single Mothers and the History of Welfare, 1890-1935. New York: The Free Press, 1994.

Goodwin, Joanne L. Gender and the Politics of Welfare Reform Mothers' Pensions in Chicago, 1911-1929. Chicago: The University of Chicago Press, 1997.

Griswold, Robert L. "Divorce and the Legal Redefinition of Victorian Manhood" in Meanings for Manhood: Constructions of Masculinity in Victorian America, edited by Mark C. Carnes and Clyde Griffen, 96-110. Chicago: University of Chicago Press, 1990.

"Law, Sex, Cruelty, and Divorce in Victorian America, 1840-1900." American Quarterly 38, no. 5 (Winter 1986): 721-745.

Haag, Pamela. "The "Ill-use of a Wife": Patterns of Working-class Violence in Domestic and Public New York City, 1860-1880.” Journal of Social History 25, no 3 (Spring 1992): 447-477.

Hennigan, Peter C. "Property War: Prostitution, Red-Light Districts, and the Transformation of Public Nuisance Law in the Progressive Era." Yale Journal of Law \& the Humanities 16, (2004): 123-198.

Hewitt, Nancy A. Southern Discomfort: Women's Activism in Tampa, Florida, 1880s-1920s. Urbana: University of Illinois Press, 2001.

Huckelbridge, Dane. Bourbon: A History of the American Spirit. New York: William Morrow, an imprint of HarperCollins Publishers, 2014.

Karibo, Holly M. Sin City North: Sex, Drugs, and Citizenship in the Detroit-Windsor Borderland. Chapel Hill: The University of North Carolina Press, 2015. 
Katzman, David M. Seven Days a Week: Women and Domestic Service in Industrializing America. Urbana: University of Illinois Press, 1978.

Keire, Mara L. For Business \& Pleasure: Red-Light Districts and the Regulation of Vice in the United States, 1890-1933. Baltimore: John Hopkins University Press, 2010.

------------ “The Vice Trust: A Reinterpretation of the White Slavery Scare in the United States, 1907-1917." Journal of Social History 35, no. 1 (Autumn 2001): 5-41.

Kessler-Harris, Alice. Out to Work A History of Wage-Earning Women in the United States. New York: Oxford University Press, 1982.

Kunzel, Regina G. Fallen Women, Problem Girls Unmarried Mothers and the Professionalization of Social Work 1890-1945. New Haven: Yale University Press, 1993.

Lears, T. J. Jackson. Rebirth of a Nation: The Making of Modern America, 1877-1920. New York: Harper Collins, 2009.

Leff, Mark H. "The Mothers'-Pension Movement in the Progressive Era." Social Service Review 47, no. 3 (September 1973): 397-417.

Lunbeck, Elizabeth. The Psychiatric Persuasion Knowledge, Gender, and Power in Modern America. Princeton, New Jersey: Princeton University Press, 1994.

May, Vanessa, H. Unprotected Labor: Household Workers, Politics, and Middle-class Reform in New York, 1870-1940. Chapel Hill: University of North Carolina Press, 2011.

McGerr, Michael. A Fierce Discontent: The Rise and Fall of the Progressive Movement in America, 1870-1920. New York, Free Press, 2003.

Meyerowitz, Joanne J. Women Adrift: Independent Wage Earners in Chicago, 1880-1930. Chicago: The University of Chicago Press, 1988.

Michel, Sonya. Children's Interests/Mothers' Rights: The Shaping of America's Child Care Policy. New Haven, CT: Yale University Press, 1999.

Minnick, Fred. Whiskey Women: The Untold Story of How Women Saved Bourbon, Scotch, and Irish Whiskey. Lincoln, Nebraska: Potomac Books, 2013.

Mitenbuler, Reid. Bourbon Empire: The Past and Future of America's Whiskey. New York: Viking, 2015.

Murolo, Priscilla. The Common Ground of Womanhood, Class, Gender, and Working Girls' Clubs 1884-1928. Urbana: University of Illinois Press, 1997. 
Odem, Mary E. Delinquent Daughters: Protecting and Policing Adolescent Female Sexuality in the United States, 1885 - 1920. Chapel Hill: The University of North Carolina Press, 1995.

Ogg, Bryan J. Peoria Spirits: The Story of Peoria's Brewing and Distilling Industries. Peoria: Logan Printing Company, 1996.

Parsons, Elaine Frantz. Manhood Lost: Fallen Drunkards and Redeeming Women in the Nineteenth-Century United States. Baltimore: John Hopkins University Press, 2003.

Peiss, Kathy Lee. Cheap Amusement: Working Women and Leisure in Turn-of-The Century New York. Philadelphia: Temple University Press, 1986.

Peterson, David. "Wife Beating: An American Tradition." The Journal of Interdisciplinary History 23, no 1 (Summer 1992): 97-118.

Pleck, Elizabeth H. Domestic Tyranny: The Making of American Social Policy against Family Violence from Colonial Times to the Present. New York: Oxford University Press, 1987.

Rice, James Montgomery. Peoria City and County Illinois: A Record of Settlement, Organization, Progress, and Achievement. Chicago: S.J. Clarke Publishing Company, 1912.

Rose, Elizabeth R. A Mother's Job: The History of Day Care, 1890-1960. New York: Oxford University Press, 1999.

Rosen, Ruth. The Lost Sisterhood: Prostitution in America, 1900-1918. Baltimore: The John Hopkins University Press, 1982.

Rosenzweig, Roy. Eight Hours for What We Will: Workers and Leisure in an Industrial City, 1870-1920. Cambridge: Cambridge University Press, 1983.

Schlossman, Steven L. Transforming Juvenile Justice Reform Ideals and Institutional Realities, 1825-1920. DeKalb: Northern Illinois University Press, 2005.

Sherman, Mrs. John Dickinson. "The Womens Club in the Middle Western States." The Annals of the American Academy of Political and Social Science 28, (September 1906): 29-49.

Shumsky, Neil Larry. "Tacit Acceptance: Respectable American and Segregated Prostitution, 1870-1910.” Journal of Social History 19, no 4 (Summer 1986): 665-679.

Smith-Rosenberg, Carroll. Disorderly Conduct: Visions of Gender in Victorian America. New York: Alfred A. Knopf, 1985.

Strange, Carolyn. Toronto's Girl Problem: The Perils and Pleasures of the City, 1880-1930. Toronto Ont.: University of Toronto Press, 1995. 
Tentler, Leslie Woodcock. Wage-Earning Women: Industrial Work and Family Life in the United States, 1900-1930. New York: Oxford University Press, 1979.

“The Federal Wage-Hour Law and Women Workers.” The Woman Worker 18, no. 3 (1938): 3-4.

The Handbook of the Young Womens Christian Association Movement. New York: National Board Young Womens Christian Association, 1914.

The Peorian 5. No 1. (May 1915).

The Peorian 6. No 1. (May 1916).

Trachtenberg, Alan. The Incorporation of America: Culture and Society in the Gilded Age. New York: Hill and Wang, 1982.

Wagman, Jamie Schmidt. "Women Reformers Respond during the Depression Battling St. Louis's Disease and Immorality." Journal of Urban History 35, no. 5 (July 2009): 698-717.

White's Peoria City Directory Vol XXV 1906 Directory of the Citizens. Peoria: John A White, 1906.

White's Peoria City Directory Vol XXVI 1907 Directory of the Citizens. Peoria: John A White, 1907.

White's Peoria City Directory 1911 Directory of the Citizens, Business Directory, Numerical Street Directory and an Appendix of Useful Information with Map. Peoria: John A White Publishing, 1911.

Wiebe, Robert. The Search for Order, 1877-1920. New York: Hill and Wang, 1967.

Wilson, Otto. Fifty Years' Work with Girls, 1883-1933: A Story of the Florence Crittenton Home. Alexandria, VA: The National Florence Crittenton Mission, 1933.

Wood, Sharon E. The Freedom of the Streets: Work, Citizenship, and Sexuality in a Gilded Age City. Chapel Hill: University Of North Carolina Press, 2005. 